\title{
Turkey
}

\section{Building Resilience in Turkey}

Quantifying Climate and Disaster Risks to Critical Infrastructure, Lifelines and Agriculture in Turkey: New Approaches

July 2019

URS:

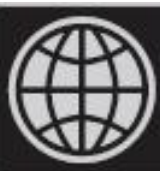




\section{DISCLAIMER}

This work is a product of the staff of The World Bank with external contributions. The findings, interpretations, and conclusions expressed in this work do not necessarily reflect the views of The World Bank, its Board of Executive Directors, or the governments they represent. The World Bank does not guarantee the accuracy of the data included in this work. The boundaries, colors, denominations, and other information shown on any map in this work do not imply any judgment on the part of The World Bank concerning the legal status of any territory or the endorsement or acceptance of such boundaries. Nothing herein shall constitute or be considered to be a limitation upon or waiver of the privileges and immunities of The World Bank, all of which are specifically reserved. The report reflects information available up to September 31, 2018.

\section{RIGHTS AND PERMISSIONS}

The material in this work is subject to copyright. Because The World Bank encourages dissemination of its knowledge, this work may be reproduced, in whole or in part, for noncommercial purposes as long as full attribution to this work is given. Any queries on rights and licenses, including subsidiary rights, should be addressed to World Bank Publications, The World Bank Group, 1818 H Street NW, Washington, DC 20433, USA; e-mail: pubrights@worldbank.org.

\section{ACKNOWLEDGEMENT OF THE PROGRAM'S CONTRIBUTION}

This report was made possible with the financial support of the Japan-World Bank Program for Mainstreaming Disaster Risk Management in Developing Countries, which is financed by the Government of Japan and receives technical support from the World Bank Tokyo Disaster Risk Management Hub 


\section{Acknowledgements}

The preparation of this report was led by Anita Ellmauer-Klambauer, Junior Professional Officer of the Urban Development and Disaster Risk Management Team- Europe and Central Asia of the World Bank.

Alanna Simpson (Senior Disaster Risk Management Specialist, World Bank), Elif Ayhan (Senior Disaster Risk Management Specialist, World Bank), Esse Ayşe Erkan Örenbaş (Disaster Risk Management Specialist, World Bank), Lisa Fonick Haworth (Office Manager, World Bank), Mustafa Uğur Alver (Operations Officer, World Bank), Pınar Arıkan (Disaster Risk Management Analyst, World Bank), Tamara Sulukhia, Turgut Erdem Ergin and Ülker Karamullaoğlu (Program Assistant, World Bank) have either supported the conduct of the risk assessment studies which this report builds on or informed this report via valuable inputs.

With strong ownership and guidance provided by beneficiary institutions namely Cukurova Development Agency (CKA), Istanbul Chamber of Industries (ISO), Tuzla Organized Industrial Zone (ITOIZ) and Izmir Development Agency (IZKA), the background work was undertaken between 2016-2018 by a team of experts from Acclimatise, Deltares and Frankfurt School of Finance and Management, supported by a World Bank Task Team.

The team particularly thanks Hülya Ulusoy, Murat Çelik, Sinem Özdemir Durmuşlar and Meltem Altınay from IZKA; Murat Torun from CKA; Erbil Büyükbay, Omer Inan and Türker Çelik from ISO, Caglar Kahraman, Gurkan Karahan from ITOIZ and the ITOIZ team , Japan International Cooperation Agency for their cooperation; and Global Facility for Disaster Reduction and Recovery which, through the Japan-World Bank Program for Mainstreaming Disaster Risk Management in Developing Countries, financed the conduct of the risk assessment studies subject to review in this report and Disaster Risk Management Hub, Tokyo for its technical assistance throughout the process. 


\section{Table of contents}

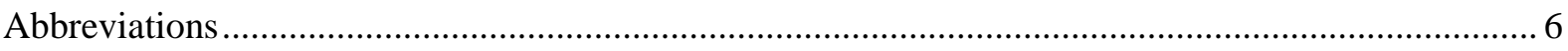

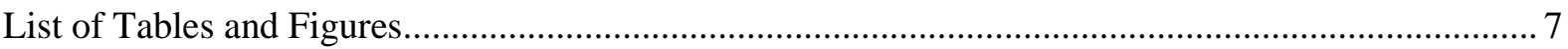

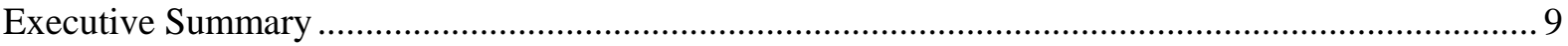

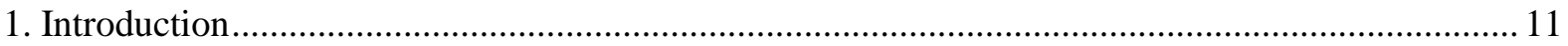

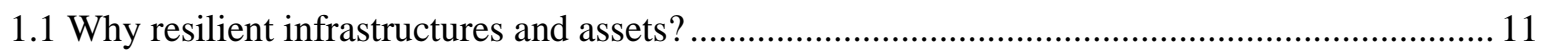

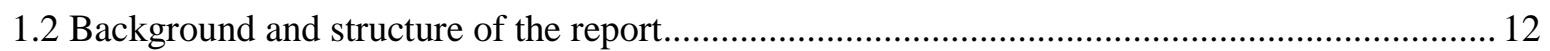

1.3 Crosscutting Areas of the Analyses and Limitations .................................................................. 14

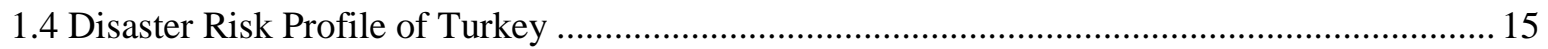

2. High-level Critical Infrastructure Risk Assessment (CIRA) .......................................................... 18

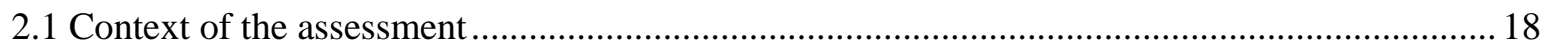

2.2 Steps and methodology of a critical infrastructure risk assessment.......................................... 18

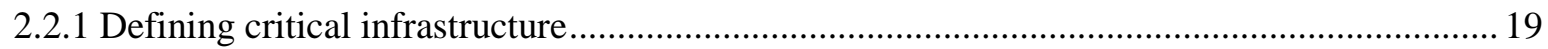

2.2.2 Identifying critical infrastructure in a given sector/region of a country ...............................20

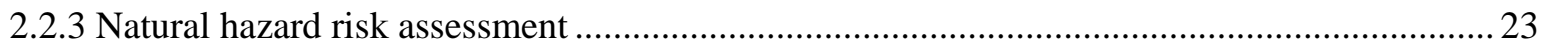

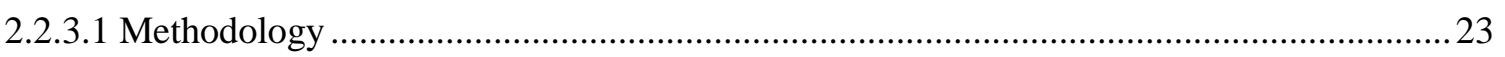

2.2.4 Analyses of current approaches to CI planning \& management in policy documents............. 28

2.2.5 Providing recommendations for improving the resilience of CI.............................................. 28

3. Key Agricultural Product Risk Assessment (KAPRA) ..................................................................... 35

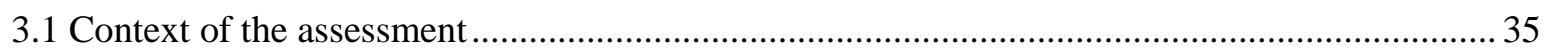

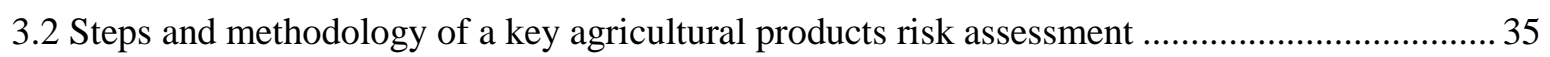

3.2.1 Framework for categorizing Key Agricultural Products........................................................... 35

3.4 Selection of Key Agricultural Products in a given region/country ........................................... 39

3.5 Assessment of Climate Change Risk for Key Agricultural Products............................................ 41

3.5.1 Assessment of Climate Change Risk …………................................................................... 41

3.5.2 Climate Change Risk Assessment for Key Agricultural Products ........................................ 44

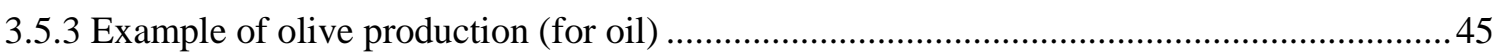

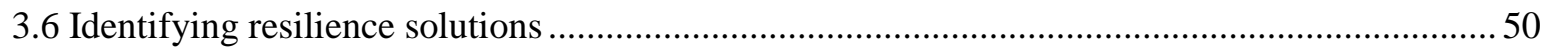

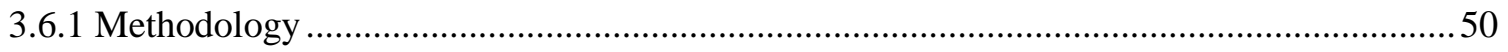

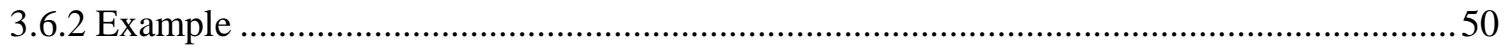

4. Lifeline Utilities Risk Assessment and Business Continuity Planning (LUBCP) ............................. 55

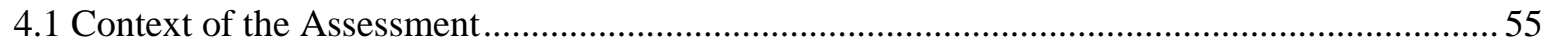

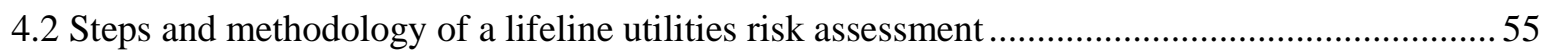




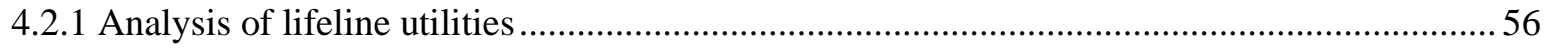

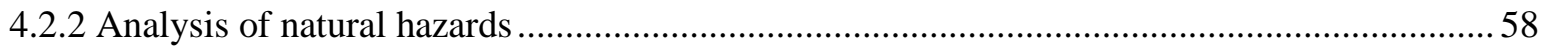

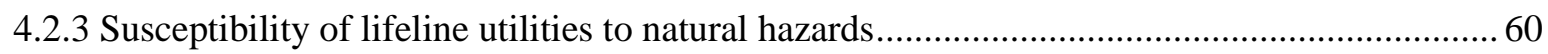

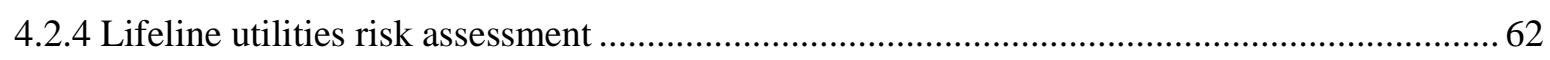

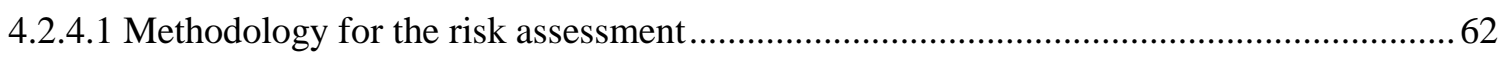

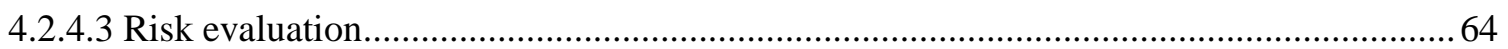

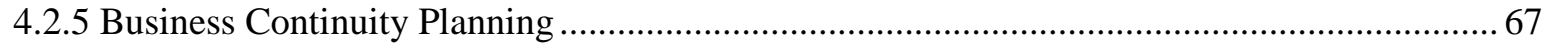

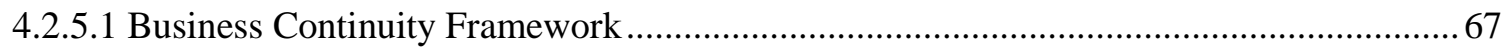

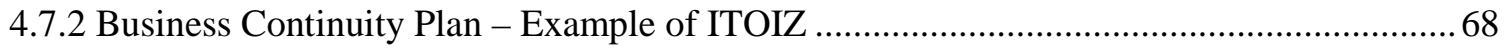

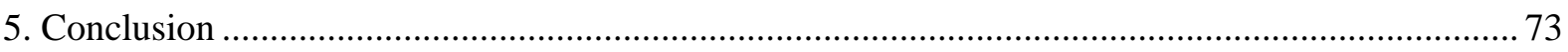

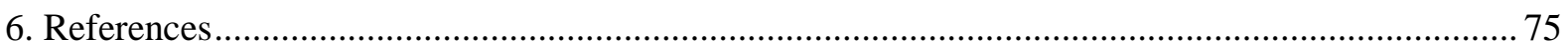




\section{Abbreviations}

AFAD

BCM

BCP

CI

CIRA

ÇKA

DLH

GCM

GDP

GVA

ICT

IPCC

ITOIZ

ISO

IZKA

KAPRA

KMRB

LU

LUBCP

MGM

OECD

RTO

SPI

TARSIM

TRY

TURKSTAT

UNFCCC

UNISDR

UK
Disaster and Emergency Management Authority

Business Continuity Management

Business Continuity Planning

Critical Infrastructure

High-level Critical Infrastructure Risk Assessment

Çukurova Development Agency

General Directorate of Railways, Harbors and Airports. Construction

General Circulation Model

Gross Domestic Product

Gross Value Added

Information and Communication Technology

Intergovernmental Panel on Climate Change

Tuzla Organized Industrialized Zone

Istanbul Chamber of Industries

Izmir Development Agency

Key Agricultural Product Risk Assessment

Kucuk Menders River Basin

Lifeline Utility

Lifeline Utilities Risk Assessment and Business Continuity Planning

Turkish State Meteorological Service

Organization for Economic Co-operation and Development

Acceptable duration of failure of each lifeline utility

Standardized Precipitation Index

Agricultural Insurance Pool

Turkish Lira

Turkish Statistical Institute

United Nations Framework Convention on Climate Change

UN International Strategy for Disaster Reduction

United Kingdom 


\section{List of Tables and Figures}

\section{List of Tables}

Table 2.1. UK Cabinet Office's categorization of infrastructure criticality scale

Table 2.2. Natural hazards experienced in Turkey used to define impact thresholds

Table 2.3. Categorization of critical infrastructure in the CIRA

Table 2.4: Dependency of Turkey’s GDP on electricity and natural gas

Table 2.5: Impact on Turkey's GDP from loss of service of selected energy infrastructure assets in Cukurova region

Table 2.6: Selected critical infrastructure in Çukurova Region

Table 2.7: Current and future levels of hazards in Cukurova region

Table 2.8 Estimated GDP losses of selected critical infrastructures in Çukurova Region

Table 2.9: Summary of the risk assessment findings for Mersin International Port

Table 2.10: Matrix of risk assessment and management measures

Table 2.11: Non-structural risk management measures

Table 2.12: Structural risk management measures for Port

Table 3.1: Indicators and their weights in the KAPRA report

Table 3.2 Ranking of agricultural products in the Kucuk Menderes River Basin

Table 3.3: Key agricultural products and their characteristic properties

Table 3.4: List of indicators

Table 3.5: Vulnerability levels which were calculated for the districts in the Kucuk Menderes Basin

Table 3.6 Effects of climate change on the olive oil production chain between 2021 and 2051

Table 3.7 Olive Oil Production Chain in the Kucuk Menderes River Basin, in case of harvest loss

Table 3.8: Resilience and Finance Solutions for Two Cases of the Production of Olive (Oil)

Table 3.9: Estimation on financing requirement of 20 Business Cases

Table 4.1: Analysis of Electricity Utilities at ITOIZ

Table 4.2 Analysis for telecommunications utility

Table 4.3 Summary of current and future hazard levels in Istanbul

Table 4.4 Hazard scenarios for Tuzla Industrialized Zone

Table 4.5 Susceptibility of lifeline utilities at ITOIZ to identified natural hazards

Table 4.6 Estimated return period (in years) for different hazard scenarios and lifeline utilities 
Table 4.9 Consequence classes in the LUBCP assessment

Table 4.10 Scoring for consequence of failure of lifeline utilities by different industries in ITOIZ

Table 4.11 Prioritization of lifeline utilities in the BCP for ITOIZ 70

Table 4.12 Precautionary and Preparedness Actions in the BCP for ITOIZ 71

$\begin{array}{ll}\text { Table 4.13 Prioritization tool for lifeline utilities } & 73\end{array}$

Table 4.14 Measures during and after an earthquake $\quad 74$

\section{List of Figures}

Figure 1.1. Natural disasters and extreme weather events 9

$\begin{array}{ll}\text { Figure 1.2 Locations of undertaken risk assessments } & 10\end{array}$

Figure 1.3 Potential Impact of Earthquakes on Provinces' GDPs in Turkey 13

Figure 1.4 Potential Impact of Floods on Provinces’ GDPs in Turkey 14

$\begin{array}{ll}\text { Figure 2.1. Interdependencies of infrastructure } & 18\end{array}$

Figure 2.2 Risk assessment methodology according to seven steps from the CIRA 23

Figure 2.3 Economic risk at Mersin International Port 28

Figure 3.1 Process of key agricultural products selection 32

Figure 3.2 Indicators for key agricultural product selection 34

Figure 3.3 Flowchart of agricultural vulnerability assessment 39

Figure 3.4 Production chain diagram for olive oil production in the Basin 43

Figure 4.1: Map with all lifeline utilities at ITOIZ 57

Figure 4.2 Completed CIrcle tool

Figure 4.3 Risk matrix for lifeline utilities at ITOIZ 66

Figure 4.4 Risk matrix for the electricity, communication and storm sewer utilities at ITOIZ 67

Figure 4.5 Risk matrix for different duration of failure of lifeline utilities at ITOIZ 68

Figure 4.6 Risk matrix for certain lifeline utilities at ITOIZ, including climate change 68

Figure 4.7 Objectives of a business continuity plan 69

$\begin{array}{ll}\text { Figure 4.8 Step-by-step plan for ITOIZ } & 72\end{array}$ 


\section{Executive Summary}

Potential impacts of natural disasters, extreme weather events and failure of climate change mitigation and adaptation continue to dominate long-term risks to economies, and societies at large. Despite the growing interest in operationalizing resilience concept, we have limited knowledge about how natural disasters and extreme weather events, either induced or exacerbated by climate change, affect critical infrastructure and assets. Investments on building resilience into these assets, services and products remains low despite evidence shows that failure to take action will result in missed opportunities to reduce long-term risks to assets, services and end-users.

To this end, Turkey Disaster Risk Management Team of the World Bank kicked off three sectoral risk assessment studies i) to elaborate and quantify structural and non-structural effects of climate change and disaster relevant to key hazards and selected sectors, ii) deliver technical assistance and resilience solutions, and iii) leverage the findings of these studies through different sources of finance and collaboration. The studies aim at presenting a way of mainstreaming disaster risk reduction and climate change adaptation into sectoral investment planning processes to increase resilience at sub-national and regional levels and demonstrate how to build resilience into location-specific critical infrastructures and services, agricultural products and lifeline utilities in Turkey.

This report is based on the following three risk assessment studies which were conducted in 2016/2018, and funded by the Global Facility for Disaster Reduction and Recovery (GFDRR) through the JapanWorld Bank Program for Mainstreaming Disaster Risk Management in Developing Countries:

- High-level Critical Infrastructure Risk Assessment in the Region of Cukurova- CIRA

- Key Agricultural Product Risk Assessment - KAPRA

- Lifeline Utilities Risk Assessment and Business Continuity Planning - LUBCP

The report discusses the methodological steps undertaken to inform the three studies and provides an overview of new approaches and insights for quantifying climate and disaster risks to critical infrastructure, lifelines and agriculture in specific regions and operational units in Turkey. The studies subject to review in this report are considered to be first of their kind in Turkey and are expected to set an example for other institutions to build capacities to deal with various adverse effects of climate change and natural disasters on their key industries, assets and services. The studies are not short of limitations, due to their pilot nature. All three studies aim to provide risk-informed strategic guidance to beneficiary counterparts, rather than detail-oriented and theoretical approaches. All three reports build on probabilistic multi-hazard risk assessments -each risk assessment comprises the following steps: (i) defining and understanding criticality of the assets/products; (ii) understanding vulnerability of critical infrastructure and key assets/products; and (iii) addressing vulnerability.

The report starts by discussing the High-level Critical Infrastructure Risk Assessment in the Region of Çukurova (CIRA). The CIRA is a study which assesses the risks posed by natural hazards to critical infrastructure assets in the Çukurova region and provides recommendations for improving resilience in critical infrastructure planning and operation. Two priority sectors were chosen for the critical infrastructure assessment: (i) energy and (ii) transport/logistics. The study was conducted in collaboration with the Cukurova Development Agency (CKA). The report starts by outlining the conceptual framework for critical infrastructure (CI) of the CIRA study and continues by showing how critical infrastructure was identified in Cukurova's energy and transport and logistics sectors. The methodology used in the CIRA takes into consideration the economic impact associated with the loss of service of a critical infrastructure asset, considers the geographical extent of the interruption and also 
reflects the cascading effects. In a next step, the report explains the methodology of the natural hazard risk assessment of the CIRA, involving development of geo-physical and climate hazard scenarios, initial screening of assets for susceptibility to hazards, collection of vulnerability and exposure data and finally implantation of the risk model in RiskAPP and assessment of the risks. The results of the natural hazard risk assessment are showcased on the basis of one critical infrastructure asset, Mersin International Port.

The report further focuses on the Key Agricultural Product Risk Assessment (KAPRA) study. The KAPRA aims to develop financial options to build resilience in Izmir's agricultural economy and competitiveness by taking into account the effects of climate change and the risks associated with it as well as the sustainability of natural resources and social dynamics. The KAPRA is one of the first in Turkey to look at the effects of climate change on agricultural outputs and to suggest solutions for economically viable climate change adaptation and resilience measures in the agricultural sector. The study was conducted in collaboration with Izmir Development Agency (IZKA). The report explains the framework which was developed in the KAPRA for the concept of "key agricultural product" and then shows how five key agricultural products were chosen for Izmir region, focusing on economic, social and ecological impacts. The report explains in a next step the methodology of the KAPRA for assessing climate change risks through the production chain, focusing on changes in the precipitation regime and in air temperatures, hailstorms, drought events and frost event. The methodology of the risk assessment is showcased with the example of olive oil production. Finally, resilience solutions and business cases which were developed in the KAPRA are presented based on two examples of olive oil production.

Lastly, the report discusses the Lifeline Utilities Risk Assessment and Business Continuity Planning (LUBCP) study. The LUBCP aims to carry out business continuity planning focusing on the lifeline utilities of Istanbul Tuzla Organized Industrial Zone (ITOIZ) to build resilience into the industry and to increase its business competitiveness. It provides understanding of risks for industries at ITOIZ due to failure of lifeline utilities, when they are affected by natural hazards. The study was conducted in collaboration with the Istanbul Chamber of Industry and the Tuzla Organized Industrialized Zone (ITOIZ) in Istanbul. The report explains how lifeline utilities at ITOIZ as well as natural hazards were analyzed in the LUBCP study. The interdependencies between different lifeline utilities are also taken into consideration. Then, the report explains the methodology for assessing lifeline utilities according to their susceptibility to natural hazards. The susceptibility analysis is further showcased on the basis of the example of electricity supply. In a next step the report goes through the methodology of the risk assessment for the identified risks of the LUBCP. The analysis comprises the likelihood of failure of lifeline utilities resulting from a natural hazard and the consequence of failure of lifeline utilities. Finally, the report also discusses the development of a Business Continuity Plan, based on the risk assessment in the KAPRA. The Business Continuity Plan includes actions to be taken before, during and after emergency situations and is based on the results of the risk assessment. Only those risks are being addressed where the combination of likelihood and consequence is so high that the risk becomes unacceptable. Among others, the Business Continuity Plan for ITOIZ includes precautionary and preparedness actions, a step-by-step plan and a prioritization tool for lifeline utilities in case of a natural hazard, which are discussed in the report.

The Report concludes with a compilation of recommendations provided by the three sectoral risk assessments while recognizing that proposed resilience solutions and implementation strategies depend very much on the specific context (national, regional and local level and/or thematic focus and operational capacities and constraints of implementing partners). 


\section{Introduction}

\subsection{Why resilient infrastructures and assets?}

As economic and human losses and damages which are attributable to natural hazards and climate change increase, there has been growing interest among international communities and policy makers in tackling the unprecedented sectoral impacts of climate change and natural disasters. According to Munich Re (2019) ${ }^{1}$, the inflation-adjusted overall disaster loss average of 2018 was above US\$140bn -when compared with the last 30 years- making 2018 among the ten costliest disaster years in terms of overall losses and was the fourth-costliest year since 1980 for the insured ones. Despite lessons learned from the past extreme weather events and natural disasters worldwide, there were 10,300 fatalities reported caused by natural disaster events worldwide in 2018, which raises concerns about the extent to which disaster risk reduction is mainstreamed across key sectors.

To better cope with the adverse impacts governments, policy makers and practitioners recognize the linkages and overlapping areas between climate change adaptation, disaster risk reduction, and sustainable development. To this end, the Sendai Framework for Disaster Risk Reduction 2015-2030 sets a global target on substantial reduction of disaster damage to critical infrastructure and disruption of basic services by 2030. The Framework also prioritizes investments in disaster risk reduction for resilience and the importance of private and public sector investments to increase resilience of all segments and sectors of the society. In addition, policy makers are requested to take necessary actions to mitigate disaster and climate risk in agricultural practices by adapting sustainable and productive agriculture systems. ${ }^{2}$ The 2030 Agenda for Sustainable Development which was adopted by all United Nations Member States in 2015, under Goal $2^{3}$, calls for immediate action to integrate disaster risk reduction and climate adaptation strategies into agriculture sector to promote resilient and agriculture production, whereas Goal 9 calls for action to build resilient and well-functioning infrastructures to increase competitiveness as well as to support economic development. ${ }^{4}$

Despite the priority actions agreed upon by the international community, analytical work underpinning to building resilience into infrastructures and critical assets has yet to meet the demand for evidencebased decision making. In line with the intensifying risks (Figure 1.1) from natural disasters and climate change, there has been an increasing interest in linking disaster risk reduction, climate change adaptation and sustainable development goals, emphasizing the need to address climate change-related loss and damage through adaptation and resilience measures. To address this gap in the Turkish context, funded by the Global Facility for Disaster Reduction and Recovery (GFDRR), the World Bank Group conducted three risk assessment studies focusing on different sectors and units overseen by nonconventional partners ${ }^{5}$ in the country. The studies subject to review in this report are considered to be the first of their kind in Turkey and - despite their limitations - are expected to set an example for other institutions to build capacities to deal with various adverse effects of climate change and natural disasters on their key industries and assets.

\footnotetext{
1 Munich $\quad$ Re, (2019), Natural Catastrophe Review 2018, https://www.munichre.com/site/corporate/get/params_E506046347_Dattachment/1707976/munichre-naturalcatastrophes-in-2018.pdf

2 https://www.unisdr.org/we/coordinate/sendai-framework

3 Goal 2: End hunger, achieve food security and improved nutrition and promote sustainable agriculture, https://sustainabledevelopment.un.org/sdg2

${ }^{4}$ Goal 9-Build resilient infrastructure, promote inclusive and sustainable industrialization and foster innovation, https://www.globalgoals.org/9-industry-innovation-and-infrastructure

${ }^{5}$ Meaning implementing partners that are not directly affiliated with the central government which in the Turkish context mostly is the conventional counterpart that benefits from Bank products and support.
} 
Figure 1.1. Natural disasters and extreme weather events

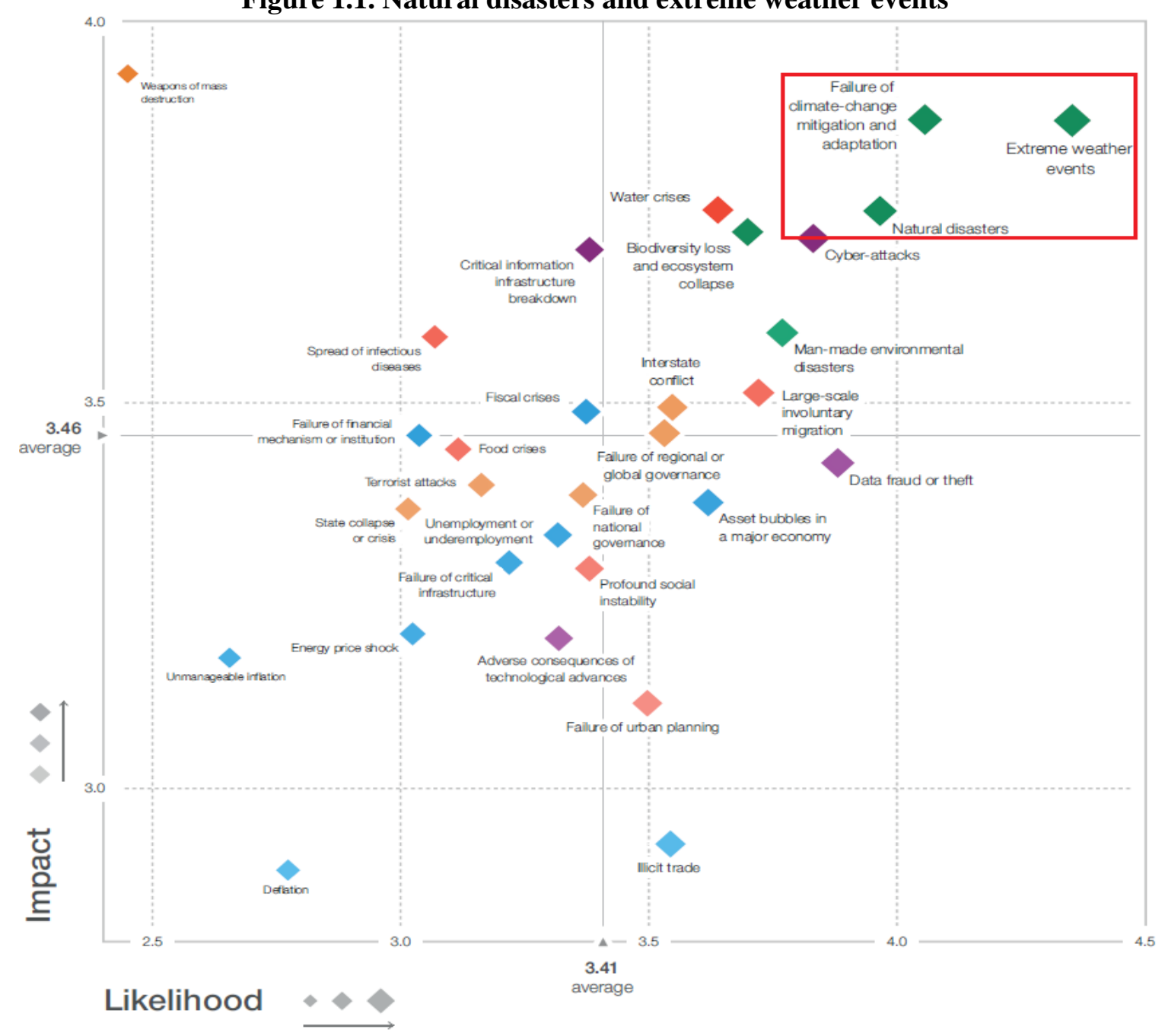

Source: The Global Risks Report, World Economic Forum (2019)

\subsection{Background and structure of the report}

The report is structured in three chapters according to the three reports. Each chapter begins with a short description of the context of the assessment and then discusses the methodology used in each report. It will not provide a full overview of the three reports, but rather focus on the sections which are relevant for a wider audience and different regions/countries. The report ends with a conclusion which summarizes the main lessons learned from the three reports.

The World Bank Group conducted the following three risk assessments focusing on different sectors in Turkey in 2016/2018, funded by the Global Facility for Disaster Reduction and Recovery (GFDRR) through the Japan-World Bank Program for Mainstreaming Disaster Risk Management in Developing Countries:

- High-level Critical Infrastructure Risk Assessment in the Region of Cukurova- CIRA (prepared by Acclimatise, final beneficiary is Cukurova Regional Development Agency)

- Key Agricultural Product Risk Assessment - KAPRA (prepared by Frankfurt School of Finance, final beneficiary is Izmir Development Agency)

- Lifeline Utilities Risk Assessment and Business Continuity Planning - LUBCP (prepared by Deltares, final beneficiary is Istanbul Chamber of Industries and Tuzla Industrialized zone at Istanbul) 


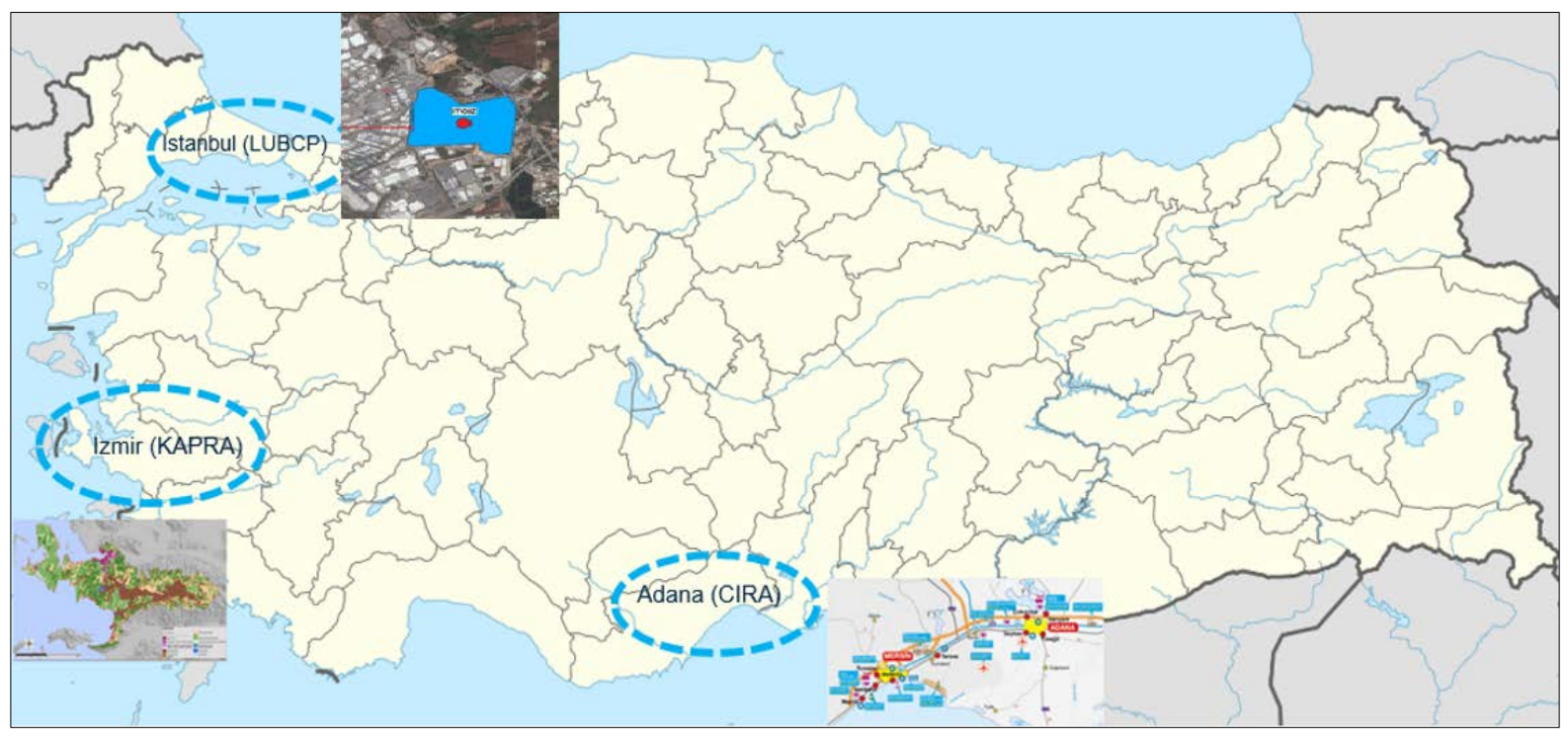

These risk assessment studies, which are first of their kind in Turkey, aim to introduce the notion of resilience of critical infrastructure and key assets and to help build the foundation for decision makers to take risk-informed decisions against the negative impact of climate change and natural hazards. While there is strong meteorological and hydrological data and climate change projections, decision makers fail to factor them into the various social, productive and infrastructure sectors' planning and to adopt the required measures.

Critical infrastructure has a fundamental role in the economic and social development of any country as well as functioning of daily life. The High-level Critical Infrastructure Risk Assessment (CIRA) in the Region of Çukurova aims to conduct a risk assessment of selected critical infrastructure (energy and logistic) to incorporate risk-informed decision-making into the regional planning process and to provide concrete structural measures for asset owners. It focusses on the development of: (i) conceptual framework for critical infrastructure, (ii) risk assessment for seismic/hydrometeorological hazards, (iii) catalog of structural resilience best practices and (iv) policy guidance for regional planning authorities to undertake risk-informed planning.

The agriculture sector is expected to be most affected by climate change which could lead to loss of livestock and food insecurity as well as loss of income and even poverty for farmers. Adaptation of new practices in production processes would help them to cope with the adverse impact of natural disasters and climate change. The aim of the Key Agricultural Product Risk Assessment - KAPRA in the Kucuk Menderes River Basin, Izmir is to conduct a risk assessment in the agriculture sector. The study encompasses four primary themes: (i) to develop a framework for the concept of "key agricultural product" and to identify existing key agricultural products in the region, (ii) to assess climate change risks in the production chain (from producer to consumer) of five selected key agricultural products, (iii) to identify resilience solutions considering economic, ecological, and social dimensions, and (iv) to develop business cases for these strategies and make recommendations regarding new funding strategies for their implementation.

Many industrial areas are located where they are prone to weather and other natural hazards. These industries can be of very different nature but all of them depend heavily on the availability of utilities like gas and electricity, information and communication technology (ICT), water, sewage and road transportation, so called lifeline utilities. For both the industrial zones and the individual industries, restoring the business and production as soon as possible after the natural disaster is of the highest 
importance. In addition, being prepared for this type of incident would provide an advantageous position to become or remain attractive for other industries to settle in their specific zone and to become more competitive against other industrial zones. The objective of the Lifeline Utility Business Continuity Planning (LUBCP) study for a pilot industrialized zone - the Organized Industrial Zone in Istanbul (TUZLA) - is to build the resilience of businesses against natural disasters and climate change by means of improving business continuity planning. It covers development of: (i) conceptual framework for business continuity planning, (ii) risk assessment for seismic/ hydrometeorological hazards, (iii) catalog of managerial resilience best practices and (iv) business continuity plan for the zone management.

\subsection{Crosscutting Areas of the Analyses and Limitations}

Understanding hazards and criticality while identifying exposure and vulnerability is the first step towards managing disaster risk. People living in disaster prone areas have assessed risks they face in various ways for centuries. Today, a range of methods can help communities, governments and nongovernmental agencies to analyze and assess risk, depending on the budget, the technical resources, and the intended purpose. By quantifying risks and anticipating the potential adverse impacts of natural hazards and extreme weather events on society and the economy, disaster and climate risk assessments can help governments, communities, and individuals to make informed decisions to manage risk. To this end, the three risk assessments undertaken by the World Bank follow the below uniform rationale to inform the implementing partners'/beneficiaries' investment planning decisions and to support better integration of efforts for disaster risk reduction.

- Understanding Criticality: Certain types of infrastructure and key assets (physical structures and products) play vital roles in underpinning resilience, economies, ecosystems, in broader terms the ways of life a society is accustomed to. These complex and interconnected systems that are inherent to day-to-day life are often threatened by service interruptions and/or failures which inform their sustainability and sometimes protection. To assess and/or analyze the risks infrastructures and key assets are exposed to, it is important to understand and define criticality. Evidence from past extreme weather events and natural disasters shows that lagging in understanding the notion of criticality, thus failing to fully capture the context to which it applies will result in missed opportunities to further reduce losses. Therefore, the entire risk assessment studies reviewed in this report ascertain a core working definition for critical infrastructures, business continuity planning and key product identification in the context of the subject case studies.

- Vulnerability of Critical Infrastructure and Key Assets: Turkey, like other middle-income countries, has a rapidly growing high-value asset base. This can create greater losses from adverse events if assets are geographically located and concentrated in exposed areas in terms of economic impact and/or competitiveness of industries. In the context of vulnerability discourse, a variety of concepts and definitions exist (for example Birkmann 2006, Thywissen 2006). It is therefore essential to clarify how vulnerability is defined within the scope of the three reports produced. Such understanding refers to the definition by the United Nations International Strategy for Disaster Reduction and is characterized by "the conditions determined by physical, social, economic, and environmental factors or processes, which increase the susceptibility of a community to the impact of "hazards.” In simpler terms, for the CIRA and LUBCP reports, the notion of vulnerability pinpoints the hazard related susceptible disruptions, failures and damages which interconnected systems and infrastructures are subject to and for the KAPRA study it entails the physical integrity of agricultural/natural assets whose productivity and quality could be subject to adverse impacts due to possible changes in operating conditions. 
- Addressing vulnerability: The impact of infrastructure/systems failure is thereby to a large extent influenced by the complexity and interdependency of networks as well as by the dependency of the population on the functioning of these services or production lines. Many developed countries and upper middle-income countries such as Turkey are often characterized by high supply levels and by business communities who are increasingly dependent on the continuity of services, infrastructure, and production of key assets. That is why all three reports build on probabilistic multi-hazard risk assessments that would help inform areas of improvement in terms of (i) service use \& governance, (ii) areas of technology improvements for lifeline utilities and supply chain resilience, and (iii) cost-efficient and risk-informed resilience solutions.

The studies subject to review are not short of limitations, due to their pilot nature. All three reports aim to provide risk-informed strategic guidance, rather than detail-oriented guidance, to beneficiary counterparts. That is why the reports predominantly relied on readily available, second hand data and desktop review. In all three reports, this shortcoming was mitigated through close consultation with central and local authorities, public agencies, academia, the private sector and the civil society, allowing the authors and the Bank to better triangulate data and induce stakeholder buy-in.

\subsection{Disaster Risk Profile of Turkey}

This section provides some background on Turkey's disaster risk profile. Turkey is among the most exposed countries to disaster risk in the world due to its tectonic, seismic, topographic and climactic characteristics. Of these risks, seismic risk is the most critical, as Turkey experiences on average one earthquake with a magnitude of 5-6 every year. In terms of exposure, 95\% of its territory, $70 \%$ of its population and $76 \%$ of its industrial facilities are located in first- and second-degree seismic risk zones. Among the variety of natural hazards faced by the country, earthquakes induced by the North Anatolian fault claimed the highest number of lives and economic loss with approximately 90,000 fatalities in numerous earthquakes since 1900, a total affected population of 7 million, and direct losses of US\$ 50 billion (Erdik, 2013). The North Anatolian microplate, which moves at a speed of 2-3cm per year westward, forms a transform fault. The geological situation in this respect is very similar to the U.S. San Andreas Fault. A portion of the northern edge of the Anatolian microplate is stuck in Asia and there hooked on the North Anatolian Fault. Preventing a continuous movement, this caused not quite as frequent, but therefore much stronger quakes in the country (GeoMaps, 2011). About half the casualties were due to two earthquakes on the North Anatolian Fault in 1939 and 1999.

The annual average population effected by earthquakes in Turkey is about 1 million and the annual affected GDP is US \$ 10 billion. The annual average of fatalities and capital losses caused by earthquakes are about 1,000 and about US \$ 2 billion, respectively. The fatalities and capital losses caused by more intense, less frequent events can be substantially larger than the annual averages. For example, an earthquake with a 0.4 percent annual probability of occurrence (a 250-year return period) is estimated to cause about 80,000 fatalities and $8 \%$ of GDP, in other words US \$ 60 billion capital loss in the country (GFDRR, 2016 - Figure 1.2).

With 18 million inhabitants, Istanbul is not only the most populated province, but also the financial, cultural and industrial center of the country, accounting for $28 \%$ of the country's GDP, generating 38 $\%$ of the national industrial output and $44 \%$ of its tax income. Another modelling study on Istanbul indicates that an Mw7.25 earthquake on the North Anatolian Fault is expected to heavily damage or destroy 2 to $4 \%$ of buildings in the city. Between 400,000 and 800,000 housing units would become uninhabitable, while 30,000 to 60,000 deaths and injuries are expected. Direct economic losses from 
building damage are estimated at US\$ 11 billion, with total economic losses of US\$ 40 billion (Demircioglu, 2011).

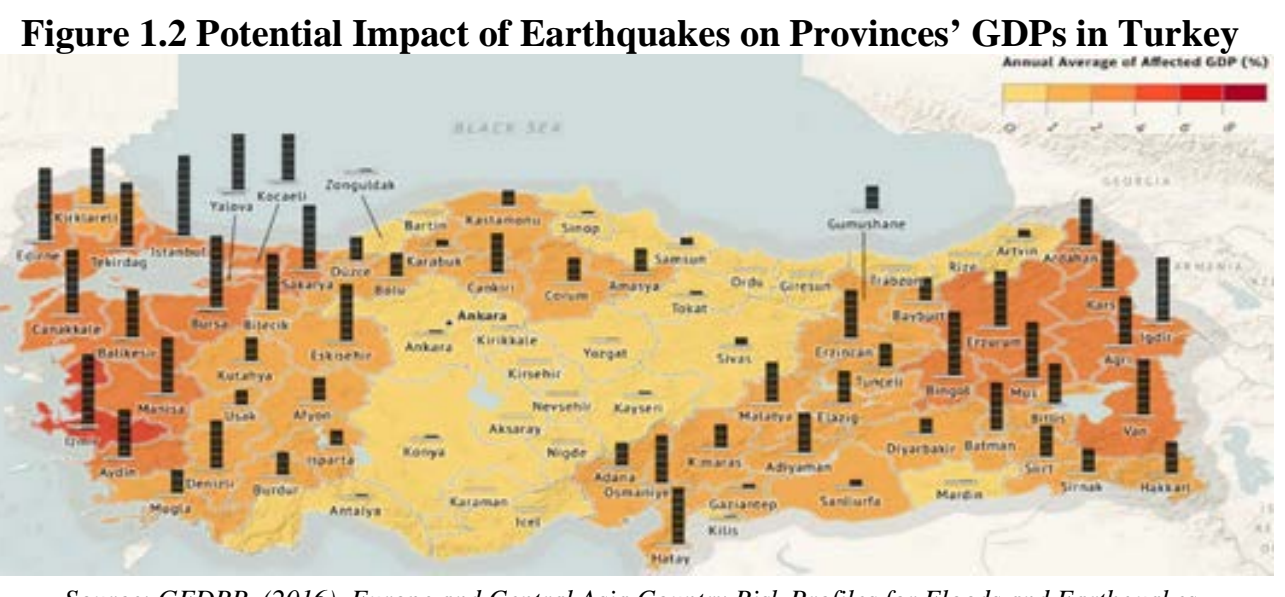

Source: GFDRR, (2016), Europe and Central Asia Country Risk Profiles for Floods and Earthquakes

Figure 1.3. Potential Impact of Floods on Provinces’ GDPs in Turkey

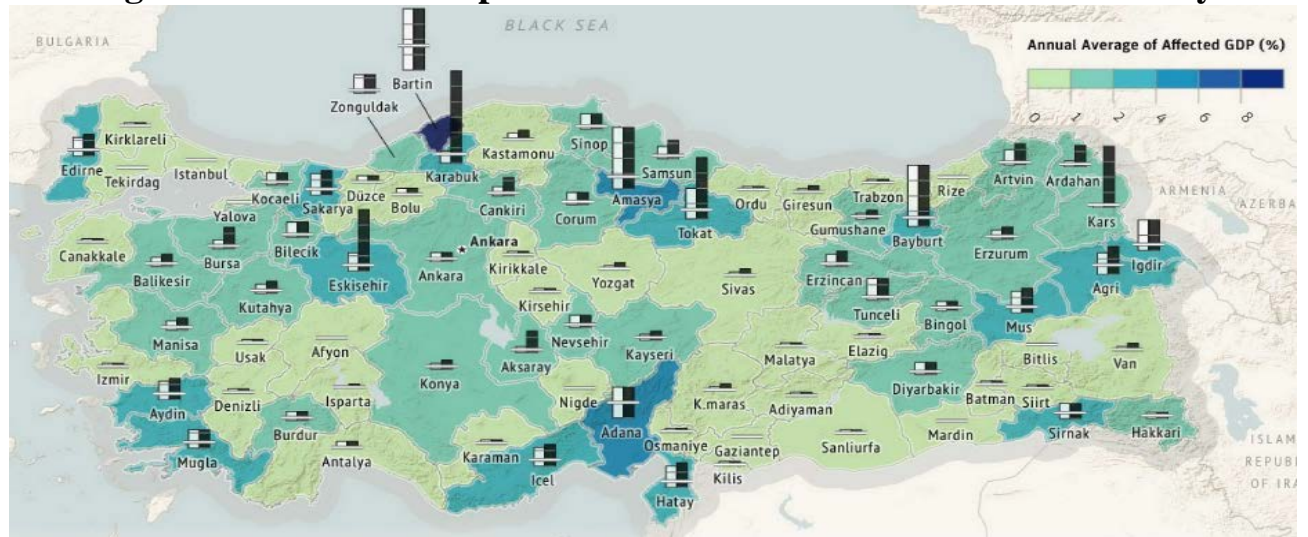

Source: GFDRR, (2016), Europe and Central Asia Country Risk Profiles for Floods and Earthquakes

The Mediterranean region is identified as one of the future climate change "hotspots". Climate models (General Circulation Model, GCM) largely agree on a basin-wide precipitation reduction in the Mediterranean and, in line with this, a number of studies indicate future drying of the Mediterranean and Aegean coastal regions of Turkey and wetting for Black Sea coastal areas. There is a consistent message of precipitation decreases, of the order of 5 $-25 \%$, along the western coasts of Turkey during the first-half of the 21st century. Sensitivity studies have also been conducted to understand the climatic effects on the seas surrounding Turkey. These indicate that warmer summer and autumn sea surface temperatures probably enhance the formation of extreme precipitation events and associated flash floods (Bozkurt et al., 2011) Climatic projections foresee that the temperatures will rise by $2-3^{\circ} \mathrm{C}$ in average and the precipitation will significantly reduce. It is estimated that across Turkey, there will be a significant increase in the number of consecutive dry days, the number of days with frost will decrease and the average temperature in the basins will show an upward trend until 2099 (Sixth National Communication of the Republic of Turkey to the UNFCC, 2014). 
Sectors with highest sensitivity to climate change. Although less documented, floods are frequent events that cause localized losses (Figure 1.3). Climate change induced events faced by the country in the last decade entail more intense precipitation increasing the risks of fluvial and pluvial flooding, and rising sea levels, increasing the risks of flooding in low-lying areas of river deltas and coastal cities. In this context, the most vulnerable sectors are agriculture, electricity, gas, steam and air conditioning supply, forestry, manufacturing as well as restrictive habitats and sensitive ecosystems. The results of the "The Effect of Climate Change on Water Resources Project" Affairs reveal the negative trend in river discharges, causing, among other things, problems related to water availability, water quality and affect the intensity of droughts and floods (Initial Communication of the Republic of Serbia to the UNFCC, 2010). Even though big differences manifest with regard to the number and spatial-temporal pattern of disaster losses in different databases, TABB, Turkey Disaster Database, reported 1076 climate-change induced flood events which caused 795 fatalities and around US \$ 800 million economic loss between 1960 and 2014.

The economic losses accounted for mainly entail physical damage borne by natural disasters, but the greater and undocumented loss comes from loss of income due to performance/productivity losses. This is mostly due to changes in the mean climate patterns (temperature, precipitation and sea level). For example, the harsh winter of 2016 caused severe power outages across the country, the impact on the industrial facilities around the Marmara region is estimated around 1 Billion USD but more work is needed to have reliable figures. Flash flooding due to 10 days of heavy rainfall in 2016 in Mersin resulted in five deaths as well as intense disruption to social and economic activities. The cost of the flood on

Overview of Natural Hazards in Turkey (1960-2014) TABB

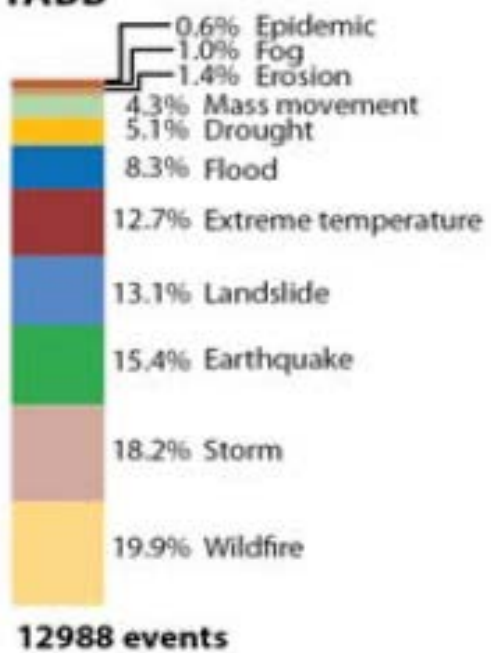
agricultural production was estimated as 116 million TL (in excess of 25 million USD), and on water and sewerage infrastructure was estimated at 5 million TL, whereas the cost of flood to highways and railways was estimated as 3 million TL and 1 million TL respectively. The flood also affected Mersin International Port and connecting roads, causing disruption to port operations and lower throughput (AKFEN Annual Report, 2016). It was reported that the flood disrupted operations at the port for around 12 hours.

\footnotetext{
${ }^{6}$ According to temperature and precipitation projections generated for Turkey by using RCP4.5 scenario MPIESM-MR global data considering reference period including the years between 1971-2000 and period of 20152040.
} 


\section{High-level Critical Infrastructure Risk Assessment (CIRA)}

\subsection{Context of the assessment}

The High-level Critical Infrastructure Risk Assessment in the Region of Çukurova (CIRA) is a study which assesses the risks posed by natural hazards to critical energy and transport and logistics infrastructure in the Çukurova region and provides recommendations for improving resilience in critical infrastructure planning and operation. It aims to develop a pragmatic approach for critical infrastructure risk assessment to make existing infrastructure more resilient as well as to provide guidance for future investments by improving planning processes. Two priority sectors are chosen for the critical infrastructure assessment: (i) energy and (ii) transport/logistics.

The Çukurova region is an important region in Turkey in terms of national economic development and growth since it is a critical hub for both transport/logistics and energy serving as a platform connecting Europe, Middle Asia and the Mediterranean Basin. Furthermore, it is the closest sea gateway for Near East and prosperous inner Anatolia. The Turkish government is aiming to make the region and the cities of Adana and Mersin, an alternative pole for urban development, commerce and tourism, since the Marmara region is already over-populated. The Tenth National Development Plan indicates the intention to have Ceyhan as an Energy hub and ensure the area develops as a significant logistic center to support the integration of Turkey within the EU's Trans-European Transport Network. The region is seen as a potential new metropolitan area and thus, the region plans to invest in several large new infrastructure assets, including a nuclear power plant, an airport, a highway, an energy specialization zone and a logistics center. At the same time, the region is also prone to disasters such as earthquakes and climate change induced disasters. The latest major seismic event in the region was a 6.2 magnitude earthquake in Ceyhan in 1998. Also, the region suffered from landslides, floods and hail storms which damaged industrial facilities and crops. Due to the location and bridging role of Turkey and Çukurova Region, the effects of disasters on critical infrastructure in the region can spread beyond the region as well as national borders. Thus, the Cukurova region was selected as a pilot for conducting an assessment on the resilience of critical infrastructure.

The study was conducted in collaboration with the Çukurova Development Agency (ÇKA), one of the first two regional agencies established in Turkey to foster regional development. It leads the elaboration of 5 and 10-year development plans for the region and has its own investment funding to assist local actors in the implementation of the development plan. The region's growth aspirations and its drive for economic competitiveness would require collective action to strengthen the resilience of its critical infrastructure against disasters and changing climate. By building and promoting resilience at structural as well as institutional levels, the region would have comparative advantages for new investments in its infrastructure which helps meeting multiple regional, and therefore national, socio-economic objectives.

\subsection{Steps and methodology of a critical infrastructure risk assessment}

The CI risk assessment will provide information on:

- The impact on essential services due to the damage and disruption to the infrastructure that lead to reduced assets' performance

- The duration of the disruption, the length in time of unavailability of the CI

- High level estimates of the economic impact i.e. whether it is felt regionally, nationally or transnationally

- "Cascading effects" where disruption to the infrastructure can lead to a chain of events elsewhere 
To do this, a seven-step procedure has been developed which could be replicabled in other regions of Turkey or elsewhere. These steps are presented below:

1. Defining critical infrastructure (CI) for the Çukurova Region

2. Overview of the energy and transport \& logistics sectors in Çukurova

3. Identifying CI in Çukurova's energy and transport \& logistics sectors

4. Natural hazard risk assessment

5. Analyzing current approaches to CI planning \& management

6. Providing recommendations for improving the resilience of $\mathrm{CI}$

7. Identifying sources of funding to build climate resilience into Critical Infrastructure Energy and Transport \& Logistics assets

\subsubsection{Defining critical infrastructure}

There are several definitions of critical infrastructure of governments and international organizations due to drivers of taking action in the case of loss/destruction or disruption of essential functions or services, and consequences of this disruption for health, safety, security, economy, society.

The CIRA works with the definition by Turkey's Disaster and Emergency Management Presidency (AFAD) which provides a comprehensive framework of critical infrastructure as follows: "Combination of networks, assets, systems and structures which can have serious impacts on health, security, and economy of citizens due to adverse impacts on environment, society order and public services that occur as a result of partial or complete loss of functionality of such networks, assets, systems and structures." To provide another example, the Organization for Economic Co-operation and Development (OECD) uses the following definition:" Those interconnected information systems and networks, the disruption or destruction of which would have a serious impact on the health, safety, security, or economic wellbeing of citizens, or on the effective functioning of government or the economy". The UK's approach to the categorization of the nation's critical infrastructure is that 'Infrastructure is categorized according to its value or "criticality" and the impact of its loss". The UK Cabinet Office uses a "Criticality Scale" which assigns categories for different degrees of severity of impact, as explained below.

In general, most of the definitions on the criticality of infrastructure refer to the impact which an infrastructure's loss of function would have on (i) essential services, (ii) the economy (sometimes including environmental effects) and (iii) general life. It is also important to distinguish between different degrees of impact according to the severity, extent (geographical extent or population impacted) and duration. Cascading effects, i.e. interdependencies that can occur between the infrastructure sector and other economic sectors, are usually not stated as a stand-alone criterion, but are considered when evaluating the other criteria. Figure 2.1 is a graphic representation of possible interdependencies between different types of infrastructure (basic infrastructure, socio-economic infrastructure, and socio-cultural infrastructure). 


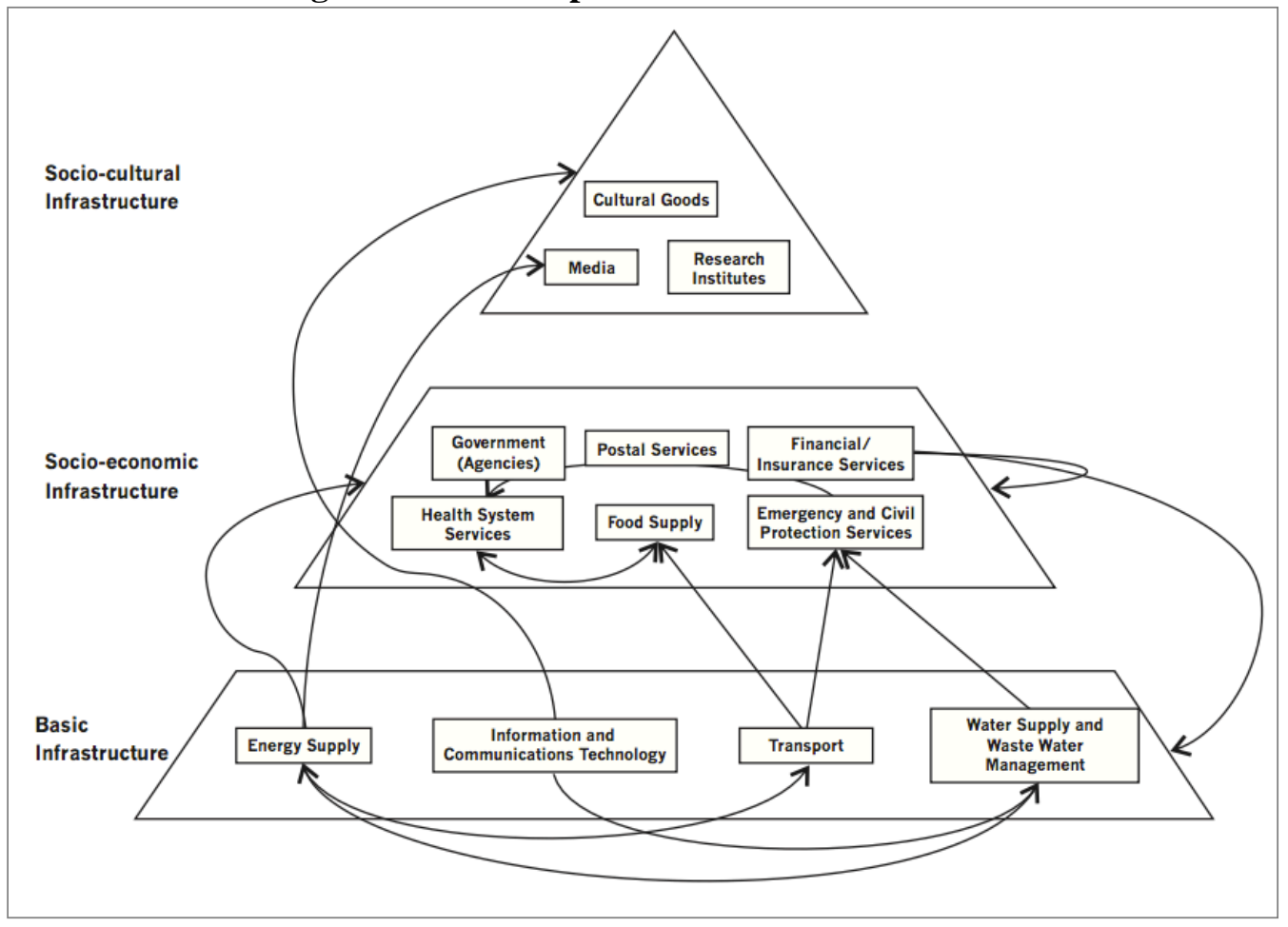

Source: Lauwe and Riegel, 2008

For the categorization of infrastructure, CIRA is referring to a scale which was developed by the UK Cabinet Office, which is publicly available. The categories which are considered as critical infrastructure are Categories 3 - 5 as shown in the table below (Table 2.1). However, this scale does not provide any information on the precise thresholds which are used to rank critical infrastructure.

Table 2.1. UK Cabinet Office's categorization of infrastructure criticality scale

\begin{tabular}{|l|l|}
\hline $\begin{array}{l}\text { Criticality } \\
\text { Scale }\end{array}$ & Description \\
\hline Category $\mathbf{5}$ & $\begin{array}{l}\text { This is infrastructure the loss of which would have a catastrophic impact on the UK. These assets will be of } \\
\text { unique national importance whose loss would have national long-term effects and may impact across a } \\
\text { number of sectors. Relatively few are expected to meet the Category } 5 \text { criteria. }\end{array}$ \\
\hline Category $\mathbf{4}$ & $\begin{array}{l}\text { Infrastructure of the highest importance to the sectors should fall within this category. The impact of the } \\
\text { loss of these assets on essential services would be severe and may impact provision of essential services } \\
\text { across the UK or to millions of citizens }\end{array}$ \\
\hline Category $\mathbf{3}$ & $\begin{array}{l}\text { Infrastructure of substantial importance to the sectors and the delivery of essential services, the loss of which } \\
\text { could affect a large geographic region or many hundreds of thousands of people }\end{array}$ \\
\hline Category $\mathbf{2}$ & $\begin{array}{l}\text { Infrastructure whose loss would have a significant impact on the delivery of essential services leading to } \\
\text { loss, or disruption, of service to tens of thousands of people or affecting whole counties or equivalents }\end{array}$ \\
\hline Category 1 & $\begin{array}{l}\text { Infrastructure whose loss could cause moderate disruption to service delivery, mostly likely on a localized } \\
\text { basis and affecting thousands of citizens }\end{array}$ \\
\hline Category 0 & Infrastructure the impact of the loss of which would be minor (on a national scale) \\
\hline
\end{tabular}

Source: UK Cabinet Office, 2010

\subsubsection{Identifying critical infrastructure in a given sector/region of a country}

In-depth knowledge about the current situation/the existing infrastructure in a given sector/region is necessary to define the critical infrastructure. The CIRA looks specifically at the transport and logistics sectors of the Cukurova region.

The CIRA uses the criteria described above for the identification of critical infrastructure. Since there is no information publicly available regarding the precise thresholds which are used to rank critical 
infrastructure, the CIRA uses major disasters that happened in Turkey in recent years to derive impact thresholds (see Table 2.2 below).

Table 2.2. Natural hazards experienced in Turkey used to define impact thresholds

\begin{tabular}{|l|l|l|l|}
\hline & Impacts on essential services & Economic impact & Impacts on life \\
\hline Event & National blackout (31 March 2015) & Marmara earthquake (1999) & Mersin floods (29 Dec 2016) \\
\hline Impact & $\begin{array}{l}\text { Loss of power across Turkey for several } \\
\text { hours, (within 6.5 hours, power had } \\
\text { been restored to 80\% of the grid; some } \\
\text { provinces were without power for 9 } \\
\text { hours). (Economic losses due to lost } \\
\text { load are estimated to be in excess of } \\
\text { USD 1 billion) }\end{array}$ & $\begin{array}{l}\text { Five lives lost. Economic } \\
\text { losses to agricultural } \\
\text { production and infrastructure } \\
\text { damage, estimated at more } \\
\text { than USD 35 million7. }\end{array}$ \\
\hline
\end{tabular}

Source: Prepared in the CIRA study.

The hazards from Table 2.2 were used to develop the categorization of critical infrastructure in the CIRA report. Disasters which are resulting in impacts on life, i.e. the Mersin floods (2016) are always assigned the highest category (Category 5) according to the criticality scale by the UK Cabinet Office. The national blackout (2015) as well as the Marmara earthquake (1999) were used as benchmarks for 'impacts on essential services' (national blackout) as well as 'economic impact' (Marmara earthquake). They were classified as Category 4 impacts because their impacts were national (not transnational). The CIRA looks at regional, national and transnational impacts and only hazards with a 'geographical extent' of a 'transnational impact' are assigned to the highest Category (Category 5).

Table 2.3 shows the result of the critical infrastructure categorization for the Cukurova region. Only Categories 3-5 were developed in the table as only these are considered as 'critical', following the categorization of the UK Cabinet Office (as presented in Table 2.1).

Table 2.3. Categorization of critical infrastructure in the CIRA

\begin{tabular}{|c|c|c|c|}
\hline \multirow{2}{*}{$\begin{array}{l}\text { Criticality } \\
\text { Scale }\end{array}$} & \multicolumn{3}{|l|}{ Description } \\
\hline & Impacts on essential services & $\begin{array}{l}\text { Economic impact } \\
\text { (impact on Turkey’s } \\
\text { GDP, \%) }\end{array}$ & Impacts on life \\
\hline Category 5 & $\begin{array}{l}\text { Geographical extent: Transnational } \\
\text { This is infrastructure, the loss of which would } \\
\text { have a catastrophic impact. The loss of these } \\
\text { assets would have transnational long-term effects } \\
\text { on delivery of essential services. }\end{array}$ & $>10$ & $\begin{array}{l}\text { The loss of these assets may } \\
\text { impact quality of life for } \\
\text { millions of Turkish citizens } \\
\text { and citizens in other countries } \\
\text { or may lead to single or } \\
\text { multiple fatalities. }\end{array}$ \\
\hline Category 4 & $\begin{array}{l}\text { Geographical extent: National } \\
\text { Infrastructure of the highest importance should } \\
\text { fall within this category. The impact of the loss } \\
\text { of these assets on essential services would be } \\
\text { severe and may impact provision of essential } \\
\text { services nationwide. }\end{array}$ & $>5 \%$ to 10 & $\begin{array}{l}\text { The loss of these assets may } \\
\text { impact quality of life for } \\
\text { millions of Turkish citizens or } \\
\text { may lead to major or multiple } \\
\text { injuries, permanent injury or } \\
\text { disability. }\end{array}$ \\
\hline Category 3 & $\begin{array}{l}\text { Geographical extent: Regional } \\
\text { Infrastructure of substantial importance to the } \\
\text { delivery of essential services, the loss of which } \\
\text { could affect a whole region. }\end{array}$ & $>1 \%$ to 5 & $\begin{array}{l}\text { The impact of the loss of these } \\
\text { assets may impact quality of } \\
\text { life for hundreds of thousands } \\
\text { of citizens or may lead to } \\
\text { serious injury. }\end{array}$ \\
\hline
\end{tabular}

Source: Prepared in the CIRA study.

\footnotetext{
${ }^{7}$ Using currency exchange rates TRY / USD as of December 2016
} 
The table above, which was developed by the CIRA, provides a robust categorization of critical infrastructure in Cukurova. One approach would be to classify each of the region's transport/logistics and energy infrastructure assets according to the categorization. However, this would require significant research time and effort, which was not possible to be conducted under the CIRA. Thus, if there are limited resources available, a more practical approach is suggested, which has also been applied for the CIRA. For the categorization, it can be looked at as the economic impact as well as the geographical extent, which are two of the main comparators as identified above. More specifically, the two factors are: (i) an estimation of the economic impact according to the loss/disruption of service provided by the critical infrastructure due to the experienced hazardous event, expressed as a percentage of the country's GDP and, (ii) the geographical extent of the impact of the hazardous event on essential services.

The approach taken in the CIRA comprises three steps. To start with, an expert estimation regarding the economic impact associated with the loss of service provided by critical infrastructure (expressed a percentage of Turkey's GDP), is carried out. In the case of the CIRA, this was done for the two chosen sectors: the energy as well as the transport/logistics sector. In this report, the energy sector will be used as an example to showcase the methodology which has been used for this assessment in the CIRA. As shown in Table 2.4, experts have estimated the dependency of Turkey's GDP on electricity and natural gas.

Table 2.4: Dependency of Turkey's GDP on electricity and natural gas

\begin{tabular}{|l|c|c|c|c|c|}
\hline & $\mathbf{2 0 1 5}$ & $\mathbf{2 0 1 4}$ & $\mathbf{2 0 1 3}$ & $\mathbf{2 0 1 2}$ & $\mathbf{2 0 1 1}$ \\
\hline GDP (USD billions, 2015 prices) & 719.6 & 799.4 & 823.0 & 786.3 & 774.0 \\
\hline Annual Electricity Consumption (GWh) & 216,233 & 207,375 & 198,045 & 194,923 & 186,100 \\
\hline Annual Natural Gas Consumption $\left(\mathrm{Mm}^{3}\right)$ & 47,999 & 48,717 & 45,918 & 45,242 & 43,697 \\
\hline GDP/GWh (USD/GWh) & 3.3 & 3.9 & 4.2 & 4.0 & 4.2 \\
\hline GDP/m ${ }^{3}\left(\mathrm{USD} / \mathrm{m}^{3}\right)$ & 15 & 16 & 18 & 17 & 18 \\
\hline
\end{tabular}

Source: Prepared in the CIRA study.

In a second step, the main electricity-generating and natural gas infrastructure assets of a given area are analyzed according to their capacity. Using the values of the above table the loss in GDP is calculated, acting on the assumption of an interruption of the service delivery for 3 months and no substitution for the asset. Table 2.5 shows the estimations from the CIRA for the impact on Turkey's GDP from loss of service of selected energy infrastructure assets in Cukurova region.

Table 2.5: Impact on Turkey's GDP from loss of service of selected energy infrastructure assets in Cukurova region

\begin{tabular}{|l|c|c|c|}
\hline Energy Asset & $\begin{array}{c}\text { Capacity (GWh } \\
\text { [power plants] or } \\
\text { billion } \mathbf{~ m}^{3} \text { [natural } \\
\text { gas storage] }\end{array}$ & $\begin{array}{c}\text { \% GDP loss if } \\
\text { service cannot be } \\
\text { replaced for 3 } \\
\text { months* }\end{array}$ & $\begin{array}{c}\text { GDP loss (million } \\
\text { USD) per day of lost } \\
\text { service (downtime) }\end{array}$ \\
\hline Sanibey Yedigöze Hydropower Plant & 672 & 0.078 & 6.1 \\
\hline Iskenderun Sugozu Thermal Power Plant & 9,183 & 1.1 & 84 \\
\hline Akkuyu Nuclear PP** & 35,000 & 4.1 & 315 \\
\hline Tarsus Underground Natural Gas Storage** & 5.2 & 2.7 & 210 \\
\hline
\end{tabular}

Source: Prepared in the CIRA study.

*Based on 2016 GDP.

**Not yet operational.

In a third step, the geographical extent of the interruption of the service of an infrastructure asset is also analyzed, i.e. it is assessed whether the interruption would be felt on a regional scale, a national scale or whether it would have transboundary effects. The CIRA assessment classified infrastructure assets which have transboundary impacts as Category 5 (Akkuyu Nuclear Power Plant and Baku-Tbilisi oil 
pipeline) and those ones which are limited to national boundaries as Category 4 (Yumurtalik-Kırıkkale oil pipeline) assets. Category 4 and Category 5 infrastructure assets are classified as critical infrastructure. Based on the analysis of the geographical extent as well as the impact on the GDP, three assets have been identified as critical infrastructure in the energy sector in the Cukurova region in the CIRA report.

The same type of assessment was also carried out for the transport and logistics sector in the CIRA report. In transportation and logistics sectors, geographical extent of the transport and logistics assets' disruption is considered as level of criticality of the asset. Assets such as Mersin International Port and Çukurova International Airport emerge as Category 5, due to their transnational significance for imports and exports, as do major access roads or railways serving Middle Eastern countries. Seyhan Viaduct is classified as a Category 3 due to the regional impacts of its disruption.

Existing infrastructure in the Çukurova Region, together with new infrastructure under development, can be classified as 'critical'. For new infrastructure under development, less information is available as a basis for analysis in the CIRA. Therefore, only existing infrastructure was taken forward for further analysis. The critical infrastructures that were analyzed in the risk assessment, together with their capacity and the estimated GDP loss per day of downtime, are summarized in Table 2.6: Sanibey Yedigoze Hydropower Plant was assessed even though it is not large enough to be considered critical today, because there are plans to develop many more hydropower plants in the region.

Based on the assessment, the CIRA identified five existing critical infrastructure assets in the energy and transport/logistics sector in the Cukurova region, with estimated losses in a natural hazard risk assessment.

Table 2.6: Selected critical infrastructure in Çukurova Region

\begin{tabular}{|c|c|c|}
\hline Infrastructure & Capacity & $\begin{array}{l}\text { Estimated GDP loss per day } \\
\text { of downtime (million USD) } \\
\text { (a) }\end{array}$ \\
\hline Sanibey Yedigoze Hydropower Plant & $672 \mathrm{GWh}$ & 6.1 \\
\hline İsken Sugözü Thermal Power Plant & 9,183 GWh & 84 \\
\hline Yumurtalik-Kırıkkale Oil Pipeline & 141,000 barrels per day & $11.6^{(\mathrm{b})}$ \\
\hline Mersin International Port & 1.8 million TEUs/year & 21 \\
\hline Seyhan Viaduct on E-90 & 36,232 vehicles/day & 5.1 \\
\hline $\begin{array}{l}\text { (a) GDP estimated as a } \\
\text { http://data.worldbank.org/country } \\
\text { (b) The figure for the oil pipeline incl } \\
\text { disruption of oil supplies via the } \\
\text { Loss of tax revenue to the govern } \\
\text { not represent a full picture of GDI } \\
\text { pipeline disruption. }\end{array}$ & $\begin{array}{l}\text { of } 2015 \text { total } \\
\text { loss of revenue for the re } \\
\text { sssuming that disruption l } \\
\text { to loss of sales of refinec } \\
\text { her it provides a partial }\end{array}$ & $\begin{array}{l}\text { P for Turkey. Source: } \\
\text { owners associated with } \\
\text { o lost refinery production (2) } \\
\text { ucts. This figure therefore does } \\
\text { f the economic impact of }\end{array}$ \\
\hline
\end{tabular}

\subsubsection{Natural hazard risk assessment}

\subsubsection{Methodology}

The CIRA uses a risk assessment methodology according to seven steps developed by the Intergovernmental Panel on Climate Change (IPCC) (see Figure 2.2 below). The following seven steps are performed according to the IPCC methodology:

1. Identification of critical infrastructure assets

2. Development of hazard scenarios (geo-physical and climate) 
3. Initial screening of assets for susceptibility to hazards (i.e. potential occurrence of a natural or human-induced physical event)

4. Collection of vulnerability data

5. Collection of exposure data

6. Risk model implemented in RiskAPP

7. Assessment of the risks

Figure 2.2: Risk assessment methodology according to seven steps from the CIRA

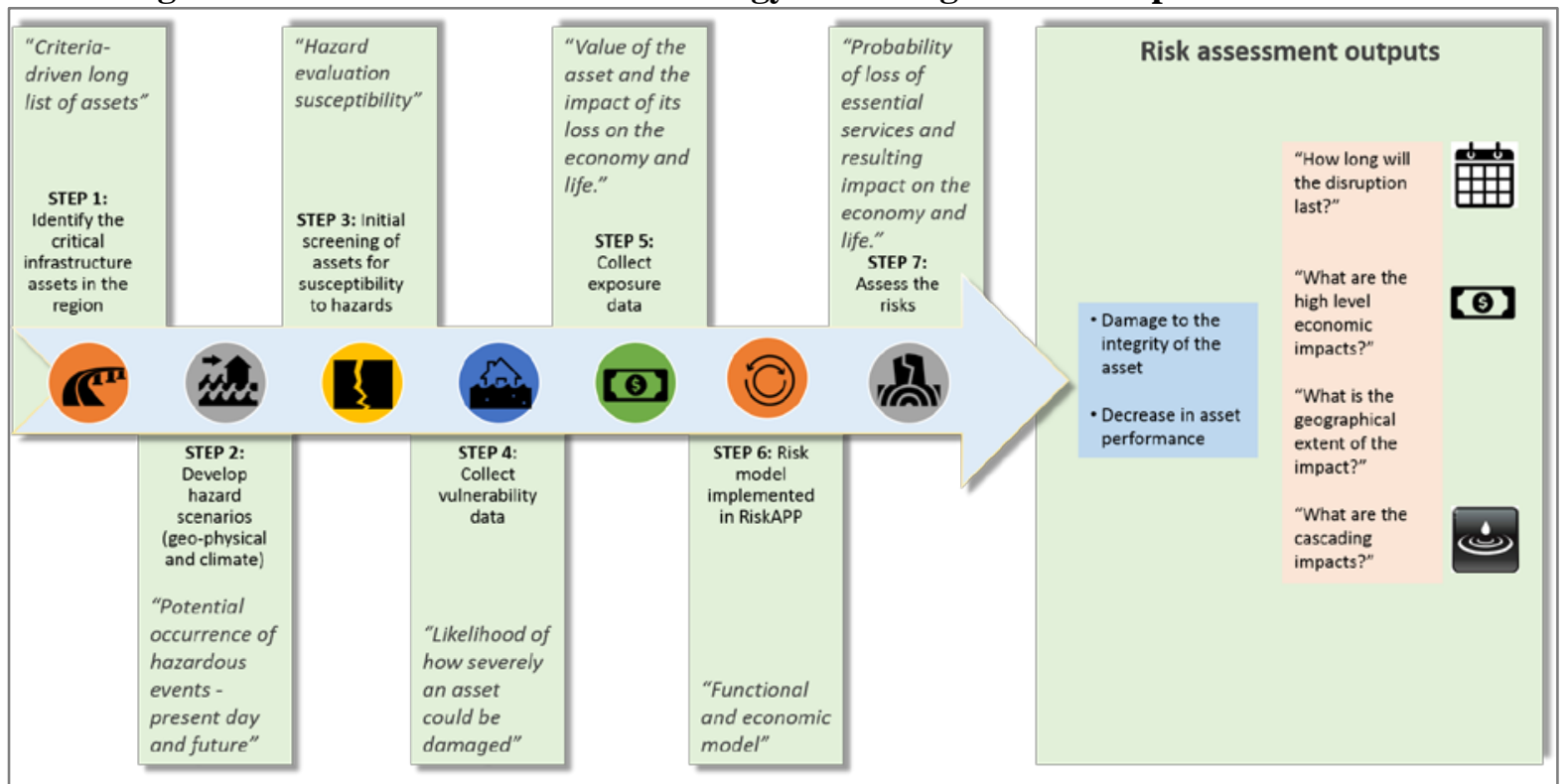

Source: Prepared in the CIRA study.

Current and future hazard scenarios in Cukurova Region are presented in Table 2.7 below. The results in this table are based on expert assumptions; an upward arrow indicates an a likely increase in the expected hazard level in the future (a double arrow indicates a strong increase) whereas a downward arrow shows a decrease and a dash indicates that no change in the hazard level is expected.

Table 2.7: Current and future levels of hazards in Cukurova region

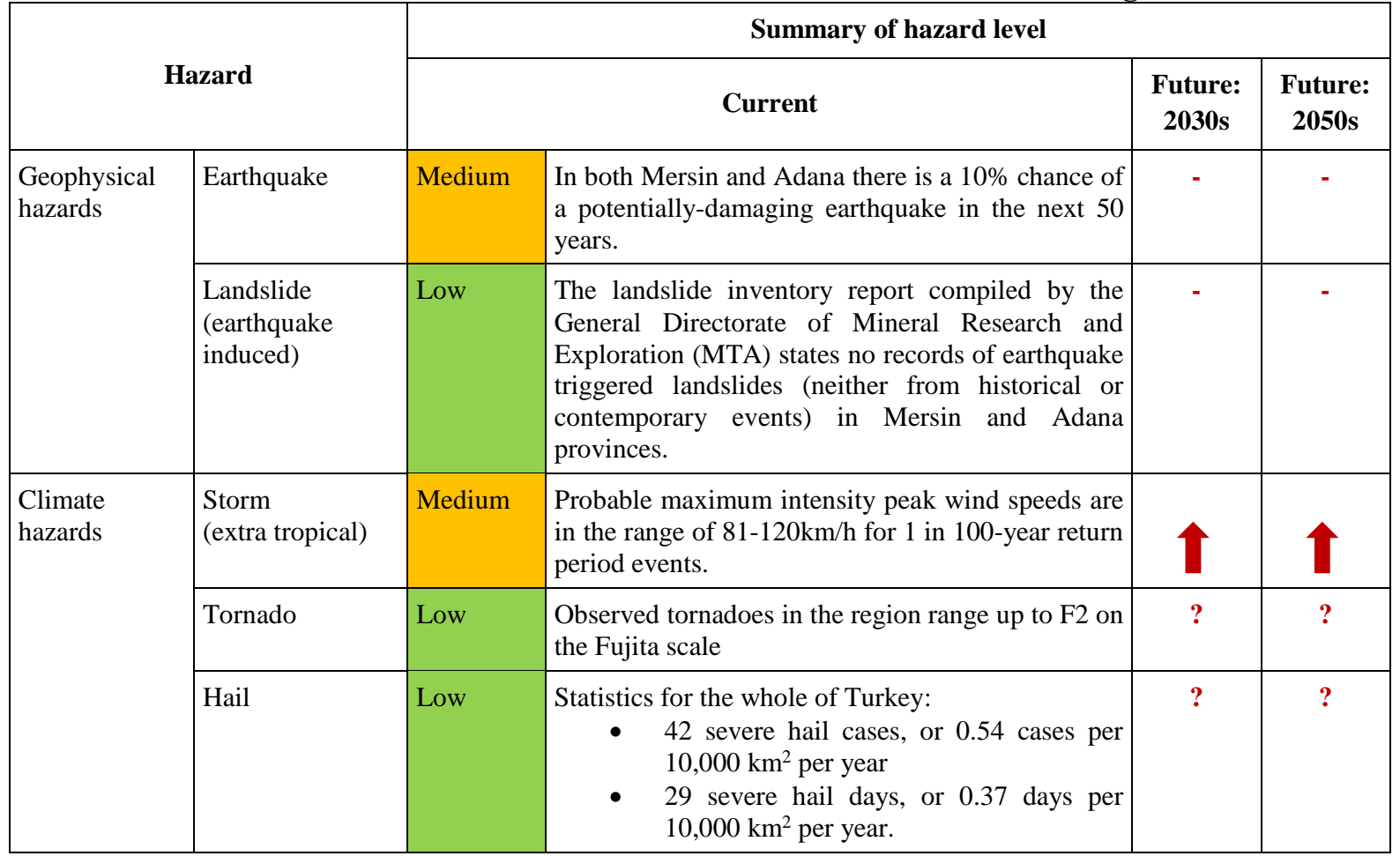




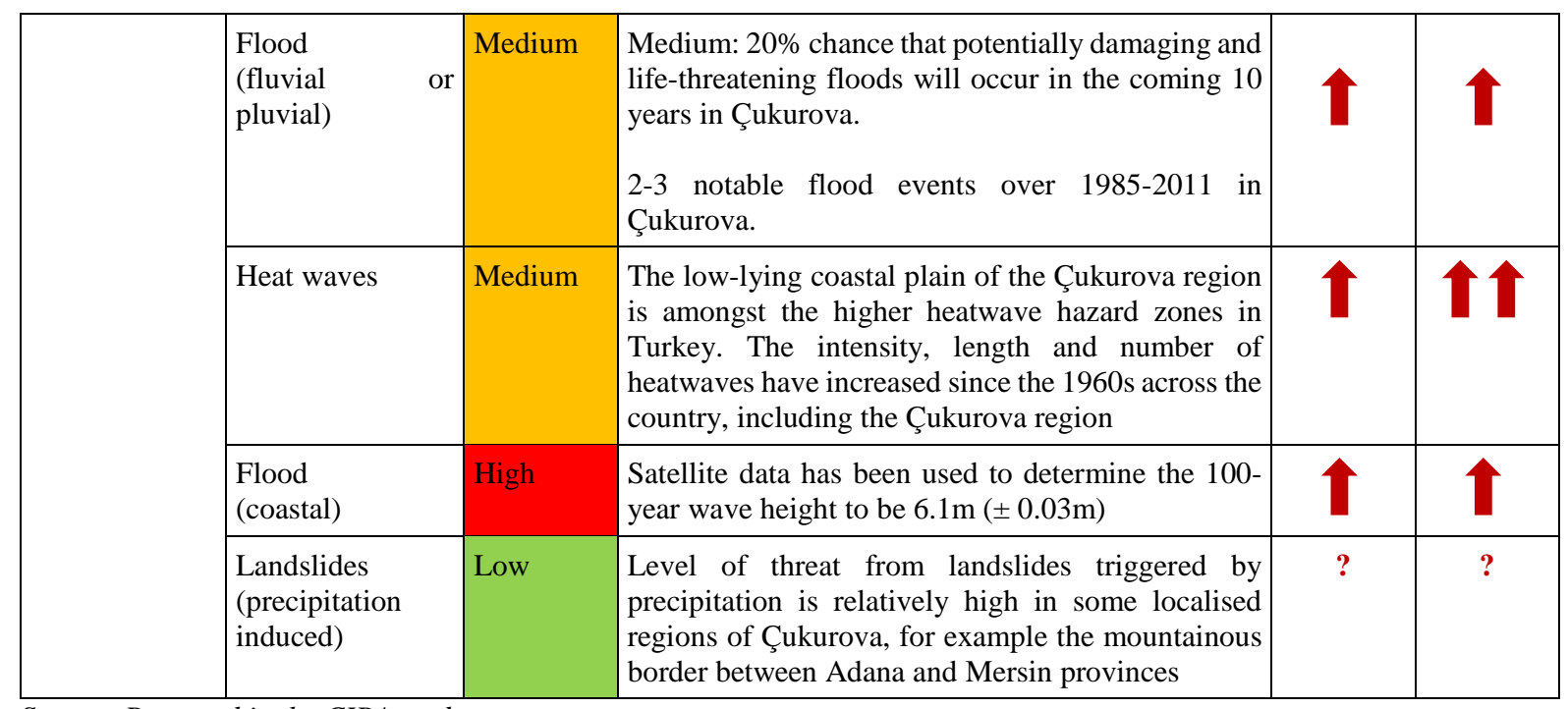

Source: Prepared in the CIRA study.

In Step 3 experts move on to screening the identified critical infrastructure assets for their susceptibility to hazards. In Steps 4 and 5 data on vulnerability, i.e. the likelihood of the severity of damage to an infrastructure asset, as well as exposure, i.e. the value of an infrastructure asset as well the impact of damaging this asset, are collected. Box 1.1 below shows more extensive definitions by the IPCC of hazard, vulnerability, exposure and risk, which are applied in this risk assessment.

\section{Box 1.1: Definitions by the IPCC applied in this risk assessment \\ Hazard is defined by the IPCC as "the potential occurrence of a natural or human-induced physical event or trend or physical impact that may cause loss of life, injury, or other health impacts, as well as damage and loss to property, infrastructure, livelihoods, service provision, ecosystems and environmental resources." In this risk assessment, the level of hazard is given by the current and future frequency and magnitude of adverse climate and geophysical events. \\ Vulnerability is defined by the IPCC as the "The propensity or predisposition to be adversely affected. Vulnerability encompasses a variety of concepts and elements including sensitivity or susceptibility to harm and lack of capacity to cope and adapt." In this risk assessment, vulnerability is given by the relationship between hazard events and the damage (or decrease in efficiency) this will cause expressed in percentage or category of damage to the CI.}

Exposure is defined by the IPCC as "The presence of people, livelihoods, species or ecosystems, environmental functions, services, and resources, infrastructure, or economic, social, or cultural assets in places and settings that could be adversely affected." In this risk assessment, exposure is given by the economic impact and geographical extent of the cascading consequences if the $\mathrm{CI}$ is damaged.

Risk is defined by the IPCC as the probability of occurrence of hazardous events or trends (associated with its magnitude) multiplied by the impacts (e.g. on the economy) if these events or trends occur. Risk results from the interaction of vulnerability, exposure, and hazard.

Source: Prepared in the CIRA study.

In Step 6 of the risk assessment all the collected information is inserted into the platform RiskAPP to conduct the risk assessment. RiskAPP is used to quantify the impact of scenarios of hazards on downtime, loss of service and the economic consequences.

In Step 7 of the risk assessment the outputs of the RiskAPP platform are then further analyzed. In this analysis the potential level of damage to the critical infrastructure, the length of the disruption (days of 
downtime), high-level economic impacts, the geographical extent of the impact and cascading impacts are considered. To calculate the economic risk per year, the economic impact of downtime is multiplied by the amount of days of downtime expected and this number is then further multiplied by the exceedance probability of the hazard per year to arrive at the economic risk per year (see Box 1.2).

\section{Box 1.2: Calculation of the economic risk per year}

Downtime [days] $\mathrm{x}$ Daily economic impact of downtime $=$ economic impact (GDP loss) [million USD] (Equation 1)

Economic risk per year [million USD] = economic impact (GDP loss) [million USD] x Exceedance probability per year (\%) (Equation 2)

Source: Prepared in the CIRA study.

The estimated GDP loss per day of downtime of critical infrastructures that were analyzed in the risk assessment together with their capacity are presented below (Table 2.8).

Table 2.8 Estimated GDP losses of selected critical infrastructures in Çukurova Region

\begin{tabular}{|c|c|c|}
\hline Energy Asset & $\begin{array}{c}\text { Capacity (GWh [power plant] } \\
\text { and barrels per day } \\
\text { [pipeline]) }\end{array}$ & $\begin{array}{l}\text { Estimated GDP loss per day of } \\
\text { downtime (million USD)* }\end{array}$ \\
\hline Sanibey Yedigoze Hydropower Plant & 672 & 6.1 \\
\hline İsken Sugözü Thermal Power Plant & 9,183 & 84 \\
\hline Yumurtalik-Kırıkkale Oil Pipeline & 141,000 & $11.6 * *$ \\
\hline \multicolumn{3}{|c|}{$\begin{array}{l}\text { ** The figure for the oil pipeline includes: (1) loss of revenue for the refinery owners associated with } \\
\text { disruption of oil supplies via the pipeline, assuming that disruption leads to lost refinery production (2) Loss } \\
\text { of tax revenue to the government due to loss of sales of refined products. This figure therefore does not } \\
\text { represent a full picture of GDP loss; rather it provides a partial view of the economic impact of pipeline } \\
\text { disruption }\end{array}$} \\
\hline Transport \& Logistics Asset & Capacity & $\begin{array}{l}\text { Estimated GDP loss per day of } \\
\text { downtime (million USD)* }\end{array}$ \\
\hline Mersin International Port & 1.8 million TEUs/year & 21 \\
\hline Seyhan Viaduct on E-90 & 36,232 vehicles/day & 5.1 \\
\hline
\end{tabular}

The findings of a natural hazard risk assessment are now shown on the basis of an example of the transport sector, the Mersin International Port, which is part of the five assets of critical infrastructure which have been identified in the CIRA. Table 2.9 shows a summary of the damage, downtime, impact and economic risk of each hazard scenario at Mersin International Port. 
Table 2.9: Summary of the risk assessment findings for Mersin International Port

\begin{tabular}{|c|c|c|c|c|c|c|c|c|c|c|}
\hline $\begin{array}{c}\text { Scenario } \\
\text { no. }\end{array}$ & Hazard & $\begin{array}{l}\text { Intensity } \\
\text { measure } \\
\text { value }\end{array}$ & Unit & $\begin{array}{l}\text { Exceedance } \\
\text { Probability } \\
\text { per year }^{8}\end{array}$ & $\begin{array}{l}\text { Time } \\
\text { period }\end{array}$ & $\begin{array}{l}\text { Physical } \\
\text { phenomena }\end{array}$ & Damage \% & $\begin{array}{l}\begin{array}{l}\text { Downti } \\
\text { me }\end{array} \\
\text { [days] }\end{array}$ & $\begin{array}{l}\text { Economic } \\
\text { impact (GDP } \\
\text { loss) [million } \\
\text { USD] }^{9}\end{array}$ & $\begin{array}{l}\text { Economic } \\
\text { risk per year } \\
\text { [million } \\
\text { USD] }^{10}\end{array}$ \\
\hline \# 1 & Storm & $81-120$ & $\mathrm{~km} / \mathrm{h}$ & $1.00 \%$ & current & Wind speed & 10 & 1 & 21 & 0.21 \\
\hline$\# 2$ & Storm & $121-160$ & $\mathrm{~km} / \mathrm{h}$ & $1.00 \%$ & 2030s & Wind speed & 15 & 15 & 315 & 3.15 \\
\hline \# 3 & Tornado & $\begin{array}{l}117-180 \\
\text { (F1) }\end{array}$ & $\mathrm{km} / \mathrm{h}$ & $0.33 \%$ & current & Wind speed & 10 & 1 & 21 & 0.07 \\
\hline \# 4 & Tornado & $\begin{array}{l}181-253 \\
\text { (F2) }\end{array}$ & $\mathrm{km} / \mathrm{h}$ & $0.17 \%$ & current & Wind speed & 50 & 30 & 630 & 1.07 \\
\hline \# 5 & $\begin{array}{l}\text { Coastal } \\
\text { Flood }\end{array}$ & 6.1 & $\mathrm{~m}$ & $1.00 \%$ & current & $\begin{array}{l}\text { Max wave } \\
\text { height }\end{array}$ & 50 & 60 & 1260 & 12.60 \\
\hline \# 6 & $\begin{array}{l}\text { Coastal } \\
\text { Flood }\end{array}$ & 6.2 & $\mathrm{~m}$ & $1.00 \%$ & $2030 s$ & $\begin{array}{l}\text { Max wave } \\
\text { height }\end{array}$ & 50 & 60 & 1260 & 12.60 \\
\hline \# 7 & $\begin{array}{l}\text { Coastal } \\
\text { Flood }\end{array}$ & 6.3 & $\mathrm{~m}$ & $1.00 \%$ & $2050 \mathrm{~s}$ & $\begin{array}{l}\text { Max wave } \\
\text { height }\end{array}$ & 50 & 60 & 1260 & 12.60 \\
\hline \# 8 & $\begin{array}{l}\text { Coastal } \\
\text { Flood }\end{array}$ & 10.0 & $\mathrm{~m}$ & $1.00 \%$ & 2050s & $\begin{array}{l}\text { Max wave } \\
\text { height }\end{array}$ & 50 & 60 & 1260 & 12.60 \\
\hline \# 9 & $\begin{array}{l}\text { Flood } \\
\text { (Flash) }\end{array}$ & - & $\mathrm{cm}$ & - & current & Water depth & - & 15 & - & * \\
\hline \# 10 & $\begin{array}{l}\text { Heat } \\
\text { wave }\end{array}$ & 32 & ${ }^{\circ} \mathrm{C}$ & $20.00 \%$ & current & $\begin{array}{l}\text { Air } \\
\text { temperature }\end{array}$ & 0 & 0 & 0 & 0 \\
\hline \# 11 & $\begin{array}{l}\text { Heat } \\
\text { wave }\end{array}$ & 41 & ${ }^{\circ} \mathrm{C}$ & $20.00 \%$ & $2030 s$ & $\begin{array}{l}\text { Air } \\
\text { temperature }\end{array}$ & 0 & 0 & 0 & 0 \\
\hline \# 12 & $\begin{array}{l}\text { Heat } \\
\text { wave }\end{array}$ & 54 & ${ }^{\circ} \mathrm{C}$ & $20.00 \%$ & 2050s & $\begin{array}{l}\text { Air } \\
\text { temperature }\end{array}$ & 10 & 2 & 42 & 8.40 \\
\hline$\# 13$ & $\begin{array}{l}\text { Earthqu } \\
\text { ake }\end{array}$ & $\begin{array}{l}0.060 \text { (D- } \\
\text { soil) }\end{array}$ & g & $2.33 \%$ & current & $\begin{array}{l}\text { Peak ground } \\
\text { acceleration }\end{array}$ & 5 & 0 & 0 & 0 \\
\hline$\# 14$ & $\begin{array}{l}\text { Earthqu } \\
\text { ake }\end{array}$ & $\begin{array}{l}0.085 \text { (D- } \\
\text { soil) }\end{array}$ & g & $1.39 \%$ & current & $\begin{array}{l}\text { Peak ground } \\
\text { acceleration }\end{array}$ & 5 & 0 & 0 & 0 \\
\hline \# 15 & $\begin{array}{l}\text { Earthqu } \\
\text { ake }\end{array}$ & $\begin{array}{l}0.218 \text { (D- } \\
\text { soil) }\end{array}$ & g & $0.21 \%$ & current & $\begin{array}{l}\text { Peak ground } \\
\text { acceleration }\end{array}$ & 5 & 0 & 0 & 0 \\
\hline$\# 16$ & $\begin{array}{l}\text { Earthqu } \\
\text { ake }\end{array}$ & $\begin{array}{l}0.350 \text { (D- } \\
\text { soil) }\end{array}$ & g & $0.04 \%$ & current & $\begin{array}{l}\text { Peak ground } \\
\text { acceleration }\end{array}$ & 10 & 5 & 105 & 0.04 \\
\hline
\end{tabular}

Source: Prepared in the CIRA study.

Mersin International Port is exposed to a variety of hazards comprising coastal floods, storms tornados, heat waves and earthquakes. Coastal floods are the most damaging hazards (see scenarios 5-8) which might lead to a damage of $50 \%$ of the port, with a $1.00 \%$ likelihood (which means a return period of 100 years). The coastal floods scenarios also show the longest duration of downtime, i.e. 60 days as well as the highest estimated economic risk (12.6 million USD per year). The most likely hazard is a heat wave (scenarios 10-12) with an estimated annual frequency of $20 \%$. A disruption of services at

\footnotetext{
${ }^{8}$ Assuming one year analysis period.

${ }^{9}$ Economic impacts for future time periods are undiscounted

${ }^{10}$ Economic risks for future time periods are undiscounted
} 
Mersin International port would have transboundary effects to harbors in other countries as well as cascading impacts to other ports and carriers, to producers and customers of goods imported and exported via the port as well as transportation authorities.

The visualization of the risks for Mersin international port which is prepared via using RiskAPP is presented below (Figure 2.3). The y-axis represents the cumulative GDP damage over the lifetime of the asset (in million USD) and the size of the circle shows the annual average expected economic risk in million USD. Figure 2.3 shows the same result as Table 2.9, i.e. that the Mersin International port is at highest risk from coastal floods and heatwaves.

Figure 2.3: Economic risk at Mersin International Port

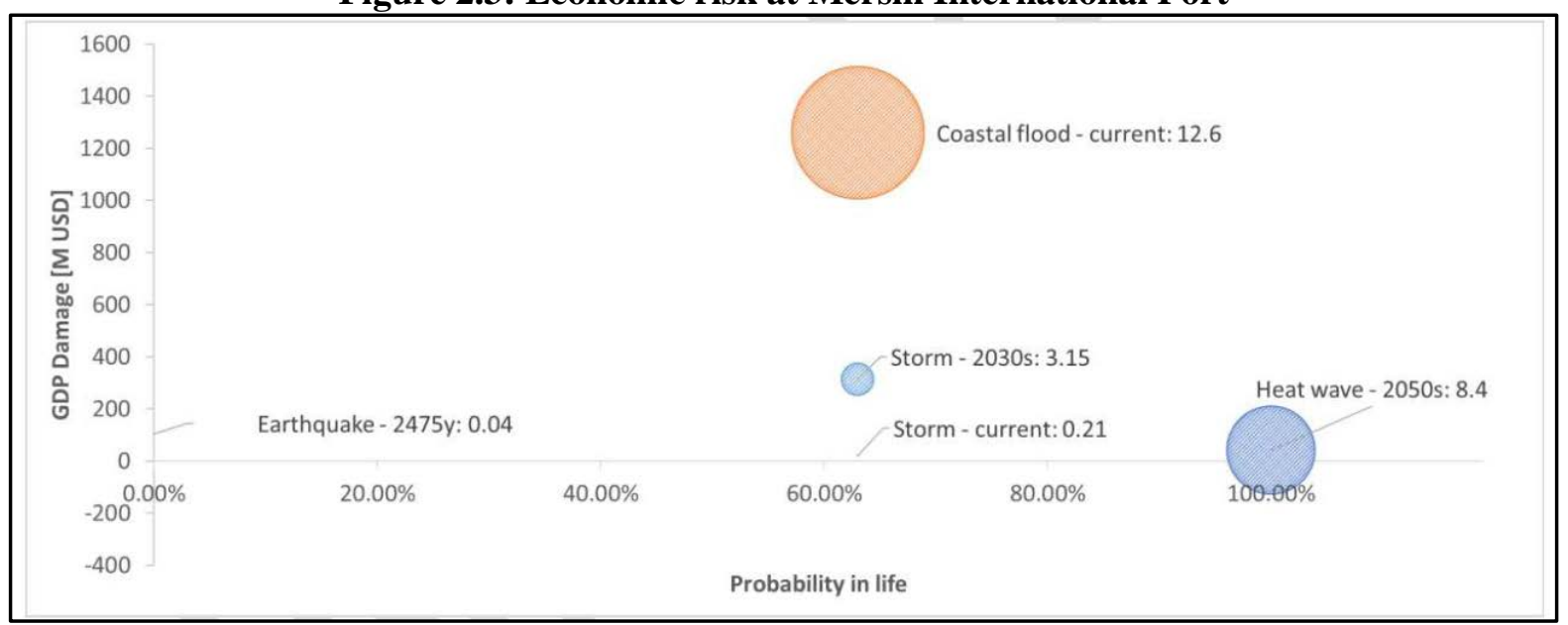

Source: Prepared in the CIRA study.

\subsubsection{Analyses of current approaches to CI planning \& management in policy documents}

The scope of the CIRA also aims at integration of natural hazard risk assessments and resilience elements in the national and regional planning process. To do so, the report reviews in the Turkish context how decisions on the development of critical infrastructures are made, ways to make decision makers responsible for critical infrastructure and to influence decision-makers on improved risk management / resilience for climate and geological hazards.

On development planning in Turkey, 5-10 years Development Plans are the highest-level planning tools which determine the framework of macro-economic, social and environmental development objectives of the country. Also, another function of the development plan is to provide guidance for public and private investments in Turkey. Development plans provide direction to sectoral policies/strategies. In turn, policies provide guidance to plans and programs at different levels.

\subsubsection{Providing recommendations for improving the resilience of CI}

There are several methodological frameworks which categorize respective risk management options to improve the resilience of the $\mathrm{CI}$ as structural and non-structural:

- Structural options include engineered solutions such as redesigning buildings and designing physical barriers to reduce damage from disaster events;

- Non-structural options include social solutions such as early warning systems, contingency planning, emergency response preparedness and risk transfer through insurance.

Table 2.10 below summarizes the measures which can be undertaken in any country where the choice of appropriate options, the decision on timing and the level of investment is highly contingent on the national context and the range of projected natural hazards/climate change risks and their consequences. 
Table 2.10: Matrix of risk assessment and management measures

\begin{tabular}{|c|c|c|c|c|c|c|c|c|}
\hline \multirow[b]{2}{*}{ Type of measure } & \multirow[b]{2}{*}{ Description } & \multirow[b]{2}{*}{ UNISDR definition $^{11}$} & \multirow[b]{2}{*}{ Ex-ante } & \multirow[b]{2}{*}{ Ex-post } & \multirow{2}{*}{$\begin{array}{c}\text { Structural } \\
\text { Physical } \\
\text { resilience }\end{array}$} & \multicolumn{3}{|c|}{ Non-structural } \\
\hline & & & & & & $\begin{array}{l}\text { Physical } \\
\text { resilience }\end{array}$ & $\begin{array}{l}\text { Socio- } \\
\text { economic } \\
\text { resilience }\end{array}$ & $\begin{array}{l}\text { Human } \\
\text { resilience }\end{array}$ \\
\hline Risk assessment & $\begin{array}{l}\text { Qualitative or } \\
\text { quantitative } \\
\text { approach to } \\
\text { determine the nature } \\
\text { and extent of risk. }\end{array}$ & $\begin{array}{l}\text { A methodology to determine the nature and } \\
\text { extent of risk by analyzing potential hazards } \\
\text { and evaluating existing conditions of } \\
\text { vulnerability that together could potentially } \\
\text { harm exposed people, property, services, } \\
\text { livelihoods and the environment on which } \\
\text { they depend. }\end{array}$ & $\mathrm{X}$ & & & & & \\
\hline Risk prevention & $\begin{array}{l}\text { Reducing losses } \\
\text { through anticipating } \\
\text { events and through } \\
\text { resilient design, } \\
\text { operation and } \\
\text { maintenance }\end{array}$ & $\begin{array}{l}\text { The outright avoidance of adverse impacts of } \\
\text { hazards and related disasters }\end{array}$ & $\mathrm{X}$ & & $\mathrm{X}$ & $\mathrm{X}$ & & \\
\hline Risk reduction & $\begin{array}{l}\text { Reducing damage } \\
\text { caused by natural } \\
\text { hazards through an } \\
\text { ethic of prevention. }\end{array}$ & $\begin{array}{l}\text { The concept and practice of reducing disaster } \\
\text { risks through systematic efforts to analyses } \\
\text { and manage the causal factors of disasters, } \\
\text { including through reduced exposure to } \\
\text { hazards, lessened vulnerability of people and } \\
\text { property, wise management of land and the } \\
\text { environment, and improved preparedness for } \\
\text { adverse events }\end{array}$ & $\mathrm{X}$ & & $\mathrm{X}$ & $\mathrm{X}$ & $\mathrm{X}$ & $\mathrm{X}$ \\
\hline $\begin{array}{l}\text { Financial } \\
\text { protection }\end{array}$ & $\begin{array}{l}\text { Sharing and } \\
\text { transferring risk and } \\
\text { improving access to } \\
\text { finance following an } \\
\text { event }\end{array}$ & $\begin{array}{l}\text { The process of formally or informally } \\
\text { shifting the financial consequences of } \\
\text { particular risks from one party to another } \\
\text { thereby a household, community, enterprise } \\
\text { or state authority will obtain resources from } \\
\text { the other party after a disaster occurs, in } \\
\text { exchange for ongoing or compensatory social } \\
\text { or financial benefits provided to that other } \\
\text { party }\end{array}$ & $\mathrm{X}$ & $\mathrm{X}$ & & & $\mathrm{X}$ & \\
\hline Preparedness & $\begin{array}{l}\text { Raising awareness, } \\
\text { hazardous event } \\
\text { response exercises } \\
\text { etc. }\end{array}$ & $\begin{array}{l}\text { The knowledge and capacities developed by } \\
\text { governments, professional response and } \\
\text { recovery organizations, communities and } \\
\text { individuals to effectively anticipate, respond } \\
\text { to, and recover from, the impacts of likely, }\end{array}$ & $\mathrm{X}$ & & & & & $\mathrm{X}$ \\
\hline
\end{tabular}

${ }^{11}$ ISDR. 2009. UNISDR Terminology on Disaster Risk Reduction. UN International Strategy for Disaster Reduction. 


\begin{tabular}{|c|c|c|c|c|c|c|c|c|}
\hline & & & & & Structural & \multicolumn{3}{|c|}{ Non-structural } \\
\hline Type of measure & Description & UNISDR definition $^{11}$ & Ex-ante & Ex-post & $\begin{array}{l}\text { Physical } \\
\text { resilience }\end{array}$ & $\begin{array}{l}\text { Physical } \\
\text { resilience }\end{array}$ & $\begin{array}{l}\text { Socio- } \\
\text { economic } \\
\text { resilience }\end{array}$ & $\begin{array}{l}\text { Human } \\
\text { resilience }\end{array}$ \\
\hline & & $\begin{array}{l}\text { imminent or current hazard events or } \\
\text { conditions }\end{array}$ & & & & & & \\
\hline $\begin{array}{l}\text { Resilient } \\
\text { reconstruction }\end{array}$ & $\begin{array}{l}\text { Re-instating } \\
\text { damaged } \\
\text { infrastructure better } \\
\text { designed to cope } \\
\text { with hazardous } \\
\text { events }\end{array}$ & $\begin{array}{l}\text { [Re-instating a damaged] system, community } \\
\text { or society exposed to hazards to resist, } \\
\text { absorb, accommodate to and recover from } \\
\text { the effects of a hazard in a timely and } \\
\text { efficient manner, including through the } \\
\text { reservation and restoration of its essential } \\
\text { basic structures and functions }\end{array}$ & & $\mathrm{X}$ & $\mathrm{X}$ & & & \\
\hline $\begin{array}{l}\text { Socio economic } \\
\text { recovery }\end{array}$ & $\begin{array}{l}\text { Re-instating the } \\
\text { socio-economic } \\
\text { environment, with } \\
\text { greater resilience } \\
\text { where practicable } \\
\end{array}$ & $\begin{array}{l}\text { The restoration, and improvement where } \\
\text { appropriate, of facilities, livelihoods and } \\
\text { living conditions of disaster-affected } \\
\text { communities, including efforts to reduce } \\
\text { disaster risk factors. }\end{array}$ & & $\mathrm{X}$ & & & $\mathrm{X}$ & \\
\hline Response & $\begin{array}{l}\text { Reacting to, and } \\
\text { recovering from, } \\
\text { hazardous events }\end{array}$ & $\begin{array}{l}\text { The provision of emergency services and } \\
\text { public assistance during or immediately after } \\
\text { a disaster to save lives, reduce health } \\
\text { impacts, ensure public safety and meet the } \\
\text { basic subsistence needs of the people } \\
\text { affected }\end{array}$ & & $\mathrm{X}$ & & & & $\mathrm{X}$ \\
\hline
\end{tabular}


Structural and non-structural risk management options for critical infrastructure which can be applied in various sectors are presented below.

Table 2.11: Non-structural risk management measures

\begin{tabular}{|c|c|}
\hline $\begin{array}{l}\text { Type of option and } \\
\text { hazard type }\end{array}$ & Key actions \\
\hline \multicolumn{2}{|l|}{ Risk prevention } \\
\hline $\begin{array}{l}\text { ing policies } \\
\text { evelopment } \\
\text { l }\end{array}$ & $\begin{array}{l}\text { - Facilitate dialogue on effective coordination of resilience with national and regional authorities. } \\
\text { Encourage stakeholders to take ownership of Regional Development Plans. } \\
\text { - Examine regional demographic trends to predict future demand for infrastructure and competition } \\
\text { for shared resources (e.g. water). } \\
\text { - Embed climate resilience and critical infrastructure themes into regional development plans and } \\
\text { strategies. } \\
\text { - Make use of the physical (spatial) planning hierarchy as an effective tool for better integration of } \\
\text { risks posed by natural hazards at various levels of planning. } \\
\text { - Use sub-regional Environmental Plans as entry points within which to incorporate information on } \\
\text { natural hazards and their future changes }\end{array}$ \\
\hline & $\begin{array}{l}\text { - Implement data collection, research and projects on regional climate change and impacts on critical } \\
\text { infrastructure. } \\
\text { - Establish open-data portals on natural disasters observed in the region, including best available } \\
\text { scientific findings on future regional climate change. } \\
\text { - Support studies on quantifying direct and indirect economic costs and wider benefits (social and } \\
\text { environmental) of building resilience in infrastructure. } \\
\text { - Organize workshops on conducting vulnerability and risk assessments for regional stakeholders. } \\
\text { Develop a complete picture of how interruptions and failures could affect their business, services, } \\
\text { or lives. } \\
\text { - Identify key dependencies / interdependencies of critical infrastructure in the region and map how } \\
\text { critical infrastructure assets, system, or networks could impact other components of socio- } \\
\text { economic systems; map potential cascading effects from infrastructure disruptions regionally, } \\
\text { nationally and transnationally. } \\
\text { - Use finer-scale plans such as Urban Master Plans, Urban Implementation Plans and Rural } \\
\text { Development Plans to map natural hazards and to zone areas at high risk. } \\
\text { - Incorporate consideration of a non-stationary climatic baseline and future changes in } \\
\text { environmental impact assessments (EIAs). }\end{array}$ \\
\hline & $\begin{array}{l}\text { - Include key actors at different levels of government, private sector and civil society when } \\
\text { developing risks management systems. } \\
\text { - Link Disaster Risk Management (DRM) with natural hazard risk management incorporating } \\
\text { climate change. } \\
\text { - Integrate natural hazard risk management within existing processes and standards which cover } \\
\text { supply chain security, business continuity, quality management, environmental management, } \\
\text { health \& safety, auditing and due diligence. }\end{array}$ \\
\hline & $\begin{array}{l}\text { - Adhere to earthquake design and construction codes and standards. } \\
\text { - Use climate model outputs and local disaster profiles to stress test infrastructure design and } \\
\text { adaptation options, including different configurations of infrastructure and operation } \\
\text { rules/management practices. }\end{array}$ \\
\hline \multicolumn{2}{|l|}{ Financial protection } \\
\hline & $\begin{array}{l}\text { - Review insurance policies for Force Majeure/Act of God definitions, exclusions and adequacy of } \\
\text { cover. Assess cover for asset damage, business interruption, public liability, and business } \\
\text { interruption and ingress/egress. Analyze past claims triggered by natural hazards and costs to the } \\
\text { facility in excesses, lack of cover or outright exclusions. } \\
\text { - Monitor insurance industry research on including climate change risks in policies. Determine how } \\
\text { these could affect future cover, premiums and exclusions. }\end{array}$ \\
\hline
\end{tabular}




\begin{tabular}{|c|c|}
\hline $\begin{array}{l}\text { Weather index } \\
\text { based insurance } \\
\text { - }\end{array}$ & $\begin{array}{l}\text { - Investigate coverage based upon climate parameters correlated with certain losses. This approach } \\
\text { protects from situations where there is a well-defined climate risk that could cause operational } \\
\text { reduction / losses. }\end{array}$ \\
\hline PPP contracts & $\begin{array}{l}\text { - Incorporate a changing risk landscape in PPP / BOT legislation and contracts. Force Majeure risk } \\
\text { and associated financial loss allocation should be revaluated in the context of a changing climatic } \\
\text { baseline and return periods for extreme events. } \\
\text { - Ensure investment partners, project designers and operators understand potential changes in the } \\
\text { frequency and magnitude of extreme weather-related events. }\end{array}$ \\
\hline \multicolumn{2}{|l|}{ Preparedness } \\
\hline $\begin{array}{l}\text { Contingency / } \\
\text { business continuity } \\
\text { management }\end{array}$ & $\begin{array}{l}\text { - Develop plans in cooperation with local stakeholders to identify risks associated with: } \\
\text { o major disasters immediately preventing normal operation, } \\
\text { o gradually worsening situations (e.g. prolonged high temperatures) that make normal operation } \\
\text { difficult, } \\
\text { o multi-hazard smaller events occurring simultaneously or in sequence. } \\
\text { - Plans should include risks to physical assets, equipment failures, transport disruption, supplier } \\
\text { impacts, staff availability. } \\
\text { - Plans should outline: } \\
\text { o actions to be taken immediately after an event, } \\
\text { o actions to allow the service to continue, actions to allow full recovery of operations. }\end{array}$ \\
\hline $\begin{array}{l}\text { Emergency } \\
\text { management plan }\end{array}$ & $\begin{array}{l}\text { - Develop plans to reduce vulnerabilities to extreme events, include elements such as purchasing } \\
\text { adequate insurance coverage to cover assets or financial losses, where to evacuate staff in the event } \\
\text { of a disaster (preparedness), and seeking financial assistance post-disaster (recovery). }\end{array}$ \\
\hline $\begin{array}{l}\text { Desktop incident } \\
\text { management } \\
\text { exercises }\end{array}$ & $\begin{array}{l}\text { - Apply a multi-agency co-operation approach. } \\
\text { - Emergency exercises involving multiple agencies and simulated incidents can help individuals and } \\
\text { organizations collectively prepare for situations using a real-time approach. }\end{array}$ \\
\hline $\begin{array}{l}\text { Forecast / early } \\
\text { warning / rapid } \\
\text { response systems }\end{array}$ & $\begin{array}{l}\text { - Work closely with meteorological, hydrological and disaster agencies to monitor immediate/short } \\
\text { term/seasonal/long-term threats. This allows operational decisions to be made based on forecasts } \\
\text { or immediate threats. This is particularly valuable in forecasting extreme events, supporting } \\
\text { decision-making such as evacuating facilities and operational shut down. } \\
\text { - Implement rapid response systems which allow for automatic control and shut-down of critical } \\
\text { infrastructure systems. }\end{array}$ \\
\hline \multicolumn{2}{|c|}{ (a) References: Expert team. } \\
\hline \multicolumn{2}{|c|}{ CIRIA (2010). Flood resilience and resistance for critical infrastructure. CIRIA C688 } \\
\hline \multicolumn{2}{|c|}{$\begin{array}{l}\text { SeDIF (2013). Earthquake Damage and Fragilities of the Industrial Facilities. Mustafa Erdik, Eren Uckan. International } \\
\text { Conference on Seismic Design of Industrial Facilities, Aachen University, 26-27 September } 2013 .\end{array}$} \\
\hline \multicolumn{2}{|c|}{$\begin{array}{l}\text { World Bank (2016) Emerging Trends in Mainstreaming Climate Resilience in Large Scale, Multi-sector Infrastructure } \\
\text { PPPs. A GLOBAL KNOWLEDGE PRODUCT. }\end{array}$} \\
\hline
\end{tabular}

Source: Prepared in the CIRA study. 


\section{Structural risk management options}

Risk management options for Port structures are given as example below.

Table 2.12: Structural risk management measures for Port

\begin{tabular}{|c|c|}
\hline $\begin{array}{l}\text { Type of option and } \\
\text { hazard type }\end{array}$ & Key actions \\
\hline \multicolumn{2}{|l|}{ Risk prevention } \\
\hline Flood protectior & $\begin{array}{l}\text { - Upgrade drainage systems inside ports to increase maximum capacity and manage increased } \\
\text { flow. } \\
\text { - Retrofit buildings and storage areas vulnerable to flooding, in particular critical components } \\
\text { (e.g. insulate electrical equipment, use water resistant materials). } \\
\text { - Review options for using sustainable drainage systems (SUDS). }\end{array}$ \\
\hline & - Raise quay heights to prevent flooding and account for future sea level rise and storm surges. \\
\hline Dredging and disposal & $\begin{array}{l}\text { - Support maintenance of sediment and water quality within harbors provided by natural } \\
\text { ecosystems. }\end{array}$ \\
\hline Sedimentation & - Upgrade and improve sediment traps. \\
\hline Road integrity & - Replace road surfaces with materials resistant to prolonged elevated temperature. \\
\hline Refrigeration and & $\begin{array}{l}\text { - Increase efficiency of cooling / freezing equipment. } \\
\text { - Isolate electrical connections to reduce exposure to water and dust, reducing incidents of loss } \\
\text { of power to reefers and extra energy for re-cooling/re-freezing. }\end{array}$ \\
\hline & - Retrofit handling areas with covers to protect from heavy rainfall events. \\
\hline Earthquake protection & $\begin{array}{l}\text { - Control effects of ground shaking on storage tanks and cranes etc. using accelerometric } \\
\text { networks, active and passive control systems. }\end{array}$ \\
\hline \multicolumn{2}{|l|}{ Resilient reconstruction } \\
\hline Flood pro & $\begin{array}{l}\text { - Construct sustainable drainage systems (SUDS) inside ports with a climate change allowance } \\
\text { to manage increased flow. } \\
\text { - Fit new buildings and storage areas with insulated electrical equipment and water resistant } \\
\text { materials. }\end{array}$ \\
\hline & $\begin{array}{l}\text { - Construct quay heights to prevent flooding and account for future sea level rise and storm } \\
\text { surges. }\end{array}$ \\
\hline Dredging and disposal & $\begin{array}{l}\text { - Support introduction of, or increase in, natural ecosystems to help manage sediment and } \\
\text { maintain water quality within harbors. }\end{array}$ \\
\hline Sedimentation & $\begin{array}{l}\text { - Use sediment traps designed to manage future changes in rainfall and sediment / pollutant } \\
\text { mobilization from surfaces. }\end{array}$ \\
\hline Road integr & - Construct road surfaces with materials resistant to prolonged elevated temperature. \\
\hline Refrigeration and & $\begin{array}{l}\text { - Implement best available technology for efficient cooling / freezing equipment. } \\
\text { - Construct using isolated electrical connections to reduce exposure to water and dust. }\end{array}$ \\
\hline Storage areas & - Construct handling areas with covers to protect from future increases in heavy rainfall events. \\
\hline Earthquake protection & $\begin{array}{l}\text { - Construct with monitoring and control of effects of ground shaking on storage tanks and cranes } \\
\text { using accelerometric networks, active and passive control systems. }\end{array}$ \\
\hline Thermal comfort of & $\begin{array}{l}\text { - Apply energy-efficient solutions to reduce thermal discomfort and potential heat stress to } \\
\text { workers (e.g. natural ventilation, mechanical air cooling and conventional cooling systems). }\end{array}$ \\
\hline
\end{tabular}


Type of option and

Key actions

hazard type

Sources:

SeDIF (2013). Earthquake Damage and Fragilities of the Industrial Facilities. Mustafa Erdik, Eren Uckan. International

Conference on Seismic Design of Industrial Facilities, Aachen University, 26-27 Sep 2013.

IDB (2015). Port of Manzanillo: Climate Risk Management. Action Plan.

Source: Prepared in the CIRA study. 


\section{Key Agricultural Product Risk Assessment (KAPRA)}

\subsection{Context of the assessment}

The Key Agricultural Product Risk Assessment (KAPRA) study aims to develop financial options to build resilience in Izmir's agricultural economy and competitiveness by taking into account the effects of climate change and the risks associated with it as well as the sustainability of natural resources and social dynamics. It is one of the first in Turkey to look at the effects of climate change on agricultural outputs and to suggest solutions for economically viable climate change adaptation and resilience measures in the agricultural sector.

Izmir region plays an important role in the agricultural production in Turkey and is especially well-known for organic agriculture and alternative agro-food systems and is one of the centers for livestock in the Aegean region and in Turkey. Its agricultural economy has grown 2.5 times more than the national average in the last decade with financial incentives and regional planning and is now host to major processing and storage facilities, as well as being one of Turkey's agricultural export-import centers. The share of the provincial agricultural sector in the agricultural Gross Value Added (GVA) of the Aegean Region is 22.3\%, accounting for $4 \%$ of Turkey's agricultural GVA. Furthermore, Izmir region is located in one of the active fault lines which produces damaging earthquakes and the region will likely be one of the hot spots affected by climate change. The geographical scope of study is particularly the Kucuk Menderes River Basin (KMRB) which is part of the Izmir region covering approximately 700,000 hectares and has favorable meteorological, geological and hydrological conditions for agricultural production. Eight district counties in the KMRB were studied, which are the Bayındır, Beydağ, Kiraz, Menderes, Odemis, Selçuk, Tire and Torbalı districts.

The study was conducted in collaboration with the Izmir Development Agency (IZKA) which is one of the first two agencies established to foster regional development in Turkey. It aims to become a forerunner in sustainable local development by introducing new technologies and concepts and by providing financing to implement them. Therefore, IZKA contributed to this study to better understand the scope and depth of climate impact on agricultural products, and to develop a series of resilience solutions considering economic, ecological and social dimensions.

\subsection{Steps and methodology of a key agricultural products risk assessment}

To conduct a key agricultural products risk assessment, the following steps are followed:

1. Developing a framework for categorizing "key agricultural products"

2. Selection of key agricultural products in a given region/country

3. Assessing climate change risks through the production chain for the selected key agricultural products

4. Identifying resilience solutions

\subsubsection{Framework for categorizing Key Agricultural Products}

In the KAPRA assessment, key agricultural products have been defined as follows: "Products on which other producers and users in the region depend and that have a significant share in regional and national 
supply, and whose absence may create a snowball effect that extends beyond the boundaries of the sector and the province. Forming resistance to climate change involves taking customizable actions (i) to mitigate risks that may have an impact on the physical integrity of an agricultural/natural asset and/or disturb its core function and (ii) to ensure optimum productivity and quality by taking into account potential changes in current conditions (average temperature, precipitation regime, etc.).”

In the study, a variety of sources were consulted for the selection of key agricultural products: policy and strategy papers for adaptation to climate change at a national as well as a regional scale, statistical data related to parameters for defining key products, international best practices for the selection of key agricultural products, as well as interviews and workshops with various local stakeholders. The whole process of selecting key products was supported by expert inputs. Figure 3.1 visualizes the process of the selection of key agricultural products in the KAPRA.

\section{Figure 3.1 Process of key agricultural products selection in the KAPRA study}

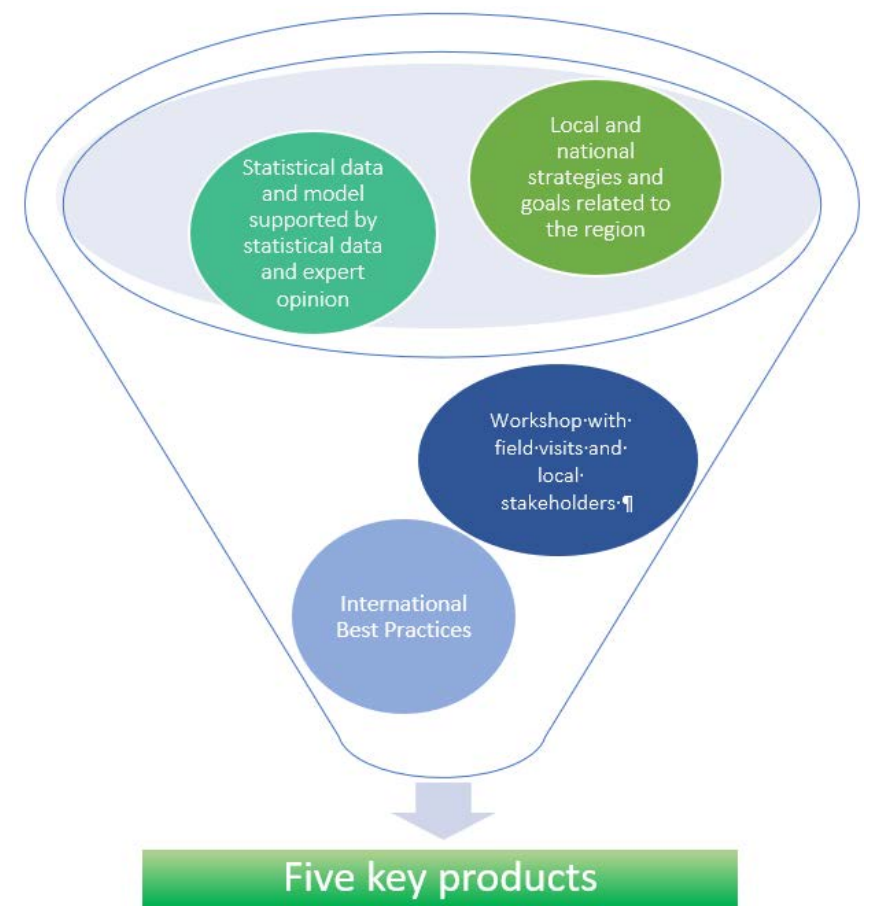

Source: Prepared in the KAPRA study.

The local and national strategies as well as the statistical data are very distinctive to the particular region/country where the key agricultural products risk assessment is conducted. The lessons from the analysis of international best practices are also relevant for other regions/countries beyond the KAPRA. The KAPRA highlights the following points for the study of international best practices:

- Focus on studies dealing with both agriculture as well as industrial sectors linked to agriculture

- Focus on studies with similarities between the climatic conditions studied in the international reports and the region/country of the assessment

- Focus on studies with similarities between the types of land studied in the international reports and the region/country of the assessment 
- Focus on studies with similarities between social dynamics in the international reports and the region/country of the assessment

- Look at reports with matching goals of the study

There are also some take-aways from the stakeholder discussions which are relevant for other regions/countries beyond the scope of the KAPRA. A wide variety of public and private stakeholders as well as civil society organization which are working on agricultural and rural development in the Kucuk Menderes River Basin have been consulted in the KAPRA. The following important points have been raised regarding the selection criteria for key agricultural products:

- High economic value of the product and high value added when the product is processed

- Decreasing dependency on imports

- Level of know-how of the farmers in the region

- Having a comparative advantage in the production of the product compared to other regions

- Complementarity to production of other products

- Capacity to adapt to climate change

Out of all the inputs by experts, stakeholders, statistical data and policy papers and studies a scoring matrix for selecting the key agricultural products in the Kucuk Menderes River Basin has been developed for the KAPRA report. The indicators of the scoring matrix are comprised of the economic, social and environmental impacts of the production of the product. Figure 3.2 gives more details on each of these three areas.

Figure 3.2: Indicators for key agricultural product selection in the KAPRA study
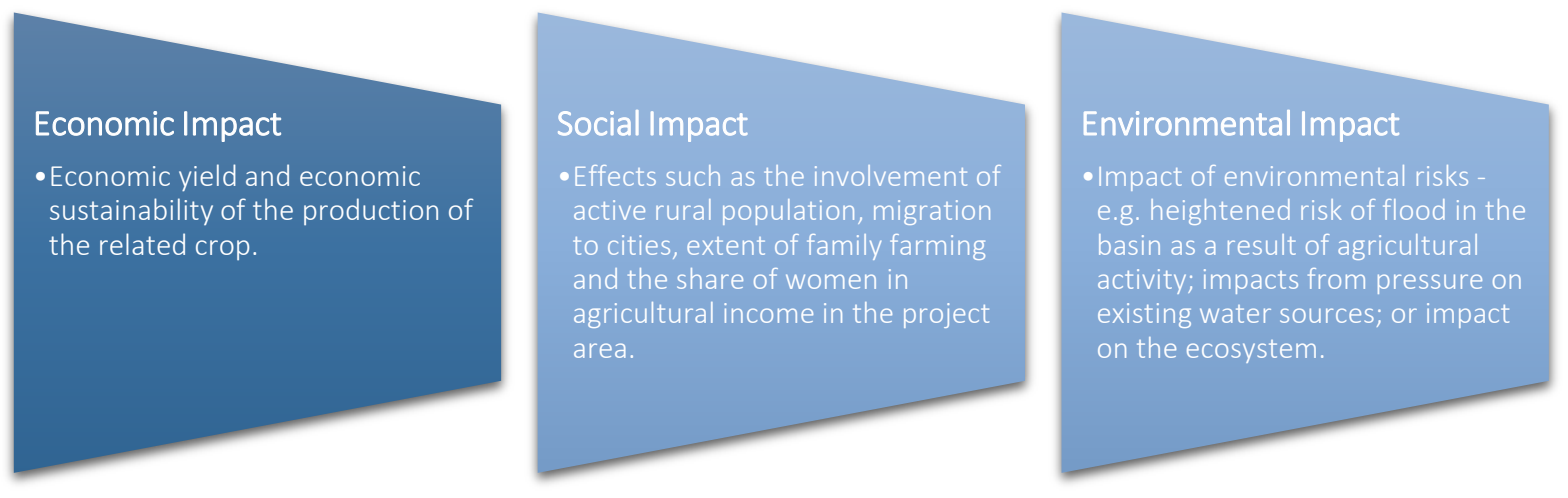

Source: Prepared in the KAPRA study.

The weight of these indicators has been set in line with the goals of the project as well as the priorities of project stakeholders. The indicators also take into consideration the strategic priorities of the country and the region based on the strategy papers analyzed and have been determined by a group of experts comprising different disciplines (agronomists, agricultural financing experts, and rural and social development specialists). Table 3.1 shows the indicators and their weights for the KAPRA assessment. In order to arrive at the final score, the economic, social and environmental criteria are weighted, at 34\%, 33\% and 33\% respectively. In a final step, the weights are multiplied by the scores for the economic, social and environmental criteria for each product which gives the total score. As a result, a score is provided for each 
product and the products with the highest scores are perceived as a region's/country's key agricultural products.

Table 3.1: Indicators and their weights in the KAPRA report

\begin{tabular}{|c|c|c|c|c|c|}
\hline Economic Criteria & $\begin{array}{l}\text { Weight } \\
(\%)\end{array}$ & Social Criteria & $\begin{array}{l}\text { Weight } \\
(\%)\end{array}$ & Environmental Criteria & $\begin{array}{l}\text { Weight } \\
(\%)\end{array}$ \\
\hline If the product is exported & 9 & $\begin{array}{c}\text { Potential to create jobs for } \\
\text { women in the production of the } \\
\text { product }\end{array}$ & 12 & $\begin{array}{l}\text { Daily water consumption of the } \\
\text { product in a production cycle } \\
\text { depending on climatic and soil } \\
\text { conditions in Izmir }\end{array}$ & 11.2 \\
\hline $\begin{array}{l}\text { Ratio of the production value } \\
\text { of the product in the KMRB to } \\
\text { its production value in Turkey }\end{array}$ & 8 & Intensive family farming & 12 & $\begin{array}{l}\text { Product's blue water footprint } \\
\text { in Izmir province }\end{array}$ & 9.4 \\
\hline $\begin{array}{l}\text { Ratio of the product's growing } \\
\text { area in the KMRB to total } \\
\text { agricultural lands in the KMRB }\end{array}$ & 8 & $\begin{array}{l}\text { Ratio of registered farmers } \\
\text { producing the product in the } \\
\text { KMRB to the total number of } \\
\text { registered farmers in the } \\
\text { KMRB }\end{array}$ & 10 & $\begin{array}{l}\text { Impact of the production of the } \\
\text { product on groundwater quality }\end{array}$ & 9.3 \\
\hline $\begin{array}{l}\text { Agricultural industry for which } \\
\text { the product is an input }\end{array}$ & 8 & $\begin{array}{l}\text { Existence and activeness of } \\
\text { farmers' organizations } \\
\text { producing the product }\end{array}$ & 10 & $\begin{array}{l}\text { Intensity of groundwater use } \\
\text { for production of the product }\end{array}$ & 8.5 \\
\hline $\begin{array}{l}\text { Ratio of the product's } \\
\text { production in the KMRB to its } \\
\text { production in Izmir }\end{array}$ & 7 & $\begin{array}{l}\text { Total labor intensity in the } \\
\text { KMRB regarding the product }\end{array}$ & 10 & $\begin{array}{l}\text { Product's grey water footprint } \\
\text { in Izmir province }\end{array}$ & 8.1 \\
\hline $\begin{array}{l}\text { Ratio of annual production cost } \\
\text { of the product to annual gross } \\
\text { income (per hectare/animal) }\end{array}$ & 7 & $\begin{array}{l}\text { Production of product creates } \\
\text { continuous/stable employment }\end{array}$ & 9 & $\begin{array}{l}\text { Energy requirement for the } \\
\text { production process related to } \\
\text { the product in the KMRB }\end{array}$ & 7.7 \\
\hline $\begin{array}{l}\text { Existence of market channel } \\
\text { infrastructure (wholesalers } \\
\text { market, market, warehouse, } \\
\text { licensed warehouse) }\end{array}$ & 7 & $\begin{array}{l}\text { Traditional production of the } \\
\text { product in the region }\end{array}$ & 10 & $\begin{array}{c}\text { Intensity of the product's land } \\
\text { use }\end{array}$ & 7.6 \\
\hline $\begin{array}{l}\text { Ratio of the product's average } \\
\text { yield in the KMRB to its } \\
\text { average yield in Turkey }\end{array}$ & 6 & $\begin{array}{l}\text { Product causes migration from } \\
\text { the KMRB }\end{array}$ & 9 & $\begin{array}{l}\text { Intensity of consumption of } \\
\text { pesticides/chemicals in the } \\
\text { production of the product }\end{array}$ & 7.5 \\
\hline $\begin{array}{l}\text { Public policies in force } \\
\text { prioritizing the product }\end{array}$ & 6 & $\begin{array}{l}\text { Social reputation of the } \\
\text { production activity for the } \\
\text { potential product }\end{array}$ & 9 & $\begin{array}{l}\text { Existence of extensive and } \\
\text { innovative climate-smart } \\
\text { practices suited to the product }\end{array}$ & 7.3 \\
\hline $\begin{array}{l}\text { Existence of contract } \\
\text { production of the product in the } \\
\text { region }\end{array}$ & 6 & $\begin{array}{l}\text { Production of the plant allows } \\
\text { earning of continuous income }\end{array}$ & 9 & $\begin{array}{l}\text { Utilization of fertilizer per } \\
\text { hectare for the production of } \\
\text { the product (in kgN and P2O5) }\end{array}$ & 6.5 \\
\hline
\end{tabular}




\begin{tabular}{|c|c|c|c|c|}
\hline $\begin{array}{c}\text { Geographical indication } \\
\text { transfer }\end{array}$ & 5 & & $\begin{array}{l}\text { Product's green water footprint } \\
\text { in Izmir province }\end{array}$ & 6.2 \\
\hline $\begin{array}{l}\text { Product's suitability for } \\
\text { innovation and technical } \\
\text { advances in the KMRB }\end{array}$ & 5 & & $\begin{array}{l}\text { Ratio of the product's good } \\
\text { agriculture production area to } \\
\text { the product's total cultivation } \\
\text { area in the KMRB }\end{array}$ & 5.7 \\
\hline $\begin{array}{l}\text { Labor productivity of the } \\
\text { product in the KMRB }\end{array}$ & 5 & & $\begin{array}{l}\text { Ratio of the product's organic } \\
\text { production area to the product's } \\
\text { total cultivation area in the } \\
\text { KMRB }\end{array}$ & 5 \\
\hline $\begin{array}{l}\text { Product provides input to } \\
\text { another agricultural product in } \\
\text { the region }\end{array}$ & 5 & & & \\
\hline $\begin{array}{l}\text { Level of mechanization in the } \\
\text { production of the product }\end{array}$ & 5 & & & \\
\hline $\begin{array}{l}\text { Existence of possibilities to } \\
\text { access formal (bank, etc.) } \\
\text { financing }\end{array}$ & 3 & & & \\
\hline TOTAL & $100 \%$ & $100 \%$ & & $100 \%$ \\
\hline
\end{tabular}

\begin{tabular}{l|l}
$\begin{array}{l}\text { Those receiving a high score } \\
\text { (making a positive contribution) gain } \\
\text { a higher rank. }\end{array}$ & $\begin{array}{l}\text { Those receiving a low score obtain a } \\
\text { higher rank (in inverse proportion to } \\
\text { the harm they cause) }\end{array}$ \\
\hline
\end{tabular}

Source: Prepared in the KAPRA study.

\subsection{Selection of Key Agricultural Products in a given region/country}

For the selection of the main agricultural products in a region/country, a comprehensive list of all agricultural products and its different outputs in a given region/country is required. The selection of the key agricultural products will be shown based on the methodology of the KAPRA report. In the Kucuk Menderes River Basin a wide variety of agricultural crops are grown including field crops, vegetables, fruits, animal production and outdoor plants. The final list of agricultural products consists of thirty-four products.

For all 34 products data was collected on the economic, social and environmental impact based on nationally and internationally available statistical data. Where no statistical data was available, expert inputs were used to complement the available data, especially for the analysis of the social and environmental impacts. In a next step the scores obtained for the economic, social and environmental analysis were 
multiplied by the given weights (economic: 34\%, social: 33\% and environmental: 33\%). Table 3.2 shows the outcome of the scoring process for the KAPRA assessment. Thirty-four products have been assessed and the ten products with the highest results are considered the key agricultural products of the Kucuk Menderes River Basin. However, additional information from the field surveys, stakeholder workshops and interviews has also been considered in the KAPRA which modified the list of key agricultural products for which the climate risk analysis was carried out.

Table 3.2 Ranking of agricultural products in the Kucuk Menderes River Basin

\begin{tabular}{|c|c|c|c|c|}
\hline Products & $\begin{array}{c}\text { Result of Economic } \\
\text { Assessment }\end{array}$ & $\begin{array}{c}\text { Result of Social } \\
\text { Assessment }\end{array}$ & $\begin{array}{c}\text { Result of } \\
\text { Environmental } \\
\text { Assessment }\end{array}$ & Total Score \\
\hline Olive (oil) & 44.84 & 38.45 & 49.98 & 44.43 \\
\hline Fig (dried) & 42.35 & 33.78 & 50.83 & 42.32 \\
\hline Cows' milk & 54.84 & 37.51 & 34.07 & 42.27 \\
\hline Grape (wine) & 30.42 & 29.40 & 55.49 & 38.36 \\
\hline Olive (table) & 33.01 & 32.07 & 46.72 & 37.23 \\
\hline Chestnut & 22.30 & 34.32 & 50.24 & 35.49 \\
\hline Tomato (paste) & 46.10 & 41.41 & 12.04 & 33.31 \\
\hline Mandarin (satsuma) & 34.06 & 30.14 & 32.49 & 32.25 \\
\hline Peach & 42.08 & 19.56 & 31.19 & 31.05 \\
\hline Cucumber (table) & 40.68 & 40.62 & 9.05 & 30.22 \\
\hline Grape (dried) & 43.86 & 29.53 & 13.57 & 29.14 \\
\hline Cherry & 34.90 & 24.13 & 27.82 & 29.01 \\
\hline Tomato (table) & 32.47 & 41.40 & 11.72 & 28.57 \\
\hline Lilium & 41.37 & 18.12 & 22.41 & 27.44 \\
\hline Tobacco & 31.11 & 44.56 & 6.48 & 27.42 \\
\hline Potato & 39.86 & 32.32 & 8.69 & 27.08 \\
\hline Black-eyed pea (fresh) & 35.38 & 35.67 & 8.72 & 26.67 \\
\hline Cucumber (pickle) & 39.24 & 31.44 & 8.93 & 26.66 \\
\hline Grape (table) & 36.71 & 29.18 & 13.53 & 26.57 \\
\hline Pepper (capia paste) & 41.62 & 27.39 & 9.21 & 26.23 \\
\hline Okra & 31.12 & 37.88 & 8.89 & 26.01 \\
\hline Pepper (fresh) & 38.88 & 29.14 & 8.38 & 25.60 \\
\hline Lettuce & 27.37 & 33.04 & 16.01 & 25.49 \\
\hline Rose (cut) & 35.86 & 18.24 & 19.58 & 24.67 \\
\hline Bean (fresh) & 31.48 & 32.19 & 9.28 & 24.39 \\
\hline Chrysanthemum & 32.29 & 18.11 & 22.41 & 24.35 \\
\hline Clove & 31.27 & 18.14 & 22.41 & 24.01 \\
\hline Gerbera & 30.08 & 18.09 & 22.41 & 23.59 \\
\hline Cotton (unginned) & 44.91 & 14.51 & 10.11 & 23.39 \\
\hline Artichoke & 26.98 & 26.42 & 11.47 & 21.68 \\
\hline Watermelon & 26.33 & 27.92 & 10.11 & 21.50 \\
\hline Wheat (other) bread & 30.18 & 15.48 & 13.46 & 19.81 \\
\hline Maize (silage) & 33.45 & 11.86 & 8.30 & 18.03 \\
\hline Maize (grain) & 22.63 & 14.49 & 4.98 & 14.12 \\
\hline
\end{tabular}

Source: Prepared in the KAPRA study. 
Table 2.2 shows the top agricultural products in the Kucuk Menderes River Basin. However, in the KAPRA climate change risks were not assessed for the 10 key agricultural products, but only for 5 products. Also, 2 of the 5 key agricultural products do not correspond with the 5 top ranked agricultural products in the region, as other factors were also considered. In the KAPRA report outdoor ornamental plants were also added to the key agricultural products. The importance of outdoor ornamental plants came up during the field analysis, stakeholder workshops and interviews, however, there was insufficient statistical data regarding their production and thus, they were not included in the initial assessment. Due to their rapidly growing importance and the importance of the Basin as a supplier of outdoor ornamental plants to different regions in Turkey, this product was also included in the list of the 5 key agricultural products.

Another product was also added to the list, which is tomato for industrial use. The production of tomato for industrial use has gained a significant place in the Kucuk Menderes River Basin due to its ecosystem, the capacity of production plants and the proximity to harbors and thus, it was decided in the KAPRA assessment to add tomato production for industrial purposes to the study. In conclusion, the following five key agricultural products were identified for the Kucuk Menderes River Basin, taking into account expert opinions and findings from stakeholder workshops: olive (oil), tomato (industrial), cow’s milk, fig (dried) and outdoor ornamental plants (Table 3.3).

Table 3.3: Key agricultural products and their characteristic properties

\begin{tabular}{|l|l|}
\hline Key Agricultural Products & Product characteristic \\
\hline Olive (oil) & Traditional product, grown on highlands, perennial \\
\hline Milk (cow) & Animal product, innovative product \\
\hline Tomato (industrial) & Annual, lowland plant, outdoor production \\
\hline Fig (dried) & Perennial, lowland plant \\
\hline Outdoor ornamental plants & Lowland plant, innovative, greenhouse \& outdoor production \\
\hline
\end{tabular}

\subsection{Assessment of Climate Change Risk for Key Agricultural Products}

\subsubsection{Assessment of Climate Change Risk}

There are several risks from climate change which will have a direct impact on the agricultural sector such as average temperature, number of extremely hot and cold days, drought, relative humidity, precipitation regime and amount, sea level, hail, frost, wind speed, soil structure and salinity, structure and quantity of weed. The effects of climate change on a region/country need to be studied in detail before an assessment of climate change risk for key agricultural products can be carried out. Since a wide variety of significant risks are encountered in agriculture, in the KAPRA assessment, the weather- and climate-related risks that were taken into account within the scope of the available data are as follows:

- Changes in the precipitation regime

- Changes and variations in air temperatures (e.g. extreme and high minimum and maximum temperature records, etc.)

- Hailstorms

- Drought events

- Frost events 
To start, firstly the current climatology of the KMRB was determined and then the risks arising from climate change until 2050 were evaluated. Then, an agricultural vulnerability assessment ${ }^{12}$ was conducted using the weather- and climate-related risks identified as well as economic and social indicators.

Figure 3.3 Flowchart of agricultural vulnerability assessment

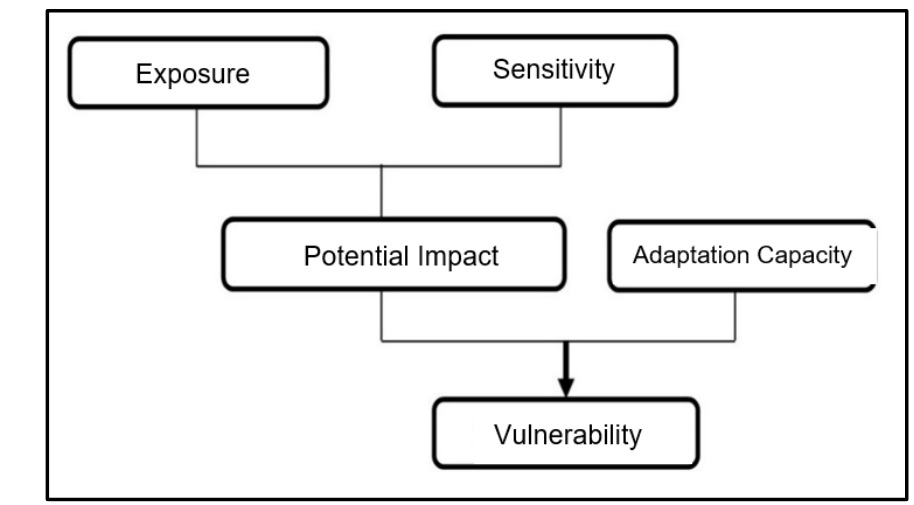

Source: Fellman, 2012; Füssel and Klein, 2006

Dimensions of the agricultural vulnerability assessment are exposure, sensitivity, vulnerability, and adaptation capacity (Figure 3.3). Exposure is related to "the nature and degree to which a system is exposed to significant climatic variations". Sensitivity is related to "the degree to which a system is affected", either beneficially or adversely by climate variability or change. The effect may be direct (e.g., a change in crop yield in response to a change in the mean, range or variability of temperature) or indirect (e.g., damages caused by an increase in the frequency of coastal flooding due to sea-level rise)" (IPCC 2001). Adaptation Capacity is the ability of institutions and individuals to avoid potential damage, to take advantage of opportunities or to overcome due to the change. The most difficult aspect of vulnerability, due to many socio-economic variables, is to determine the adaptive capacity. Local knowledge obtained, and methods applied, relating to the matter, by farmers, tree farmers (e.g., "Forest Villagers in Turkey), and fishermen (especially those who make traditional small local fishery) over time are vital in terms of the adaptation capacity. (Türkeş, 2017b). Vulnerability can be defined in the broadest sense as "the relationship between the degree of being affected by or impressionability to climate change stress, level of compensation of or responding to this stress (sensitivity or susceptibility), and level of adaptation to climate changes (adaptability), of a community or system”.

The list of indicators which were used in the vulnerability assessment are presented Table 3.4 below.

Table 3.4: List of indicators

\begin{tabular}{|c|c|c|c|c|c|}
\hline & Exposure & & Sensitivity & & Adaptive Capacity \\
\hline E2 & Change in Temperature & $\mathrm{H} 2$ & Soil organic substance (\%) & A1 & Product diversification \\
\hline E3 & Change in Precipitation & H3 & Soil phosphorus (mg $100 \mathrm{~g}-1$ ) & $A 3$ & Insurance \\
\hline E4 & $\begin{array}{l}\text { Variation in Precipitation in } \\
\text { Winter and Spring }\end{array}$ & $\begin{array}{l}\mathrm{H} 4 \\
\mathrm{H} 5\end{array}$ & $\begin{array}{l}\text { Soil pH (hm3/year) } \\
\text { Groundwater availa }\end{array}$ & A2 & $\begin{array}{l}\text { Consumed } \quad \text { fertilizer } \\
(\mathrm{kg} / \text { decare })\end{array}$ \\
\hline E5 & $\begin{array}{l}\text { Variation in number of days } \\
\text { with frost }\end{array}$ & H1 & $\begin{array}{l}\text { (dimensionless) } \\
\text { Farmlands (\%) }\end{array}$ & & $\begin{array}{l}\text { (standardized sum of } \\
N, P \text {, and } K \text { from the }\end{array}$ \\
\hline E1 & $\begin{array}{l}\text { Farming areas (ha) affected } \\
\text { from hailstorm }\end{array}$ & H6 & & & additional fertilizer) \\
\hline
\end{tabular}

\footnotetext{
${ }^{12}$ It needs to be noted that when evaluating and mapping the agricultural vulnerability utmost care should be taken because of uncertainties regarding the method. The results may be quite different from each other.
} 
Source: Adapted by authors from Füssel and Klein, 2006

Data listed in Table 3.4 was obtained from MGM, Turkish Statistical Institute (TURKSTAT), Agricultural Insurance Pool (TARSIM) and Turkish Ministry of Agriculture and Forestry. Selected 13 different adaptation capacity indicators which are widely used in the literature are given below.

- Unemployment rate

- Social welfare payment

- Farmland

- Farm incomes

- Number of farms

- Number of elder employees

- Dependency rate

- Internal migration

- Average yield of all crops

- Access to storm forecast information

Since the adaptation capacity indicators listed above could not be obtained on the district basis, they could not be used in this study.

Table 3.5 shows the agriculture vulnerability assessment which has been carried out for the KMRB in today's climatic conditions by using the indicators given in Table 3.4 above.

Table 3.5: Vulnerability levels which were calculated for the districts in the Kucuk Menderes Basin

\begin{tabular}{|l|c|c|c|c|c|c|c|c|}
\hline & \multicolumn{2}{|c|}{ EXPOSURE } & \multicolumn{2}{c|}{ SENSITIVITY } & ADAPTATION CAPACITY & \multicolumn{2}{c|}{ VULNERABILITY } \\
\hline & Total Index & Percent & Total Index & Percent & Total Index & Percent & $\begin{array}{c}\text { Index Arithmetic } \\
\text { Mean }\end{array}$ & Percent \\
\hline Bayindir & 2.32 & 46.40 & 3.33 & 55.50 & 2.14 & 71.33 & 2.60 & 55.64 \\
\hline Beydag & 2.81 & 56.20 & 4.69 & 78.17 & 0.83 & 27.67 & 2.78 & 59.50 \\
\hline Kiraz & 2.87 & 57.40 & 4.03 & 67.17 & 1.11 & 37.00 & 2.67 & 57.21 \\
\hline Menderes & 1.61 & 32.20 & 2.77 & 46.17 & 2.58 & 86.00 & 2.32 & 49.71 \\
\hline Odemis & 2.14 & 42.80 & 3.17 & 52.83 & 2.38 & 79.33 & 2.56 & 54.93 \\
\hline Selcuk & 1.13 & 22.60 & 2.56 & 42.67 & 1.23 & 41.00 & 1.64 & 35.14 \\
\hline Tire & 2.55 & 51.00 & 3.06 & 51.00 & 2.73 & 91.00 & 2.78 & 59.57 \\
\hline Torbalı & 1.90 & 38.00 & 2.68 & 44.67 & 2.98 & 99.33 & 2.52 & 54.00 \\
\hline
\end{tabular}

The vulnerability percentages were grouped according to the following class intervals (Ravindranath et al., 2011).

- Very low: $0 \leq$ Percentage $<20$

- Low: $20 \leq$ Percentage $<40$

- Medium: $40 \leq$ Percentage $<60$

- High: $60 \leq$ Percentage $<80$

- Very high: $80 \leq$ Percentage $<100$

Except for the districts of Selcuk and Torbal1, the districts in the KMRB are at medium category/level in terms of exposure to the impacts of climate change under current conditions. When the indicators were examined, the index values in Selcuk and Torbalı were low since these districts were less exposed to the 
impacts of the production areas affected by the change in precipitation, change in winter and spring precipitation, and hailstorm. When the adaptation capacity index values were examined, it was determined that the districts in KMRB, in general, are listed between low and very high level in terms of adaptation to the agricultural effects of climate change. Due to the excessive fertilizer consumption in Beydag and the lack of product diversification and insurance penetration percentages, the adaptation capacity was found to be low. It is important to keep in mind that only three indicators were used in this evaluation since no data on the district basis was found for the remaining indicators.

The following paragraph provides an example of the basic results regarding the effects of climate change on the KMRB to set the stage for the following climate change risk assessment for key agricultural products in the Basin. For the evaluation of the future situation, present and future climatic working conditions and future drought conditions were examined through the Heat Index and Standardized Precipitation Index (SPI) respectively. As per heat indices calculated for 1940-2050 for the KMRB, August and July heat index values after 2022 are in "extreme attention/hazard zone”. In addition, slight and moderate drought conditions have prevailed in the region after the 90s as per SPI. It is predicted that according to SPI values, severe and extreme drought conditions will be seen as of 2030 which means the prevalence of drought conditions continues to increase and aridification tendency will strengthen. This could be seen as a sign of hydrological drought, probable agricultural drought events and gradual increase in water deficit in the KMRB. As a result of this, a sharp decrease is expected in the levels of groundwaters, rivers, and lakes. Also, it is obvious that during the growth period, there will be insufficient soil moisture in a certain critical period during which a particular plant needs water. Regarding rises in sea level, when the sea level rises by 10 meters, the sea water transgresses towards the inland areas by $16-20 \mathrm{~km}$ and covers a significant part of the district of Selcuk. However, a maximum of $32 \mathrm{~cm}$ sea water rise is estimated by 2050 and a maximum sea level rise of $88 \mathrm{~cm}$ by 2100. Even in the most unfavorable situation, sea water transgresses by $1-2 \mathrm{~km}$ in a small inland area. In this case, the sea water rise does not pose a surface risk for the KMRB.

In summary, projections for climate change risk in the KMRB state that temperatures will rise between $2^{\circ} \mathrm{C}$ and $6^{\circ} \mathrm{C}$ toward the end of the $21^{\text {st }}$ century. The change in precipitation is only expected to be marginal, amounting to less than 5\% until 2050, however drought periods between rainfalls are expected to become longer. After the year 2022, continuous drought conditions (to a moderate or extreme extent) are anticipated. After 2022 severe water shortage is also anticipated in the Kucuk Menderes River Basin, with the steepest falls to be expected between 2051 and 2060 - when only 36\% of the required water will be supplied from within the Basin). The agricultural sector is the main user of water resources, and, thus, this prediction poses a major threat to agriculture. The rise of sea levels will be minimal, and, thus, is expected not to pose a threat to agriculture.

\subsubsection{Climate Change Risk Assessment for Key Agricultural Products}

Depending on data availability the risks resulting from climate change were analyzed for each of the 5 key agricultural products of the KAPRA to determine the potential loss of function of the products as well as the changes in yield and quality of the selected products. For this purpose, the products were analyzed along their production chain, i.e. the whole process a product goes through was studied, from the beginning of its production to the delivery of the product to the end consumer. The result of this process is a "production chain map" which shows the loss of value of a product resulting from climate change. Multiple stakeholders from different stages of the production chain (producers, input providers, processors, commissioners, 
wholesalers and retailers) were interviewed and the results were supported by expert opinions and by the results of previous studies. The methodology of the climate change risk analysis will now be illustrated by the case of olives, one of the five key agricultural products of the KAPRA.

\subsubsection{Example of olive production (for oil)}

A climate risk analysis for key agricultural products will be shown with the example of the production of olive (for oil) in the Kucuk Menderes River Basin from the KAPRA. Figure 3.4 shows the production chain diagram for olive oil in the Kucuk Menderes River Basin, which is the result of the analysis of the production chain for olive oil.

Figure 3.4 Production chain diagram for olive oil production in the Basin

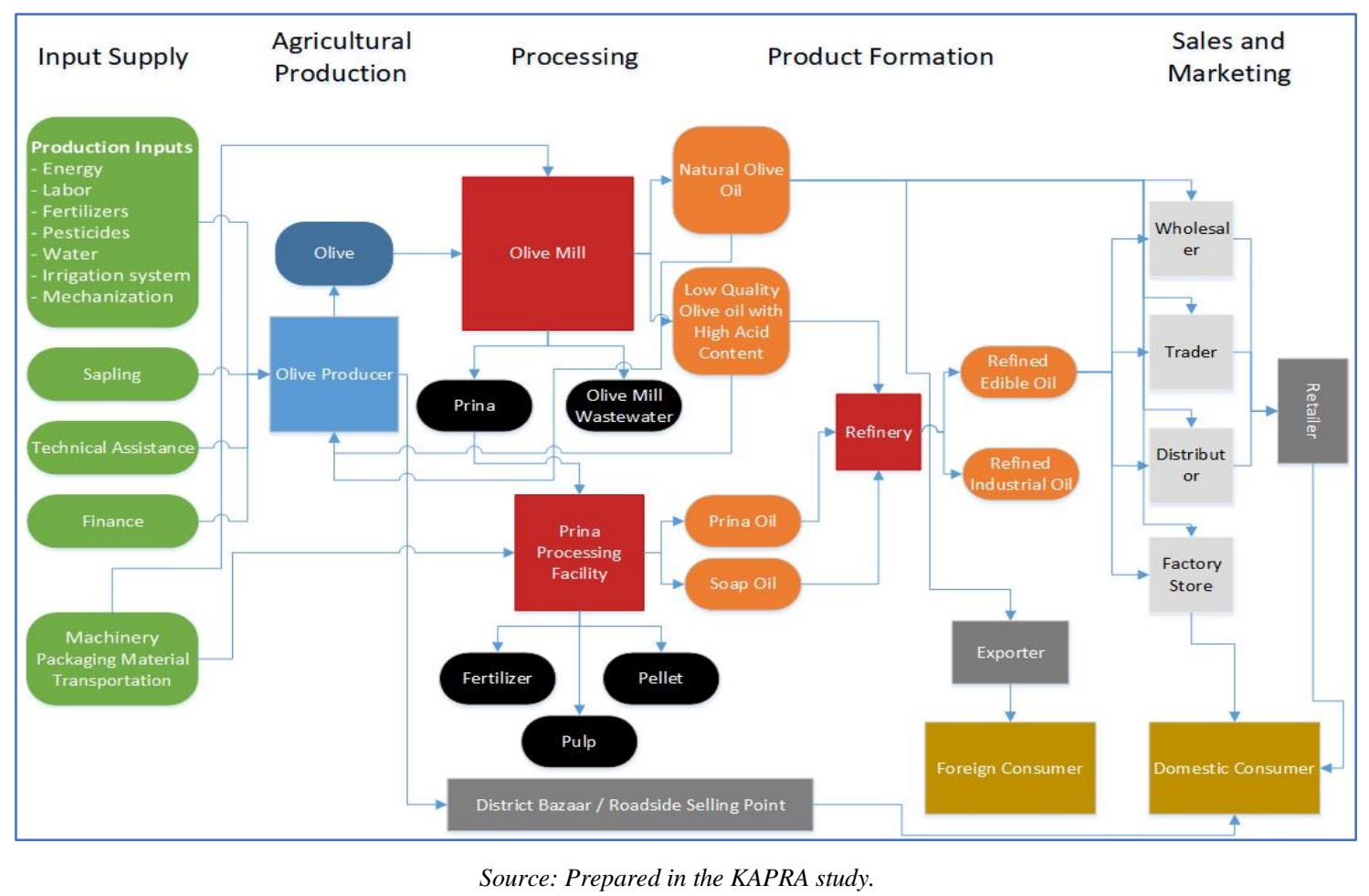

The diagram shows the required production inputs (energy, labor, fertilizers, pesticides, water, irrigation system and mechanization) as well as the steps required in the production of olive oil ranging from the agricultural production to the processing and the product formation all the way to the sale and marketing of the final product. The production chain diagram helps to identify all the steps of the production process which are then analyzed regarding the risks and effects of climate change.

Table 3.6 shows the analysis of the predicted effects of climate change on the olive oil production chain between 2021 and 2050. The analyzed climate change factors are separated into various different scenarios such as variation in average temperature, excessive cold, excessive heat, temperature rise during winter, precipitation, snowfall, relative humidity, fog, hail, wind speed and direction as well as carbon dioxide decrease. Each climate change factor is then analyzed regarding the following aspects of the olive oil production: supply of input, impact on olive production, impact on yield, impact on quality, impact on olive oil processing industry as well as marketing and sales. In a final step, suggestions are also provided regarding the adaptation capacity of the plants or the production conditions for each climate change factor. 
3.6 Effects of climate change on the olive oil production chain between 2021 and 2051

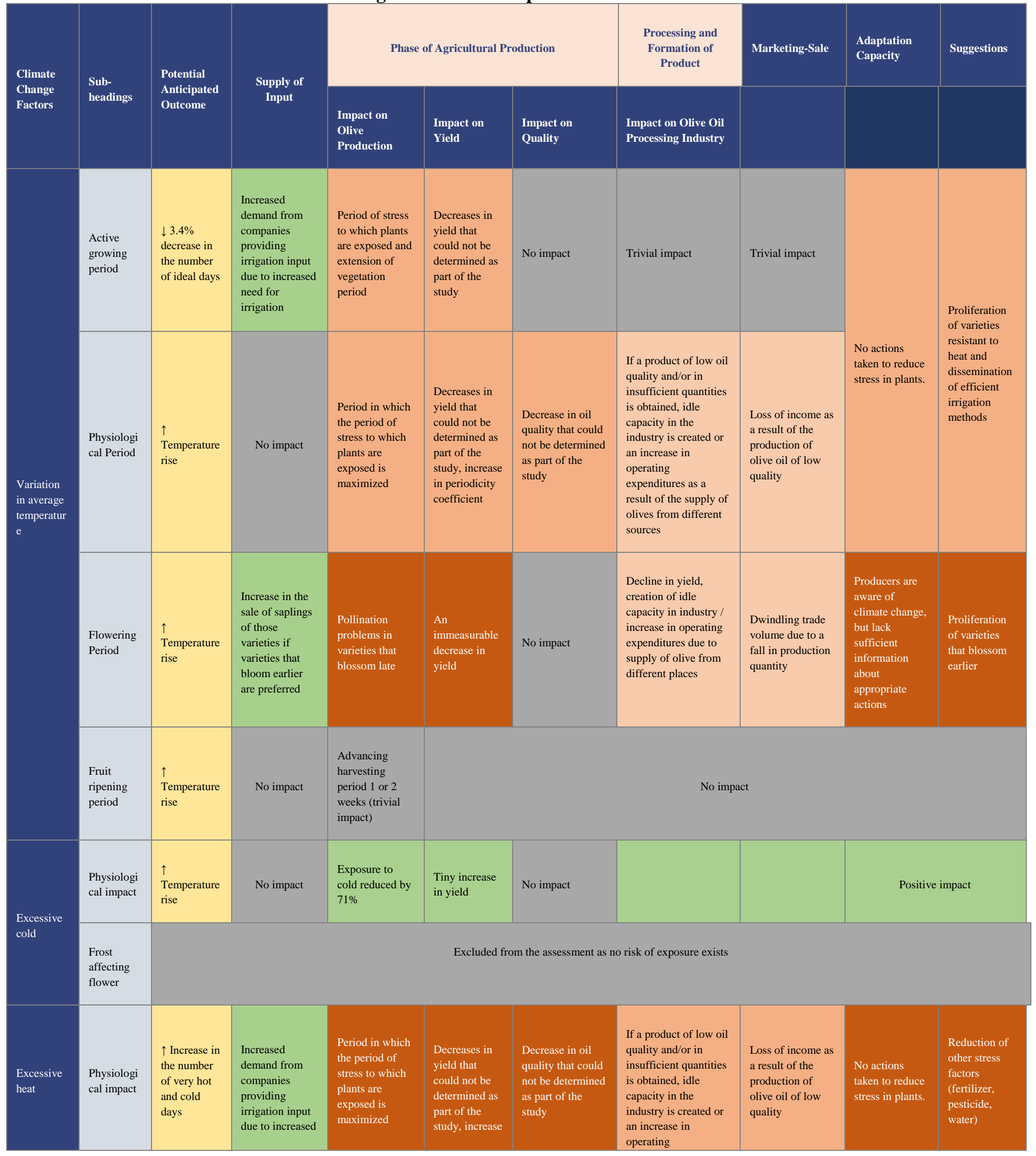




\begin{tabular}{|c|c|c|c|c|c|c|c|c|c|c|}
\hline & & & $\begin{array}{l}\text { need for } \\
\text { irrigation }\end{array}$ & & $\begin{array}{l}\text { in periodicity } \\
\text { coefficient }\end{array}$ & & $\begin{array}{l}\text { expenditures as a } \\
\text { result of the supply of } \\
\text { olives from different } \\
\text { sources }\end{array}$ & & & \\
\hline $\begin{array}{l}\text { Temperatu } \\
\text { re rise } \\
\text { during } \\
\text { winter }\end{array}$ & $\begin{array}{l}\text { Need to } \\
\text { cool off }\end{array}$ & $\begin{array}{l}\downarrow \text { Decline in } \\
\text { cooling } \\
\text { period by up } \\
\text { to } 50 \%\end{array}$ & $\begin{array}{l}\text { Rise in demand } \\
\text { for saplings of } \\
\text { varieties with } \\
\text { low cooling } \\
\text { need }\end{array}$ & $\begin{array}{l}\text { Low yield of } \\
\text { varieties with } \\
\text { high cooling } \\
\text { need, loss of } \\
\text { variety and trees }\end{array}$ & $\begin{array}{l}\text { Serious } \\
\text { decreases in } \\
\text { yield that } \\
\text { could not be } \\
\text { determined as } \\
\text { part of the } \\
\text { study }\end{array}$ & No impact & $\begin{array}{l}\text { As a result of serious } \\
\text { decline in yield, the } \\
\text { creation of idle } \\
\text { capacity in the sector } \\
\text { or the increase in } \\
\text { operating } \\
\text { expenditures due to } \\
\text { the supply of olives } \\
\text { from different sources }\end{array}$ & $\begin{array}{l}\text { Significant } \\
\text { decline in trade } \\
\text { volume in case of } \\
\text { idle capacity in } \\
\text { the sector }\end{array}$ & $\begin{array}{l}\text { Producers lack } \\
\text { awareness of } \\
\text { the need of } \\
\text { cooling }\end{array}$ & $\begin{array}{l}\text { Development } \\
\text { and } \\
\text { proliferation } \\
\text { of varieties } \\
\text { that have a } \\
\text { low cooling } \\
\text { need, low } \\
\text { periodicity } \\
\text { coefficient, } \\
\text { low oil } \\
\text { content and } \\
\text { resistant to } \\
\text { drought }\end{array}$ \\
\hline \multirow[b]{2}{*}{$\begin{array}{l}\text { Precipitati } \\
\text { on }\end{array}$} & $\begin{array}{l}\text { Physiologi } \\
\text { cal impact }\end{array}$ & $\begin{array}{l}\downarrow 3.07 \% \\
\text { decrease in } \\
\text { precipitation }\end{array}$ & & $\begin{array}{l}\text { Increase in plant } \\
\text { stress during } \\
\text { phenological } \\
\text { periods }\end{array}$ & $\begin{array}{l}\text { Slight fall in } \\
\text { harvest }\end{array}$ & $\begin{array}{l}\text { Slight decrease in } \\
\text { oil quality }\end{array}$ & $\begin{array}{l}\text { If a product of low oil } \\
\text { quality and/or in } \\
\text { insufficient quantities } \\
\text { is obtained, creation } \\
\text { of idle capacity in the } \\
\text { sector or increases in } \\
\text { operating } \\
\text { expenditures as a } \\
\text { result of the supply of } \\
\text { olives from different } \\
\text { sources }\end{array}$ & $\begin{array}{l}\text { Loss of income as } \\
\text { a result of the } \\
\text { production of } \\
\text { olive oil of low } \\
\text { quality }\end{array}$ & $\begin{array}{l}\text { Insufficient } \\
\text { terracing of } \\
\text { olive trees } \\
\text { planted in the } \\
\text { Basin }\end{array}$ & $\begin{array}{l}\text { Mulching and } \\
\text { terracing to } \\
\text { prevent water } \\
\text { loss from soil }\end{array}$ \\
\hline & $\begin{array}{l}\text { Need for } \\
\text { irrigation } \\
\text { water }\end{array}$ & $\begin{array}{l}\uparrow 5.83 \% \\
\text { increase in } \\
\text { the plant’s } \\
\text { water need }\end{array}$ & $\begin{array}{l}\text { Increased } \\
\text { demand from } \\
\text { companies } \\
\text { providing } \\
\text { irrigation input } \\
\text { due to the } \\
\text { increased need } \\
\text { for irrigation, } \\
\text { increased } \\
\text { energy demand }\end{array}$ & $\begin{array}{l}\text { Increase in } \\
\text { water stress } \\
\text { Drying trees, } \\
\text { branches and } \\
\text { leaves; } \\
\text { dwindling water } \\
\text { source; } \\
\text { retracting well } \\
\text { waters; energy } \\
\text { and cost } \\
\text { increases }\end{array}$ & $\begin{array}{l}12.6 \% \text { yield } \\
\text { loss in dry } \\
\text { conditions, } \\
5 \% \text { yield loss } \\
\text { based on } \\
\text { existing } \\
\text { conditions }\end{array}$ & $\begin{array}{l}\text { Decrease in oil } \\
\text { quality }\end{array}$ & $\begin{array}{l}\text { If a product of low oil } \\
\text { quality and/or in } \\
\text { insufficient quantities } \\
\text { is obtained, the } \\
\text { creation of idle } \\
\text { capacity in the sector } \\
\text { or increases in } \\
\text { operating } \\
\text { expenditures as a } \\
\text { result of the supply of } \\
\text { olives from different } \\
\text { sources }\end{array}$ & $\begin{array}{l}\text { Loss of income as } \\
\text { a result of the } \\
\text { production of } \\
\text { olive oil of low } \\
\text { quality }\end{array}$ & $\begin{array}{l}\text { Extensiveness } \\
\text { of surface } \\
\text { irrigation; lack } \\
\text { of modern and } \\
\text { pressurized } \\
\text { irrigation } \\
\text { infrastructure }\end{array}$ & $\begin{array}{l}\text { Drip } \\
\text { irrigation, } \\
\text { closed-system } \\
\text { irrigation, } \\
\text { prevention of } \\
\text { evaporation } \\
\text { from in ponds } \\
\text { and soil }\end{array}$ \\
\hline Snowfall & $\begin{array}{l}\text { Mechanica } \\
\text { l effect }\end{array}$ & $\begin{array}{l}\downarrow \text { Decrease } \\
\text { in snowfall }\end{array}$ & No impact & $\begin{array}{l}\text { Decrease in } \\
\text { branch breakage }\end{array}$ & $\begin{array}{l}\text { No direct } \\
\text { impact }\end{array}$ & & & & \multirow{2}{*}{\multicolumn{2}{|c|}{ Positive impact }} \\
\hline $\begin{array}{l}\text { Relative } \\
\text { humidity }\end{array}$ & Pollination & $\begin{array}{l}\downarrow 1.3 \% \\
\text { decrease in } \\
\text { relative } \\
\text { humidity }\end{array}$ & $\begin{array}{l}\text { Decline in } \\
\text { pesticide } \\
\text { demand }\end{array}$ & $\begin{array}{l}\text { Positive effect } \\
\text { during } \\
\text { flowering } \\
\text { period, positive } \\
\text { effect on } \\
\text { decrease in } \\
\text { diseases }\end{array}$ & $\begin{array}{l}\text { Tiny increase } \\
\text { in yield }\end{array}$ & No direct impact & Trivial impact & Trivial impact & & \\
\hline Fog & Pollination & \multicolumn{9}{|c|}{ There was no data available for a study of climate change } \\
\hline Hail & $\begin{array}{l}\text { Flower and } \\
\text { fruit, leaf } \\
\text { damage }\end{array}$ & $\begin{array}{l}\uparrow \text { Relative } \\
\text { increase in } \\
\text { hail } \\
\text { incidence } \\
\text { due to } \\
\text { increase in } \\
\text { climatic }\end{array}$ & No impact & $\begin{array}{l}\text { Leaf, branch } \\
\text { fruit loss }\end{array}$ & $\begin{array}{l}\text { Slight } \\
\text { decrease in } \\
\text { yield }\end{array}$ & $\begin{array}{l}\text { Slight effect } \\
\text { decreasing quality }\end{array}$ & Trivial impact & Trivial impact & $\begin{array}{l}\text { Rise in } \\
\text { awareness of } \\
\text { agricultural } \\
\text { insurance }\end{array}$ & $\begin{array}{l}\text { Agriculture } \\
\text { insurance }\end{array}$ \\
\hline
\end{tabular}



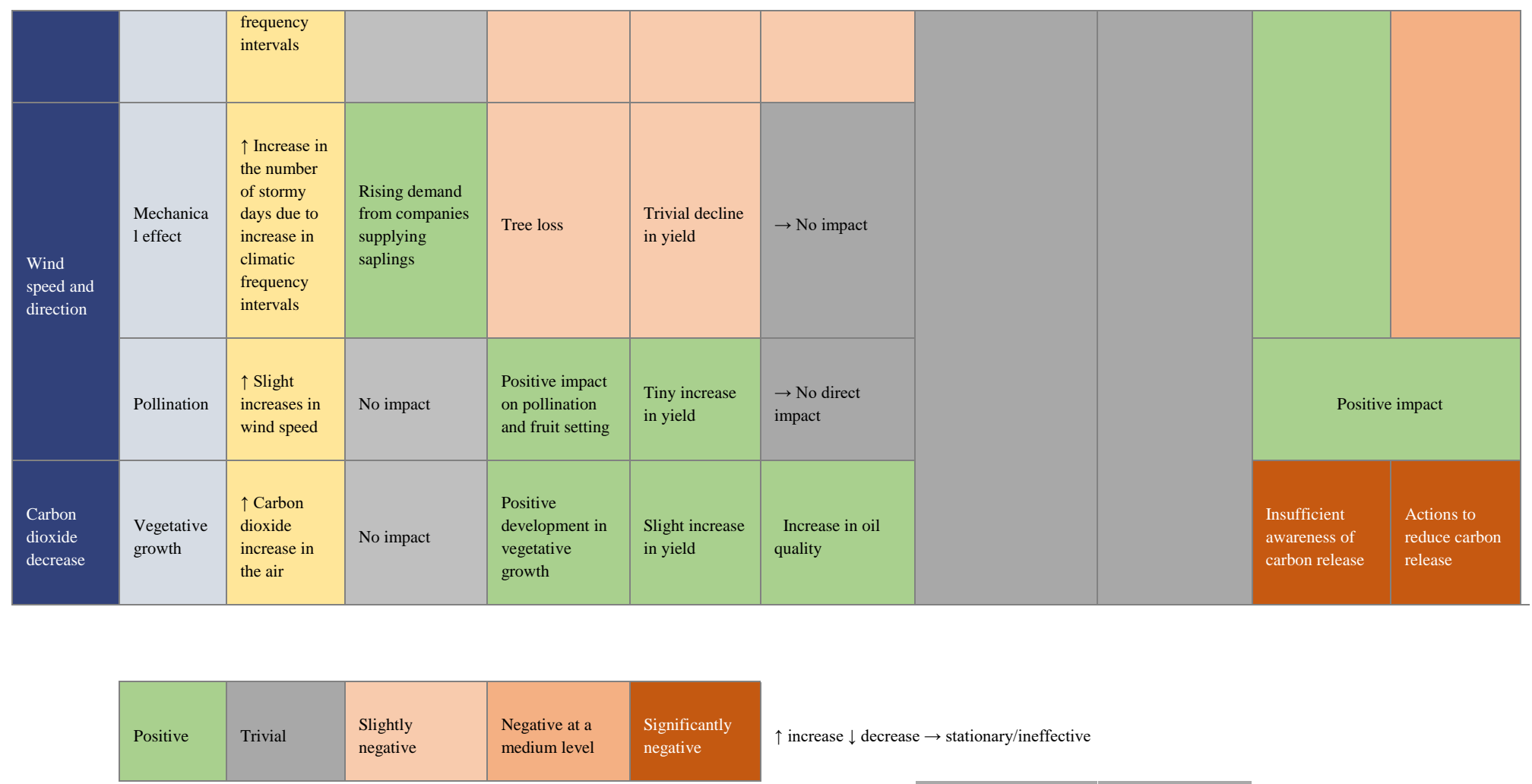

Source: Prepared in the KAPRA study.

In summary, the climate change risk assessment for the production of olive oil has shown a few positive effects, but most of the expected effects from climate change are negative. It is expected that an increase in average temperatures and the number of very hot days and an expected $3.1 \%$ decrease in the quantity of precipitation as well as low cooling periods will lead to a critical situation for certain olive varieties and a decrease in the yield of olive production. Thus, the results of the KAPRA assessment show that the fall in olive yield is expected to be between $10-20 \%$. Assuming that all other factors such as market, price and production culture, remain unchanged, the loss of value is estimated to be between TRY 16-32 million in the primary production phase. After industrial processing, the loss is expected to be between TRY 20-40 million. Table 2.4 shows more detailed calculations for the cases of a $10 \%, 15 \%$ and $20 \%$ harvest loss in olives.

Considering climate change projections for the Basin - although positive effects are mentioned - increases in the number of very hot days and average temperatures, a 3.1\% decrease in the quantity of average precipitation, and low cooling periods that fail to meet the needs of some olive varieties combine to create a critical situation for olive yield. As a result, olive yield is predicted to fall by between $10 \%$ and $20 \%$ in the best-case scenario unless action is taken by 2050. Assuming no changes in other factors, the loss of value based on current 2017 prices is estimated to be between TRY 16.2-32.2m in the primary production phase, and between TRY 19.8m and TRY 39.6m after industrial processing (Table 3.7). 
Table 3.7 Olive Oil Production Chain in the KMRB, in case of harvest loss

\begin{tabular}{|c|c|c|c|c|c|c|}
\hline Production Phase & Product & $\begin{array}{c}\text { Existing } \\
\text { Production } \\
\text { Quantity } \\
\text { (tonnes) }\end{array}$ & $\begin{array}{l}\text { Existing } \\
\text { Production } \\
\text { Value } \\
\text { (thousand } \\
\text { TRY) }\end{array}$ & $\begin{array}{c}10 \% \\
\text { Harvest } \\
\text { Decrease } \\
\text { (thousand } \\
\text { TRY) }\end{array}$ & $\begin{array}{c}15 \% \\
\text { Harvest } \\
\text { Decrease } \\
\text { (thousand } \\
\text { TRY) }\end{array}$ & $\begin{array}{c}20 \% \\
\text { Harvest } \\
\text { Decrease } \\
\text { (thousand) } \\
\text { TRY }\end{array}$ \\
\hline Primary Production & Olive Grown for Oil & $65,781.12$ & $154,585.63$ & $138,482.96$ & $130,431.63$ & $122,380.29$ \\
\hline \multirow{3}{*}{ Olive Oil Production } & Natural Olive Oil & $12,498.41$ & $170,415.86$ & $152,664.21$ & $143,788.38$ & $134,912.55$ \\
\hline & Table Olive Oil of Low Quality & 657.81 & $6,643.89$ & $5,951.82$ & $5,605.78$ & $5,259.75$ \\
\hline & Pomace oil & $29,601.50$ & $1,118.94$ & $1,002.38$ & 944.10 & 885.83 \\
\hline \multirow{3}{*}{ Pomace oil processing } & Table Pomace Oil & 888.05 & $4,795.44$ & $4,295.92$ & $4,046.16$ & $3,796.39$ \\
\hline & Industrial Pomace Oil & $1,184.06$ & $3,836.35$ & $3,436.73$ & $3,236.92$ & $3,037.11$ \\
\hline & Pomace Olive Wood & $16,280.83$ & $4,395.82$ & $3,937.93$ & $3,708.98$ & $3,480.03$ \\
\hline \multicolumn{3}{|l|}{ Total } & $190,087.37$ & $170,286.61$ & $160,386.22$ & $150,485.84$ \\
\hline
\end{tabular}

Source: Prepared in the KAPRA study.

Resulting from the possible decline in olive production, there are also further associated risks. There might be a risk of idle capacity for olive oil processing and the fall in the production quantity might lead to an increase in the price for olive oil. This would lead to a decrease in the competitiveness of olive oil produced in the Basin. At the same time, a decline in the quality of olive oil might lead to a loss in income for the farmers.

Impacts of potential climate change on other areas that may also lead to change in agricultural production in the Basin are shown below:

- Effect of Climate Change on Weed Control: Controlling weeds due to the climate change may require additional chemical pesticides. A decline in the effectiveness of herbicides may increase the need of mechanical control, and this may be reflected in the products through more labor requirements and increased costs. A reduction in precipitation in the KMRB by up to 3.1\% by 2050 will, however, not lead to a significant vulnerability to weeds as per projections.

- Impact of Climate Change on Soil Structure: Temperature and precipitation affect soil formation by determining both the physical and chemical decomposition and the type of vegetation. Only a detailed and long-term study could determine the role played by climate change in a transformation involving so many interrelated factors. Under KAPRA, a risk projection was made in which the two soil parameters that are critical to the production of selected products were analyzed based on the climate change scenario in question.

o Soil Salinity: Salinity in soil and irrigation water has become even more important in changing climate. Salt is not washed away in semi-arid areas and accumulated in the topsoil due to rising temperatures and falling precipitation. The risk of salinity is aggravated as water is extracted from much deeper sections of wells. This phenomenon restricts the development of plant roots and causes abiotic stress in plants. Thus, species that are resistant to salinity should be selected for agricultural activities in areas affected by salinity problems (Dölarslan et al., 2017). The entire Basin, aside from the coastal part of Selçuk district and the southwestern parts of Odemis district, has salinity-free soil or 
very low salinity. While salinity levels will increase as irrigable agricultural land receives less precipitation, a high level of vulnerability resulting from climate change is not expected to be observed in soil salinity in other regions until 2050.

o Soil pH and Alkalinity: As no drastic decline in precipitation in the Basin is anticipated, no noteworthy change in soil $\mathrm{pH}$ is expected to occur until the 2050s. A rise in temperature may lead to changes in the soil $\mathrm{pH}$ via capillary tubes in the soil.

- Impact of Climate Change on Diseases, Pests and Bee Populations: As per the projections, fungal disease can be seen in the Basin which may lead to loss in yield and decrease iquality in the future. There are shortcomings in the collective fight against diseases and pests in vegetative production in the Basin. Potential increases in fall temperatures and humidity may directly affect the development of honey bees and create problems in wintering and different stress points. Apiculture is not a common agricultural activity in the Basin, and this will be a critical issue for agricultural products that need bees for growth (Şahinler et al., 2008.)

\subsection{Identifying resilience solutions}

\subsubsection{Methodology}

The KAPRA report also provided solutions for increasing resilience to the identified risks from climate change in the agricultural sector by developing business cases. Many of the business cases which were developed provide solutions to more than one product. Priority was given to those climate change risks which will happen in the nearer future and, thus, provide less uncertainty than those risks which were only predicted for the end of the century. The proposed solutions focus on all parts of the production chain. The KAPRA includes both solutions with a focus on climate change adaptation as well as climate change mitigation.

For each climate change risk that was analyzed, one or more business solutions have been presented in the KAPRA. Among others, the following factors were analyzed: (i) Key product(s) affected; (ii) Climate parameter targeted for adaptation; (iii) Description of the solution and its goals; (iv) Implementation steps; (v) Links of value chain affected; (vi) Nature of solution (adaptation/mitigation/structural improvement); and (vii) Scale of implementation. The financial data was also analyzed and financing solutions were proposed for each business case, covering, among others, the following areas: (i) Total financing requirement (USD); (ii) Projected implementation period (years); (iii) Number of beneficiaries (Individual or Business); (vi) Period during which the solution will reduce climate risk for each beneficiary (years); (v) Anticipated yield increase/cost decrease; (vi) Anticipated ideal financing strategy.

\subsubsection{Example}

The KAPRA 20 business cases have been developed. The resilience solutions proposed by the KAPRA will be shown based on two examples for the production of olive (oil). The two business solutions address the following finding on climate change: Cooling, which is needed by certain olive varieties, will continue to fall up to $50 \%$ which is due to increasing temperatures in winter. Thus, the cooling requirements for some olive varieties will not be met anymore and olive yields will decrease. The two business solutions proposed are the following: (1) Extension of new olive varieties which are of high quality, resistant to drought and 
suitable for machine harvesting; (2) Replacing of local olive varieties in the region which are vulnerable to climate change. Table 3.8 gives an overview of the two business cases, including financing solutions.

Table 3.8: Resilience and Finance Solutions for Two Cases of the Production of Olive (Oil)

\begin{tabular}{|c|c|c|}
\hline & $\begin{array}{l}\text { (1) Extension of new olive } \\
\text { varieties which are of high } \\
\text { quality, resistant to drought and } \\
\text { suitable for machine harvesting }\end{array}$ & $\begin{array}{l}\text { (2) Replacing of local olive varieties } \\
\text { in the region which are vulnerable } \\
\text { to climate change }\end{array}$ \\
\hline Key product(s) affected & Olive (for oil) & Olive (for oil) \\
\hline $\begin{array}{l}\text { Climate parameter targeted for } \\
\text { adaptation }\end{array}$ & $\begin{array}{l}\text { Cooling need (increase in winter } \\
\text { temperatures) and temperature rise } \\
\text { during flowering period }\end{array}$ & $\begin{array}{l}\text { Cooling need (increase in winter } \\
\text { temperatures) and temperature rise } \\
\text { during flowering period }\end{array}$ \\
\hline $\begin{array}{l}\text { Description of the solution and its } \\
\text { goals }\end{array}$ & $\begin{array}{l}\text { Setting up an in vitro laboratory and } \\
\text { production station for saplings and } \\
\text { virus-free materials of varieties such } \\
\text { as Arbeqina I-18 and similar that } \\
\text { need less cooling, that provide high } \\
\text { quality olive oil and that are suitable } \\
\text { for mechanized agriculture (1), } \\
\text { providing support to growers to } \\
\text { enable them to set up groves and } \\
\text { nurseries for saplings to extend } \\
\text { production (2) and offering support } \\
\text { covering harvesting and pruning } \\
\text { machines suited to those species (3). }\end{array}$ & $\begin{array}{l}\text { Transforming existing olive varieties } \\
\text { that have a high cooling need, low oil } \\
\text { quality and high periodicity into } \\
\text { varieties that have lower periodicity, } \\
\text { low cooling need and high yield } \\
\text { through grafts. }\end{array}$ \\
\hline Implementation steps & $\begin{array}{l}\text { Supply of initial disease-free } \\
\text { varieties, installation of laboratory } \\
\text { (or utilization of the laboratories of } \\
\text { existing university/research institute } \\
\text { laboratories), sapling reproduction, } \\
\text { development of a design for a grove } \\
\text { facility with clone rootstock, } \\
\text { distribution of saplings and } \\
\text { allocation of grove facility } \\
\text { (including drip irrigation), training } \\
\text { of farmers for application and care, } \\
\text { procurement of harvesting and } \\
\text { pruning machinery (self-propelled) }\end{array}$ & $\begin{array}{l}\text { Training, awareness activities, } \\
\text { grafting on farms }\end{array}$ \\
\hline Links of value chain affected & $\begin{array}{l}\text { Input suppliers, Cooperatives, } \\
\text { Sapling growers, Farmers, } \\
\text { Processors of Olive for Oil } \\
\text { Production, Consumers }\end{array}$ & Olive oil processors and exporters \\
\hline
\end{tabular}




\begin{tabular}{|c|c|c|}
\hline $\begin{array}{l}\text { Nature of } \quad \text { solution } \\
\text { (adaptation/mitigation/structural } \\
\text { improvement) }\end{array}$ & Adaptation & Adaptation \\
\hline Scale of implementation & $\begin{array}{l}\text { Individual (Farmer), Corporate } \\
\text { (Producer Organization, Company) }\end{array}$ & Individual (Farmer) \\
\hline $\begin{array}{l}\text { Total financing requirement } \\
\text { (USD) }\end{array}$ & $9,332,625$ & $1,190,372$ \\
\hline $\begin{array}{l}\text { Projected implementation period } \\
\text { (years) }\end{array}$ & 7 & 5 \\
\hline $\begin{array}{l}\text { Number of beneficiaries } \\
\text { (Individual or Business) }\end{array}$ & 875 & 875 \\
\hline $\begin{array}{l}\text { Period during which the solution } \\
\text { will reduce climate risk for each } \\
\text { beneficiary (years) }\end{array}$ & 6 & 6 \\
\hline $\begin{array}{l}\text { Anticipated yield increase/cost } \\
\text { decrease }\end{array}$ & $85 \%$ & $25 \%$ \\
\hline $\begin{array}{l}\text { Anticipated ideal financing } \\
\text { strategy }\end{array}$ & Public investment, PPP, grant, loan & $\begin{array}{l}\text { Multi-stakeholder, public } \\
\text { (training, input } \\
\text { compensatory support) }\end{array}$ \\
\hline
\end{tabular}

Source: adapted by report authors from KAPRA report findings

For Business Case (1) - Extension of new olive varieties -more financing is required for setting up production stations for high quality olive varieties that are resistant to drought and for providing support to growers than for Business Case (2) which only requires training, awareness activities and grafting on farms as the main implementation steps. The financing needs of 9,332,625 USD for Business Case (1) are proposed to be covered by public investments, PPPs, grants and loans. For Business Case (2) a multistakeholder approach is suggested which involves public support (training, input support, compensatory support). The anticipated yield increase/cost decrease through Business Case (1) is $85 \%$ and for Business Case (2) the yield increase/cost decrease is anticipated to be $25 \%$.

A summary table showing the estimated budget needed for the 20 business cases selected is presented in Table 3.9 below: 
Table 3.9: Estimation on financing requirement of 20 Business Cases

\begin{tabular}{|c|c|c|c|c|c|c|c|c|c|c|}
\hline $\begin{array}{c}\text { Case } \\
\text { No. }\end{array}$ & Business Case & Key product(s) affected & $\begin{array}{l}\text { Number of } \\
\text { Beneficiaries } \\
\text { (Individual } \\
\text { or Business) }\end{array}$ & $\begin{array}{l}\text { Projected } \\
\text { implementation } \\
\text { period (year) }\end{array}$ & $\begin{array}{l}\text { Period during } \\
\text { which the } \\
\text { solution will } \\
\text { reduce climate } \\
\text { risk for each } \\
\text { beneficiary } \\
\text { (year) }\end{array}$ & $\begin{array}{l}\text { Ratio of the } \\
\text { Solution to be } \\
\text { Implemented to } \\
\text { Total Capacity } \\
\text { in the KMRB } \\
\text { (\%) }\end{array}$ & $\begin{array}{l}\text { Total } \\
\text { financing } \\
\text { requirement } \\
\text { (USD) }\end{array}$ & $\begin{array}{l}\text { Anticipated } \\
\text { Yield } \\
\text { Increase / } \\
\text { Cost } \\
\text { Decrease }\end{array}$ & $\begin{array}{l}\text { Prioritization of } \\
\text { Expert Team }\end{array}$ & $\begin{array}{c}\text { Anticipated Ideal Financing } \\
\text { Strategy }\end{array}$ \\
\hline 1 & $\begin{array}{l}\text { Financial support for air- } \\
\text { conditioning systems in small } \\
\text { dairy cattle farms }\end{array}$ & Cow’s Milk & 1,426 & 3 & 1 & $10 \%$ & 2,731,915 & $7 \%$ & Priority & Co-financing model \\
\hline 2 & $\begin{array}{l}\text { Support for production of } \\
\text { xerophilous outdoor } \\
\text { ornamental plant varieties }\end{array}$ & Outdoor ornamental plants & & & & & & & Priority & \\
\hline 3 & $\begin{array}{l}\text { Waste management in olive oil } \\
\text { facilities and factories }\end{array}$ & Olive (for oil) & 52 & 5 & 1 & $100 \%$ & $1,300,000$ & $50 \%$ & Low priority & Co-financing model \\
\hline 4 & $\begin{array}{l}\text { Extension of new olive } \\
\text { varieties of high quality that } \\
\text { are resistant to drought and } \\
\text { suitable for machine } \\
\text { harvesting }\end{array}$ & Olive (for oil) & 875 & 7 & 6 & $5 \%$ & $9,332,625$ & $85 \%$ & High Priority & $\begin{array}{l}\text { Public investment, PPP, } \\
\text { grant, loan }\end{array}$ \\
\hline 5 & $\begin{array}{l}\text { Development of efficient } \\
\text { irrigation systems in the } \\
\text { KMRB }\end{array}$ & $\begin{array}{l}\text { Olive (for oil), tomato (for } \\
\text { industry), fig (dry), } \\
\text { outdoor ornamental plants, } \\
\text { fodder crops (for cow } \\
\text { milk) }\end{array}$ & 2,700 & 7 & 1 & & $1,554,864$ & $20 \%$ & High Priority & $\begin{array}{l}\text { Support for public } \\
\text { training, co-financing } \\
\text { model }\end{array}$ \\
\hline 6 & $\begin{array}{l}\text { Supporting investments in } \\
\text { infrastructure preventing the } \\
\text { loss of irrigation water (closed } \\
\text { system irrigation) }\end{array}$ & $\begin{array}{l}\text { Olive (for oil), fig (dried), } \\
\text { tomato (for industry), } \\
\text { outdoor ornamental plants }\end{array}$ & & & & & & & High Priority & \\
\hline 7 & $\begin{array}{l}\text { Events intended to raise } \\
\text { awareness on climate change } \\
\text { at a local and national scale }\end{array}$ & $\begin{array}{l}\text { Olive (for oil), fig (dried), } \\
\text { tomato (for industry), } \\
\text { outdoor ornamental plants, } \\
\text { cow’s milk }\end{array}$ & & & & & & & High Priority & \\
\hline 8 & $\begin{array}{l}\text { Implementation of herd } \\
\text { management programs in } \\
\text { medium-size dairy cattle } \\
\text { businesses }\end{array}$ & Cow’s Milk & 100 & 1 & 1 & & $1,425,000$ & $20 \%$ & Low priority & Co-financing model \\
\hline 9 & $\begin{array}{l}\text { Promoting the use of different } \\
\text { materials rather than soil in the } \\
\text { production phase of outdoor } \\
\text { ornamental plants }\end{array}$ & Outdoor ornamental plants & & & & & & & Low priority & \\
\hline
\end{tabular}




\begin{tabular}{|c|c|c|c|c|c|c|c|c|c|c|}
\hline 10 & $\begin{array}{l}\text { Extended use of renewable } \\
\text { energy sources for product } \\
\text { processing }\end{array}$ & $\begin{array}{l}\text { Tomato (for industry), fig } \\
\text { (dried), olive (for oil) }\end{array}$ & 50 & 2 & 1 & & $4,000,000$ & $50 \%$ & Priority & Co-financing model \\
\hline 11 & $\begin{array}{l}\text { Replacing local olive varieties } \\
\text { that are vulnerable to climate } \\
\text { change in the region }\end{array}$ & Olive (for oil) & 875 & 5 & 6 & $5 \%$ & $1,190,372$ & $25 \%$ & High Priority & $\begin{array}{l}\text { Multi-stakeholder public } \\
\text { support (training, input } \\
\text { support, compensatory } \\
\text { support) }\end{array}$ \\
\hline 12 & Terracing of inclined groves & $\begin{array}{l}\text { Olive (for oil) and Fig } \\
\text { (dried) }\end{array}$ & 1000 & 7 & 3 & & $1,287,234$ & $15 \%$ & Priority & $\begin{array}{l}\text { Optional public support } \\
\text { (procurement of } \\
\text { services / direct public } \\
\text { implementation }\end{array}$ \\
\hline 13 & $\begin{array}{l}\text { Extension of efficient and } \\
\text { conscious use of fertilization } \\
\text { and plant protection (pesticide) } \\
\text { methods sensitive to the } \\
\text { environment and climate }\end{array}$ & $\begin{array}{l}\text { Olive (for oil), tomato (for } \\
\text { industry), fig (dry), } \\
\text { outdoor ornamental plants, } \\
\text { fodder crops (for cow } \\
\text { milk) }\end{array}$ & 1,600 & 2 & 5 & $6 \%$ & 72,000 & $10 \%$ & High Priority & $\begin{array}{l}\text { Optional public support } \\
\text { (procurement of } \\
\text { services / direct public } \\
\text { implementation }\end{array}$ \\
\hline 14 & $\begin{array}{l}\text { Collection of animal waste for } \\
\text { biogas production }\end{array}$ & Cow's Milk & 100 & 3 & 1 & & $3,319,149$ & $25 \%$ & Low priority & Co-financing model \\
\hline 15 & $\begin{array}{l}\text { Increasing the numbers of } \\
\text { manure pits in medium size } \\
\text { dairy cattle farms }\end{array}$ & Cow’s Milk & 500 & 5 & 1 & & $6,382,500$ & & Priority & Co-financing model \\
\hline 16 & $\begin{array}{l}\text { Afforestation aimed at } \\
\text { mitigating the effects of } \\
\text { carbon emission and the } \\
\text { intensification of efforts to } \\
\text { prevent erosion and floods }\end{array}$ & $\begin{array}{l}\text { Olive (for oil), fig (dried), } \\
\text { tomato (for industry), } \\
\text { outdoor ornamental plants }\end{array}$ & & & & & & & Priority & \\
\hline 17 & $\begin{array}{l}\text { Improvements in fig drying } \\
\text { systems }\end{array}$ & Fig (dried) & 5,000 & 1 & & $40 \%$ & 210,000 & & Low priority & Public input support \\
\hline 18 & $\begin{array}{l}\text { Improvements in the cold } \\
\text { chain for raw milk and the } \\
\text { utilization of renewable energy } \\
\text { sources in the cold chain }\end{array}$ & Cow’s Milk & 20 & 2 & 1 & $23 \%$ & $1,600,000$ & $50 \%$ & Priority & Co-financing model \\
\hline 19 & $\begin{array}{l}\text { Extension of practices } \\
\text { preventing evaporation in the } \\
\text { soil }\end{array}$ & $\begin{array}{l}\text { Tomato (for industry), } \\
\text { outdoor ornamental plants }\end{array}$ & 400 & 5 & 1 & $3 \%$ & 88,851 & $20 \%$ & High Priority & $\begin{array}{l}\text { Public training and input } \\
\text { support }\end{array}$ \\
\hline 20 & $\begin{array}{l}\text { Using domestic wastewater in } \\
\text { counties for agricultural } \\
\text { irrigation }\end{array}$ & $\begin{array}{l}\text { Olive (for oil), fig (dried), } \\
\text { tomato (for industry), } \\
\text { outdoor ornamental plants }\end{array}$ & & & & & & & Priority & \\
\hline
\end{tabular}

Source: Prepared in the KAPRA study. 


\section{Lifeline Utilities Risk Assessment and Business Continuity Planning (LUBCP)}

\subsection{Context of the Assessment}

The Lifeline Utilities Risk Assessment and Business Continuity Planning (LUBCP) study aims to carry out business continuity planning focusing on the lifeline utilities of Istanbul Tuzla Organized Industrial Zone (ITOIZ) to build resilience into the industry and to increase its business competitiveness. It provides understanding of risks for industries at ITOIZ due to failure of lifeline utilities, when they are affected by natural hazards. Istanbul is the economic center of the Turkey's economy, generating $30 \%$ of the country's GDP. Tuzla is one of the 40 districts of Istanbul which hosts 5 organized industrialized zones. Tuzla's importance as an industrial center is increasing; its location is attractive, hosting the largest shipyard area in Turkey and being close to major trade ports, an airport as

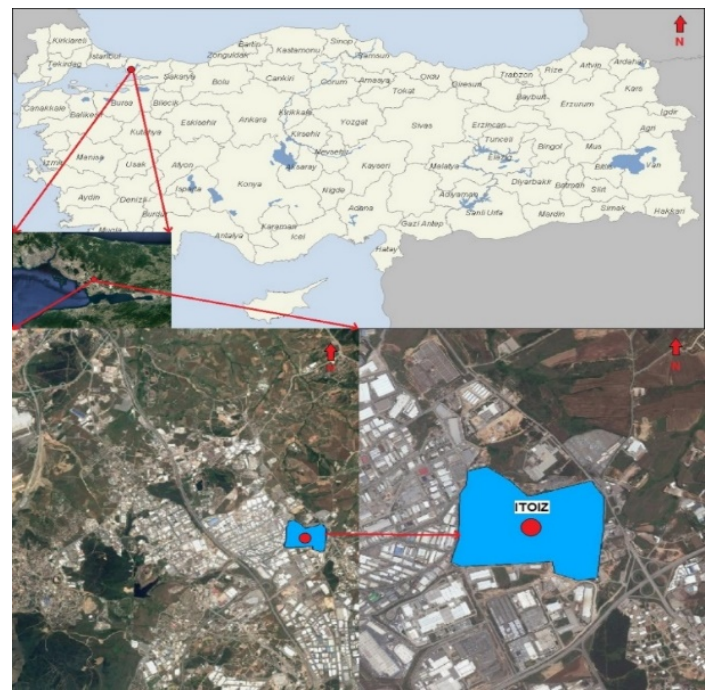
well as having good road accessibility.

The study was conducted with the Istanbul Chamber of Industry and the Tuzla Organized Industrialized Zone (ITOIZ) in Tuzla, Istanbul, which hosts approximately 100 companies of different types of industries, such as manufacturing, automotive, steel, electronic and pharmaceutical industries. The different industries are relying on different kinds of lifeline utilities and thus, ITOIZ is an interesting case study for conducting a risk assessment of lifeline utilities, given the fact that Istanbul and Tuzla are highly prone to natural hazards. The most dangerous natural disasters for Istanbul are earthquakes and landslides as well as floods, high winds and extreme temperatures.

\subsection{Steps and methodology of a lifeline utilities risk assessment}

The results of the study may be used for other industrial zones in Turkey, or elsewhere in the world, to conduct a risk assessment of lifeline utilities and to develop a BCP. To conduct LUBCP study, five-step procedure is developed which are presented below:

1. Analysis of lifeline utilities

2. Analysis of natural hazards

3. Susceptibility of lifeline utilities to natural hazards

4. Lifeline utilities risk assessment

5. Business Continuity Planning

The above steps have been identified in the LUBCP assessment based on an analysis of the international literature on Business Continuity Frameworks. The following sections will discuss each of the above steps, based on the methodology used in the LUBCP report. 


\subsubsection{Analysis of lifeline utilities}

In the LUBCP the analysis of lifeline utilities starts with a compilation of all lifeline utilities as well as the details of their operation and maintenance and the visualization of the lifeline utilities in the industrialized zone. The utilities were identified for the ITOIZ are waste water, process water storm sewer, roads, electricity, natural gas, communication utilities and firefighting.

All lifeline utilities, except for telecommunications and natural gas, are operated by ITOIZ itself. Table 4.1 gives an example from the LUBCP of a more detailed analysis for the electricity utilities at Tuzla Industrialized Zone. In summary, ITOIZ is the electricity operator for its industries, providing cheaper electricity than the market. ITOIZ also operates and maintains the electricity line to the transformer center which allows for quick application of power increases, if needed, and to provide a backup line in case of power failures.

\section{Table 4.1: Analysis of Electricity Utilities at ITOIZ}

\begin{tabular}{|c|c|c|}
\hline Stakeholders & Operation & Maintenance \\
\hline $\begin{array}{l}\text { ITOIZ } \\
\text { Management }\end{array}$ & $\begin{array}{l}\text { - In case of a disruption it is estimated to cost } 10 \text { to } \\
15 \text { minutes of down-time to restore the power by } \\
\text { using the high voltage ring in the other direction. } \\
\text { - ITOIZ management is in charge of this process. } \\
\text { ITOIZ is also responsible for the operation of the } \\
\text { main line to the TEIAS transformer centre. }\end{array}$ & $\begin{array}{l}\text { - Transformers are maintained two times } \\
\text { annually. Electricity lines (all } \\
\text { underground) do not go under any } \\
\text { periodic check or maintenance. } \\
\text { - ITOIZ is also responsible for the } \\
\text { maintenance of the main line to the } \\
\text { TEIAS transformer centre. }\end{array}$ \\
\hline $\begin{array}{l}\text { Maintenance } \\
\text { Contractor }\end{array}$ & NA & $\begin{array}{l}\text { The repair activity of the internal electricity } \\
\text { grid is being done by the main } \\
\text { subcontractor located within ITOIZ. }\end{array}$ \\
\hline Industries & $\begin{array}{l}\text { The low voltage from the transformers to each } \\
\text { industrial site is by individual power lines that are } \\
\text { under responsibility of the sites. On this lowest } \\
\text { level no redundancy is present. }\end{array}$ & NA \\
\hline
\end{tabular}

Source: Prepared in the LUBCP study.

Figure 4.1 shows a combined map of all lifeline utilities in the ITOIZ. As shown below, all utilities are very close to each other.

Figure 4.1: Map with all lifeline utilities at ITOIZ

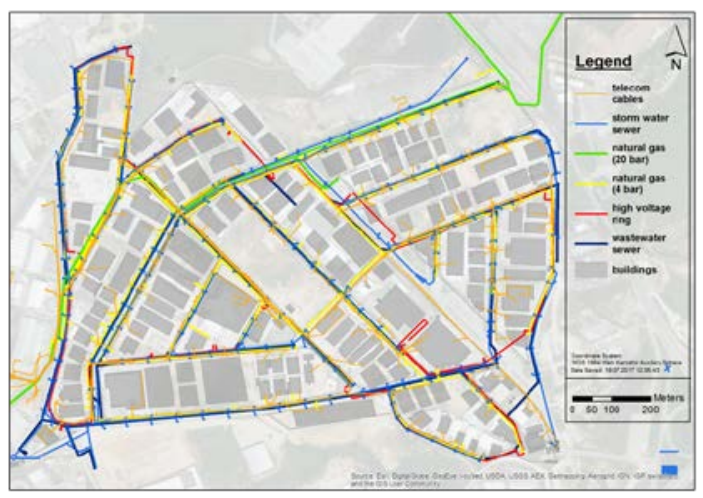

Source: Prepared in the LUBCP study. 
Next, the interdependencies between lifeline utilities and potential cascading effects have also been analyzed as part of the lifeline utilities assessment in the LUBCP. In order to do so, a stakeholder workshop was conducted with participants from the ITOIZ management, industries located in the industrial zone and representatives from lifeline utilities companies.

The stakeholders had discussions on how the industries depend on the different lifeline utilities and the relations between the lifeline utilities. The methodology, which was used to visualize the discussions, is the Circle tool, which was developed by Deltares. Figure 4.2 shows the interdependencies between different lifeline utilities a well as the dependencies of different industries on the lifeline utilities at Tuzla Industrialized Zone.

Figure 4.2: Completed CIrcle tool

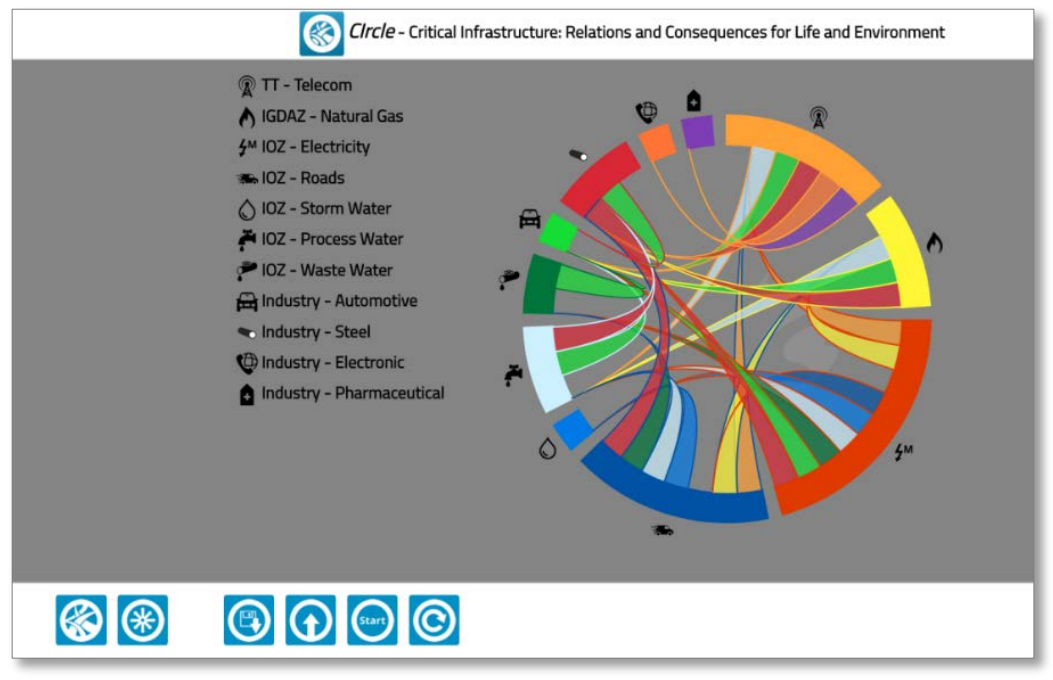

Source: Prepared in the LUBCP study.

Table 4.2 gives an example from the LUBCP assessment for the telecommunications network which is operated by Turk Telecom. It shows that gas as well as other lifeline utilities are dependent on the telecommunications network. Also, many industries, the automotive, steel, electronic and pharmaceutical industries, are dependent on the telecommunications utility for their just-in-time deliveries as well as procurement etc. The automotive and pharmaceutical industries would experience the most significant impacts of an interruption.

Table 4.2 Analysis for telecommunications utility

\begin{tabular}{|l|l|l||}
\hline \hline LU & Description of Relationship & Significance \\
\hline Gas & $\begin{array}{l}\text { In case of calamities and LU interruptions, response teams are highly dependent on ICT to } \\
\text { coordinate their repair activities. IGDAS has satellite phones for their emergency teams. }\end{array}$ & Moderate \\
\hline other LUs & $\begin{array}{l}\text { In case of LU interruptions, response teams are dependent on ICT to initiate and } \\
\text { coordinate repair activities. If staff of the repair teams cannot be reached, this might } \\
\text { significantly increase the duration of the LU interruption, such as power outage. }\end{array}$ & Significant \\
\hline Industry & Description of Dependencies & Significance \\
\hline
\end{tabular}




\begin{tabular}{|l|l|l||}
\hline \hline Automotive & $\begin{array}{l}\text { Several industries in Tuzla IOS provide just-in-time delivery of products to the } \\
\text { automotive sector. This strongly relies on stable ICT service as all systems are run online. }\end{array}$ & Significant \\
\hline Steel & $\begin{array}{l}\text { Supply networks are entirely digital - orders, procurement, e-invoice, everything happens } \\
\text { based on ICT. An interruption would have impacts to industries outside Tuzla OIZ, too. }\end{array}$ & Moderate \\
\hline Electronic & $\begin{array}{l}\text { Electronic companies have higher requirements for security precautions, which to a large } \\
\text { extent uses CCTV. This cannot be operated without ICT services. }\end{array}$ & Moderate \\
\hline Pharmaceutical & $\begin{array}{l}\text { In the pharmaceutical sector complex measurement systems for quality management are } \\
\text { in place, which will be impacted from ICT outages significantly. This might result in } \\
\text { discarding larger batches of the production, if the quality of the products cannot be } \\
\text { guaranteed. }\end{array}$ & Significant \\
\hline
\end{tabular}

Source: Prepared in the LUBCP study.

Some examples of possible cascading effects which mean that the outage of a LU can lead to the outage of another LU which in turn might impact on an industry are presented below:

- An outage of the electricity network will lead to an immediate outage of the ICT services, as modems and routers rely on electricity which may lead to disruption in the just-in-time supply chain in or out of the ITOIZ.

- Interruptions in the road network of ITOIZ may impact the supply of process water, which is required for production in various industries.

- Failure of the storm sewer system may lead to failure of the other utilities in the cross section of the street due to erosion.

\subsubsection{Analysis of natural hazards}

The analysis in the LUBCP covers the following hazards:

- Hail

- Snow

- Storm / high winds

- Extreme high temperatures

- Extreme low temperatures

- Floods (induced by heavy precipitation)

- Landslides (induced by precipitation)

- Sea level rise

- Earthquakes

- Landslides (earthquake induced)

Types of hazards that are expected to decrease or increase in the future in Istanbul are shown in Table 4.3 below. 
Table 4.3 Summary of current and future hazard levels in Istanbul

\begin{tabular}{|c|c|c|c|}
\hline \multirow[b]{2}{*}{ Climate Hazard } & \multicolumn{3}{|l|}{ Summary of hazard level in Istanbul } \\
\hline & Current & $\begin{array}{l}\text { Future } \\
2030\end{array}$ & $\begin{array}{l}\text { Future } \\
2050\end{array}$ \\
\hline $\begin{array}{l}\text { Heavy snow/ icy } \\
\text { conditions }\end{array}$ & $\begin{array}{l}\text { Increasing average temperatures might result in less snow fall and icy } \\
\text { conditions but will increase rain on the other hand. Minimum } \\
\text { temperatures will increase, resulting in less icy days. }\end{array}$ & & \\
\hline $\begin{array}{l}\text { Extreme precipitation } \\
\text { (rain fall) }\end{array}$ & $\begin{array}{l}\text { Due to an expected shift in the atmospheric circulation intense } \\
\text { precipitation events are likely to increase in and around Istanbul. }\end{array}$ & & \\
\hline Wind & $\begin{array}{l}\text { Stronger northern winds during the summer period can be observed from } \\
\text { historic trends and climate projections. However, no trend for the past } \\
\text { and future climate in extreme winds has been found. Wind is a hard to } \\
\text { predict parameter in the Istanbul area and awareness by analysing } \\
\text { climate predictions and forecasts is necessary. }\end{array}$ & & \\
\hline Hail & $\begin{array}{l}\text { Hardly any information is available about the number of hailstorms and } \\
\text { whether their intensity is increasing. A severe hailstorm may occur with } \\
\text { a return period of } 75 \text { years. }\end{array}$ & & \\
\hline $\begin{array}{l}\text { Extreme } \\
\text { temperatures (high) } \\
\text { and urban heat island } \\
\text { (UHI) effect }\end{array}$ & $\begin{array}{l}\text { A slight cooling of the area can be seen from climate studies. Despite the } \\
\text { slight decrease in heat waves in the Istanbul area, the UHI intensity } \\
\text { increased in the area around Tuzla while minimum temperatures } \\
\text { increased, and the city has grown. }\end{array}$ & & \\
\hline $\begin{array}{l}\text { Extreme } \\
\text { temperatures (low) }\end{array}$ & $\begin{array}{l}\text { Extreme low temperatures became more common in the North of the } \\
\text { city, the South (and especially the area around Tuzla), on the other hand, } \\
\text { experienced an increase of the minimum temperature and less extreme } \\
\text { low temperatures compared to the North. }\end{array}$ & & \\
\hline (Urban) floods & $\begin{array}{l}\text { An increase in surface run-off is likely as a consequence of the } \\
\text { intensification of rain storms, severe erosion, rise of summer } \\
\text { temperatures (and related longer dry periods). Floods are expected to } \\
\text { happen more often. }\end{array}$ & & \\
\hline $\begin{array}{l}\text { Landslides } \\
\text { (precipitation } \\
\text { induced) }\end{array}$ & $\begin{array}{l}\text { The sloping sites of the city are in general known for landslides. Higher } \\
\text { precipitation amounts can increase the moving speed of landslides or } \\
\text { induce mudflows. }\end{array}$ & & \\
\hline Sea level rise & An increase in sea level rise is virtually certain. & & \\
\hline
\end{tabular}

Source: Prepared in the LUBCP study.

In addition to climate induced hazards, the LUBCP carried out an assessment of the hazard of earthquakes. For this purpose, an Independent Geotechnical Site Investigation was conducted which is based on a satisfactory number and depth of boreholes throughout the premises of the ITOIZ. It was found that no soil amplification is expected in the case of an earthquake. In a next step, the buildings at ITOIZ were analyzed. All buildings at ITOIZ have been designed according to the current Earthquake Code in Turkey. ITOIZ is located in an earthquake risk zone 1 as per the previous hazard map of Turkey. In the LUBCP the earthquake risk is analyzed according to the DLH 2008 index. ${ }^{13}$ The results of the analysis for the ITOIZ show that there is a $50 \%$ probability that an earthquake of the seismic level D1 will occur within the next 50 years

${ }^{13}$ DLH 2008 index takes into account three seismic levels, i.e. D1 (return period of 72 years), D2 (return period of 475 years) and D3 (return period of 2475 years). D1 refers to a seismic level with the lowest intensity, but the highest probability of occurrence, whereas D3 has the highest intensity with the lowest probability of occurrence. Normal buildings are checked against the D1 and D2 levels, whereas D3 is only analysed for structures such as nuclear power plants, and thus, is not used in this report. 
and that there is a $10 \%$ probability that an earthquake of level D2 will happen over the course of this time period.

Table 4.4 provides a summary of the hazard scenarios which are relevant for the ITOIZ. The table shows hail, snow, floods (precipitation induced), landslides (precipitation induced), earthquakes D1, earthquakes D2 and landslides (earthquake induced). Storm/high wind speed, extreme high and low temperatures and sea level rise have also been analyzed, but they do not pose a particular threat to the lifeline utilities at ITOIZ and thus, have not been further analyzed in the risk assessment. Also, those hazard scenarios which are more frequent do not pose a high risk, and thus, have not been further considered in the analysis. Hazards which are less frequent pose higher risks, as they may cause higher failures. The LUBCP assessment also shows the regional scale of the hazard to the lifeline utility as well as the return period. For example, hail is perceived as a local hazard with a return period of 75 years.

Table 4.4 Hazard scenarios for Tuzla Industrialized Zone

\begin{tabular}{|l|l|l|l|}
\hline Hazard & $\begin{array}{l}\text { Scale of hazard } \\
\text { Is only ITOIZ affected or } \\
\text { also area around? }\end{array}$ & $\begin{array}{l}\text { Return period at which } \\
\text { first susceptibility of an } \\
\text { LU starts }\end{array}$ & Effects of climate change \\
\hline Hail & Local & 75 years & Unknown \\
\hline Snow & Large area & $5-20$ years* & Return period will increase \\
\hline Floods - after heavy precipitation & Local & 2 years & \multirow{2}{*}{$\begin{array}{l}\text { Return periods may decrease } \\
\text { and become almost half of } \\
\text { current return period }\end{array}$} \\
\cline { 1 - 2 } Landslides (precipitation induced) & Local & $50-200$ years* & \\
\hline Earthquake D1 (“small”) & Large area & 50 years & \\
\hline Earthquake D2 (“medium”) & Very large area & 475 years & 475 years \\
\cline { 1 - 2 } Landslides (earthquake induced) & Large area & \multicolumn{2}{|l}{} \\
\hline
\end{tabular}

Source: Prepared in the LUBCP study.

\subsubsection{Susceptibility of lifeline utilities to natural hazards}

After analyzing the lifeline utilities in an industrialized zone as well as the natural hazards which pose a risk to the zone, the susceptibility of the given lifeline utilities to the identified natural hazards needs to be studied in detail. The analysis has been based on inputs by management of the industrialized zone as well as expert judgement in the LUBCP.

Table 4.5 provides an example from the LUBCP of an overview table, showing which lifeline utilities are susceptible to which types of identified hazards. For each lifeline utility all relevant natural hazards have been analyzed in more detail, especially regarding the expected duration of failure of a lifeline utility due to a specific hazard, as well as the regional scale of the hazard, which is used to estimate the duration of failure of the lifeline utility. Also, the cascading effects have been taken into account in the susceptibility analysis. There are certain lifeline utilities which are not directly susceptible to natural hazards, but a cascading effect might lead to failure of this utility which is also considered as being susceptible to a given natural hazard in the LUBCP analysis. 
Table 4.5 Susceptibility of lifeline utilities at ITOIZ to identified natural hazards

\begin{tabular}{|l|c|c|c|c|c|c|}
\hline Lifeline utility & Snow & Hail & $\begin{array}{l}\text { Intense } \\
\text { rainfall and } \\
\text { floods }\end{array}$ & Earthquakes & $\begin{array}{l}\text { Landslide } \\
\text { (precipitation } \\
\text { induced) }\end{array}$ & $\begin{array}{l}\text { Landslide } \\
\text { (earthquake } \\
\text { induced) }\end{array}$ \\
\hline Natural gas & & & & $X$ & $X$ & X \\
\hline Electricity & & & $X$ & $X$ & $X$ & $X$ \\
\hline Road transport & $\mathrm{X}$ & & $\mathrm{X}$ & $\mathrm{X}$ & $\mathrm{X}$ & $\mathrm{X}$ \\
\hline Process water & $\mathrm{X}$ & $\mathrm{X}$ & $\mathrm{X}$ & $\mathrm{X}$ & $\mathrm{X}$ & $\mathrm{X}$ \\
\hline Waste water & $\mathrm{X}$ & & $\mathrm{X}$ & & $\mathrm{X}$ \\
\hline Drain water & $\mathrm{X}$ & & $\mathrm{X}$ & $\mathrm{X}$ & $\mathrm{X}$ \\
\hline Communication & & & $\mathrm{X}$ & $\mathrm{X}$ & $\mathrm{X}$ & $\mathrm{X}$ \\
\hline
\end{tabular}

Source: Prepared in the LUBCP study.

The susceptibility analysis will be further showcased on the basis of the example of the LUBCP, analyzing the susceptibility of the electricity supply to natural hazards. Table 4.5 shows that for the electricity utility susceptibility to rainfall and floods, earthquakes as well as landslides (precipitation and earthquake induced) has been identified. Intense rainfall and floods could cause short circuits at the transformer station, in case floods reach a depth of $30-50 \mathrm{~cm}$ above the ground. However, the return period is estimated to be only 50-200 years and it is expected that necessary repairs would only take $1-3$ days. Earthquakes could cause soil movements which might lead to failure of electricity cables. For earthquakes the return period is expected to be more than 475 years. Repairs of the electricity network are expected to take only 1 day for a D1 earthquake, however, more than one day for a heavier D2 earthquake. As landslides could be either precipitation induced, or earthquake induced the same return periods as for heavy precipitation/earthquakes are expected, i.e. 50-200 years for precipitation induced landslides and more than 475 years for an earthquake induced landslide. After failure of an electricity cable due to a landslide, it is expected that repairs would only take 1 day and likely a few more days if the landslide was induced by a heavier earthquake.

Table 4.6 and Table 4.7 provide a summary from the susceptibility analysis in the LUBCP, showing the estimated return period in years for each hazard scenario (Table 4.6) the estimated duration of an outage for all lifeline utilities for different types of hazards (Table 4.7). The highest duration of outage is expected for a D2 earthquake as well as an earthquake induced landslide for most of the lifeline utilities, which could range from a week to a month.

Table 4.6 Estimated return period (in years) for different hazard scenarios and lifeline utilities

\begin{tabular}{|l|l|l|l|l|l|l|l|}
\hline Lifeline utility & Snow & Hail & $\begin{array}{l}\text { Intense } \\
\text { rainfall and } \\
\text { floods }\end{array}$ & D1 earthquake & $\begin{array}{l}\text { D2 } \\
\text { earthquake }\end{array}$ & $\begin{array}{l}\text { Landslide } \\
\text { (precipitation } \\
\text { induced) }\end{array}$ & $\begin{array}{l}\text { Landslide } \\
\text { (earthquake } \\
\text { induced) }\end{array}$ \\
\hline Natural gas & - & - & - & $>475$ & $>475$ & $50-200$ & $>475$ \\
\hline Electricity & - & - & $50-200$ & $>475$ & $>475$ & $50-200$ & $>475$ \\
\hline Road transport & $5-20$ & - & $20-50$ & 50 & 475 & $50-200$ & $>475$ \\
\hline Process water & $20-50$ & $>200$ & $20-50$ & 50 & 475 & $50-200$ & $>475$ \\
\hline Waste water & $>200$ & - & - & 50 & 475 & - & 50 \\
\hline Storm sewer & $20-50$ & - & $5-20$ & 50 & 475 & $50-200$ & $>475$ \\
\hline Communication & - & - & $50-200$ & $50-200$ & 475 & $50-200$ & $>475$ \\
\hline
\end{tabular}

Source: Prepared in the LUBCP study. 
Table 4.7 Duration of outage for different hazard scenarios and lifeline utilities

\begin{tabular}{|c|c|c|c|c|c|c|c|}
\hline $\begin{array}{l}\text { Lifeline } \\
\text { utility }\end{array}$ & Snow & Hail & $\begin{array}{l}\text { Intense } \\
\text { rainfall and } \\
\text { floods }\end{array}$ & D1 earthquake & D2 earthquake & $\begin{array}{l}\text { Landslide } \\
\text { (precipitation } \\
\text { induced) }\end{array}$ & $\begin{array}{l}\text { Landslide } \\
\text { (earthquake } \\
\text { induced) }\end{array}$ \\
\hline Natural gas & - & & - & 1-3 days & Week - month & 1-3 days & Week - month \\
\hline Electricity & - & & 1-3 days & $<1$ day & $1-3$ days & $<1$ day & 1-3 days \\
\hline $\begin{array}{l}\text { Road } \\
\text { transport }\end{array}$ & $\begin{array}{l}<1 \\
\text { day }\end{array}$ & & 1-3 days & $<1$ day & Week - month & 1-3 days & Week - month \\
\hline $\begin{array}{l}\text { Process } \\
\text { water }\end{array}$ & $\begin{array}{l}1-3 \\
\text { days }\end{array}$ & $<1$ day & 1-3 days & 1-3 days & Week - month & 1-3 days & Week - month \\
\hline Waste water & $\begin{array}{l}\text { 3 days } \\
\text { - week }\end{array}$ & & - & 1-3 days & Week - month & - & Week - month \\
\hline Drain water & $\begin{array}{l}1-3 \\
\text { days }\end{array}$ & & 1-3 days & 1-3 days & Week - month & 1-3 days & Week - month \\
\hline $\begin{array}{l}\text { Communi- } \\
\text { cation }\end{array}$ & - & & 1-3 days & 1-3 days & Week - month & 1-3 days & Week - month \\
\hline
\end{tabular}

Source: Prepared in the LUBCP study.

\subsubsection{Lifeline utilities risk assessment}

\subsubsection{Methodology for the risk assessment}

The following data is used for the risk assessment in the LUBCP study:

- Likelihood of failure of lifeline utilities resulting from a natural hazard and,

- Consequence of failure of lifeline utilities resulting from a natural hazard.

The following paragraphs provide more information on the required data mentioned above. First, the likelihood of failure of the lifeline utilities due to a natural hazard needs to be determined. This information is based on the estimated return period (in years) for the different hazards for each of the lifeline utilities, which has been estimated in a previous step in the LUBCP assessment (see Table 4.6 above). Next, the return periods have been transferred to a scale in the LUBCP assessment. Table 4.8 shows the likelihood levels that have been assigned to the different categories of return periods. The table has been developed in the LUBCP report based on other risk assessments and has been evaluated by a stakeholder workshop with different participating industries.

Table 4.8 Likelihood level classes in the LUBCP assessment

\begin{tabular}{|ll|}
\hline \hline Likelihood level & Description \\
5 (very high) & Return period less than 5 years \\
4 (high) & $5-20$ years \\
3 (medium) & $20-50$ years \\
2 (low) & $50-200$ years \\
1 (very low) & Return period more than 200 years \\
\hline
\end{tabular}

Source: Prepared in the LUBCP study.

In a next step the consequences of failure of the lifeline utilities due to a natural hazard have been quantified in the LUBCP assessment which will inform decision makers whether or not maintenance or replacement activities need to take place. Based on a literature research, the quantification of five categories of impact are based on the following criteria: (i) safety; (ii) business continuity cost; (iii) repair cost; (iv) environmental impact and (v) reputation loss. Table 4.9 shows the categories of impact which have been developed for use in the LUBCP risk assessment. 
Table 4.9 Categories of Impact in the LUBCP assessment

\begin{tabular}{|c|c|c|c|c|c|}
\hline $\begin{array}{l}\text { Impact } \\
\text { level }\end{array}$ & Safety & Business continuity cost & Repair cost & Environmental impact & Reputation loss \\
\hline $\begin{array}{c}5 \\
\text { (very high) }\end{array}$ & $\begin{array}{l}\text { Several } \\
\text { casualties }\end{array}$ & $\begin{array}{l}\text { Businesses are going } \\
\text { bankrupt, ITOIZ } \\
\text { management unable to } \\
\text { continue managing } \\
\text { ITOIZ }\end{array}$ & $\begin{array}{l}\text { Inability to pay for } \\
\text { extremely high } \\
\text { repair cost }\end{array}$ & $\begin{array}{l}\text { Severe impact on the } \\
\text { environment outside } \\
\text { ITOIZ }\end{array}$ & $\begin{array}{l}\text { Severe loss of reputation, } \\
\text { businesses consider } \\
\text { moving out of ITOIZ }\end{array}$ \\
\hline $\begin{array}{c}4 \\
\text { (high) }\end{array}$ & Casualty & $\begin{array}{l}\text { Significant loss of } \\
\text { productivity }\end{array}$ & $\begin{array}{l}\text { Repair cost exceed } \\
\text { reserves of ITOIZ } \\
\text { management }\end{array}$ & $\begin{array}{l}\text { Significant impact on } \\
\text { the environment outside } \\
\text { ITOIZ }\end{array}$ & $\begin{array}{l}\text { Significant loss of } \\
\text { reputation, position of } \\
\text { ITOIZ management at } \\
\text { stake }\end{array}$ \\
\hline $\begin{array}{c}3 \\
\text { (fairly } \\
\text { high) }\end{array}$ & $\begin{array}{l}\text { Heavy } \\
\text { injuries }\end{array}$ & $\begin{array}{l}\text { Moderate loss of } \\
\text { productivity }\end{array}$ & $\begin{array}{l}\text { Repair cost exceed } \\
\text { yearly budget }\end{array}$ & $\begin{array}{l}\text { Moderate impact on the } \\
\text { environment within } \\
\text { ITOIZ }\end{array}$ & $\begin{array}{l}\text { Moderate loss of } \\
\text { reputation, notices on } \\
\text { media and complaints from } \\
\text { industries from outside } \\
\text { ITOIZ }\end{array}$ \\
\hline $\begin{array}{c}2 \\
\text { (medium) }\end{array}$ & $\begin{array}{l}\text { Minor } \\
\text { injuries }\end{array}$ & $\begin{array}{l}\text { Diversion of } \\
\text { management from } \\
\text { productive tasks }\end{array}$ & $\begin{array}{l}\text { Part of expected } \\
\text { exceptional } \\
\text { maintenance and } \\
\text { repair operations }\end{array}$ & $\begin{array}{l}\text { Slight impact on the } \\
\text { nearby surroundings } \\
\text { within ITOIZ }\end{array}$ & $\begin{array}{l}\text { Slight loss of reputation, } \\
\text { complaints of industries } \\
\text { from within ITOIZ }\end{array}$ \\
\hline 1 (low) & $\begin{array}{l}\text { Only } \\
\text { material } \\
\text { damage }\end{array}$ & Negligible & $\begin{array}{l}\text { Part of routine } \\
\text { maintenance }\end{array}$ & $\begin{array}{l}\text { Negligible impact on the } \\
\text { nearby surroundings of } \\
\text { the affected lifeline } \\
\text { utilities within ITOIZ }\end{array}$ & Negligible reputation loss \\
\hline
\end{tabular}

Source: Prepared in the LUBCP study.

For the risk assessment, different industries at ITOIZ were asked to rate the consequence of failure of the different lifeline utilities for different durations of the failure, based on the classification which has been developed in Table 4.9. The assessment did not distinguish according to different types of hazard, but solely according to the possible duration of the failure of the lifeline utilities. Thus, it shows the criticality of each of the lifeline utilities. Table 4.10 summarizes the results of the consequence rating. In the column named "Impact" the scores are averaged across the different industries. In the last column the standard deviation is calculated, which provides an indication for agreement (green) or disagreement (red) between the different industries.

Table 4.10 Scoring for impact of failure of lifeline utilities by different industries in ITOIZ

\begin{tabular}{|c|c|c|c|c|c|c|c|c|}
\hline Lifeline Utility & Duration & 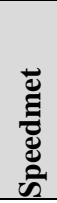 & 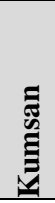 & 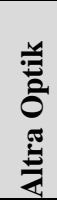 & 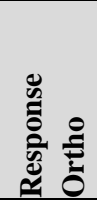 & \& $\frac{\mathfrak{\Xi}}{\tilde{\pi}}$ & $\begin{array}{l}\stackrel{\overrightarrow{\mathrm{Z}}}{\mathrm{Z}} \\
\stackrel{\mathrm{E}}{\mathrm{E}}\end{array}$ & 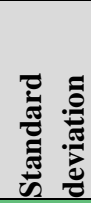 \\
\hline \multirow[t]{5}{*}{ Natural gas } & Less than one day & 1 & 1 & 1 & 1 & 1 & 1 & 0,0 \\
\hline & 1 day -3 days & 2 & 3 & 1 & 1 & 1 & 1,6 & 0,9 \\
\hline & 3 days - 1 week & 4 & 4 & 1 & 2 & 2 & 2,6 & 1,3 \\
\hline & Week - month & 4 & 5 & 1 & 2 & 2 & 2,8 & 1,6 \\
\hline & More than a month & 4 & 5 & 2 & 2 & 2 & 3 & 1,4 \\
\hline \multirow[t]{4}{*}{ Electricity } & Less than one day & 4 & 1 & 1 & 2 & 1 & 1,8 & 1,3 \\
\hline & 1 day -3 days & 5 & 3 & 2 & 3 & 2 & 3 & 1,2 \\
\hline & 3 days -1 week & 5 & 4 & 3 & 4 & 3 & 3,8 & 0,8 \\
\hline & Week - month & 5 & 5 & 4 & 5 & 4 & 4,6 & 0,5 \\
\hline
\end{tabular}




\begin{tabular}{|c|c|c|c|c|c|c|c|c|}
\hline & More than a month & 5 & 5 & 5 & 5 & 4 & 4,8 & 0,4 \\
\hline \multirow[t]{5}{*}{ Road transport } & Less than one day & 4 & 1 & 1 & 1 & 2 & 1,8 & $\overline{1,3}$ \\
\hline & 1 day -3 days & 5 & 3 & 1 & 2 & 2 & 2,6 & 1,5 \\
\hline & 3 days -1 week & 5 & 4 & 2 & 3 & 3 & 3,4 & 1,1 \\
\hline & Week - month & 5 & 5 & 3 & 5 & 3 & 4,2 & 1,1 \\
\hline & More than a month & 5 & 5 & 4 & 5 & 3 & 4,4 & 0,9 \\
\hline \multirow[t]{5}{*}{ Process water } & Less than one day & 1 & 1 & 1 & 1 & 1 & 1 & $\overline{0,0}$ \\
\hline & 1 day -3 days & 2 & 1 & 2 & 2 & 2 & 1,8 & 0,4 \\
\hline & 3 days -1 week & 3 & 1 & 3 & 3 & 3 & 2,6 & 0,9 \\
\hline & Week - month & 4 & 1 & 4 & 4 & 4 & 3,4 & 1,3 \\
\hline & More than a month & 5 & 1 & 5 & 5 & 4 & 4 & 1,7 \\
\hline \multirow[t]{5}{*}{ Waste water } & Less than one day & 1 & 1 & 1 & 1 & 1 & 1 & $\overline{0,0}$ \\
\hline & 1 day -3 days & 1 & 1 & 1 & 2 & 1 & 1,2 & 0,4 \\
\hline & 3 days -1 week & 2 & 2 & 1 & 3 & 1 & 1,8 & 0,8 \\
\hline & Week - month & 2 & 2 & 1 & 4 & 2 & 2,2 & 1,1 \\
\hline & More than a month & 3 & 3 & 1 & 4 & 2 & 2,6 & 1,1 \\
\hline \multirow[t]{5}{*}{ Drain water } & Less than one day & 1 & 1 & 1 & 2 & 2 & 1,4 & $\overline{0,5}$ \\
\hline & 1 day -3 days & 1 & 1 & 1 & 5 & 2 & 2 & 1,7 \\
\hline & 3 days -1 week & 2 & 2 & 1 & 5 & 3 & 2,6 & 1,5 \\
\hline & Week - month & 2 & 2 & 1 & 5 & 3 & 2,6 & 1,5 \\
\hline & More than a month & 3 & 3 & 1 & 5 & 3 & 3 & 1,4 \\
\hline \multirow[t]{5}{*}{ Communication } & Less than one day & 4 & 1 & 1 & 2 & 1 & 1,8 & 1,3 \\
\hline & 1 day -3 days & 5 & 2 & 2 & 4 & 3 & 3,2 & 1,3 \\
\hline & 3 days -1 week & 5 & 3 & 3 & 5 & 3 & 3,8 & 1,1 \\
\hline & Week - month & 5 & 4 & 4 & 5 & 4 & 4,4 & 0,5 \\
\hline & More than a month & 5 & 5 & 5 & 5 & 4 & 4,8 & 0,4 \\
\hline
\end{tabular}

Source: Prepared in the LUBCP study.

The results of the analysis show that electricity and communication are the most important lifeline utilities for the industries at ITOIZ as the consequences are perceived as the worst when these utilities are failing. While even less than one day duration of outage is not tolerable by industries, this failure may affect groundwater evacuation pumps in the basements of the industries' leading to flooding as well as outage of communication systems when modems cannot be used anymore. Also, process water and road transport seem to be very important lifeline utilities. In general, there is no lifeline utility at ITOIZ which seems to be of low importance. For each utility at least one industry has rated an outage of more than a week with an importance of 4 , which is already a very high rating. It is hard to determine a maximum duration of outage which is still tolerable for each lifeline utility, because this highly depends on the type of industry. If a Recovery Time Objective is to be set, a maximum failure of one day could be tolerated.

\subsubsection{Risk evaluation}

For the risk evaluation, the likelihood and the consequences of the event have been analyzed. The likelihood of the risk is physically determined, the consequences, however, can be determined based on a several different criteria, as explained above. For the risk evaluation in the LUBCP, risk matrices have been drafted. Figure 4.3 shows a risk matrix for all lifeline utilities in the ITOIZ which are affected by natural hazards. The type of natural hazard is not shown in this graph as the graph would not be readable anymore. The risk matrix uses different colors for showing risks that are unacceptable (red) - the likelihood is high and/or the consequences are very high, acceptable (green) - the likelihood is low and/or the consequences are low as 
well as in between these two categories (yellow) - where it still needs to be determined in the Business Continuity Plan whether the risks are acceptable and which efforts are required to reduce these risks.

Figure 4.3 Risk matrix for lifeline utilities at ITOIZ

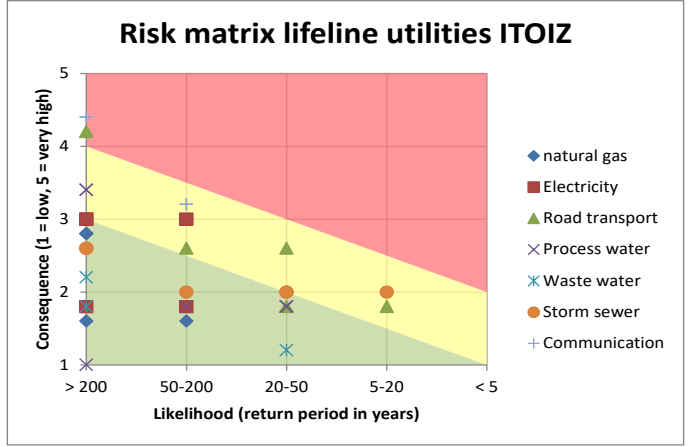

Source: Prepared in the LUBCP study.

A risk evaluation has also been carried out in the LUBCP for each type of lifeline utility, showing each type of hazard. The matrices are further showcased based on the example of the electricity sector and the road transport sector (Figure 4.4).

Figure 4.4 Risk matrix for the electricity, communication and storm sewer utilities at ITOIZ
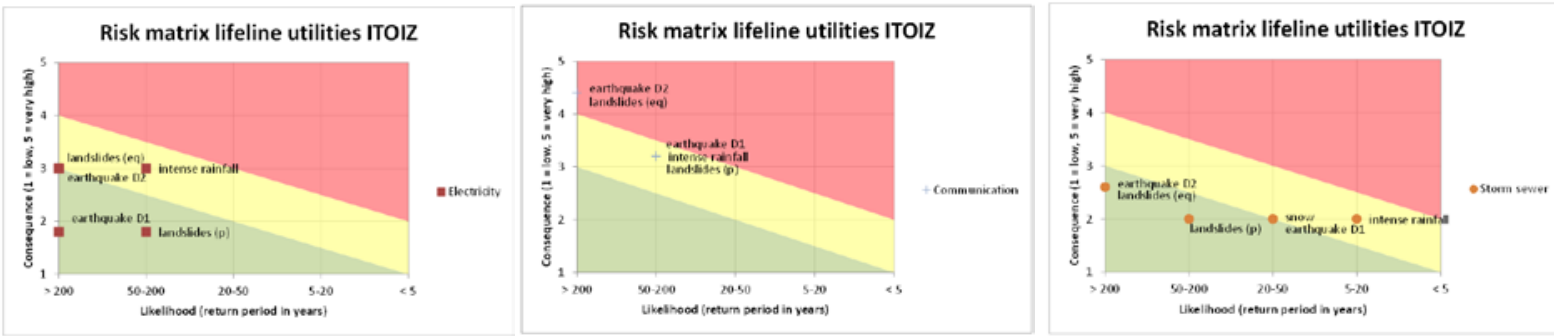

Source: Prepared in the LUBCP study.

When looking at the summary risk matrix for ITOIZ as well as the three matrices for the electricity, communication and storm sewer utilities, it can be seen that there are no risks with a high likelihood and a high consequence at ITOIZ, which shows a natural strength of the industrialized zone. There are, however, risks with a very low likelihood and high consequences. For example, this is the case for a heavy earthquake (D2) or an earthquake induced landslide for the communication utilities. There are other risks which will occur with a very low likelihood and moderate consequences due to a major earthquake. This is the case for the electricity utilities. The consequences of a major earthquake are lower for the electricity utilities than for the communication utilities because the expected duration of the failure is lower. There are also risks with high consequences ( 3 or higher) and a medium likelihood, e.g. intense rainfall effecting the electricity and the communication utilities. Also, Figure 4.4 shows that there exist certain risks with medium consequences and a high likelihood, which means that they will occur relatively often, e.g. intense rain affecting the storm sewer system. 
In addition, in the LUBCP different scenarios for the duration of the failure of the lifeline utility have been analyzed, as shown in Figure 4.5. For the analysis the estimated duration of failure for each lifeline utility has been either estimated to be one class lower (shorter duration) or one class higher (longer duration). The two matrices in Figure 4.5 show that there is high sensitivity of the risks to the duration of the outage of the lifeline utility. A longer duration of the outage results in a great increase of the risk and a shorter duration of the outage gives a much lower risk profile. This result is also highly important for the development of the Business Continuity Plan, which has the objective of reaching an acceptable level of risk. The risk evaluation shows that a reduction in the time of the outage can have a significant impact on the level of risk.

Figure 4.5 Risk matrix for different duration of failure of lifeline utilities at ITOIZ

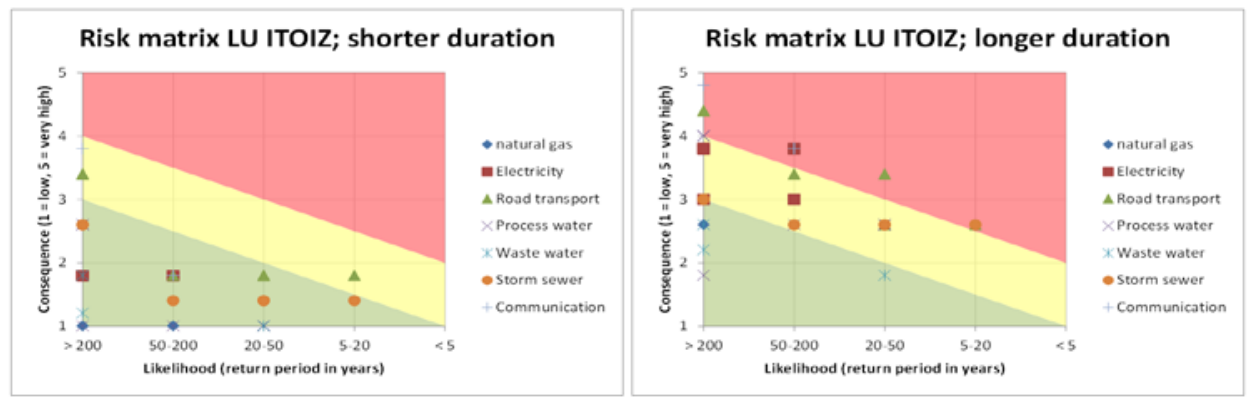

Source: Prepared in the LUBCP study.

The LUBCP took the analysis one step further and also took the effects of climate change into account in the risk evaluation. As shown in Table 4.3 above, it is expected that precipitation intensity and frequency might increase and that there will be less snowfall and icy conditions. Thus, in the analysis for precipitation and precipitation induced events (landslides), a higher return period is expected which means that they are more likely to happen. On the contrary, for snow the likelihood class has been shifted one class lower. Figure 4.7 shows the risk matrices for the electricity, communication and storm sewer utilities when taking into account climate change. When comparing Figure 4.5 to the matrices of Figure 4.6 it is clear that intense rainfall and precipitation induced landslides are leading to a higher risk profile for the electricity, communication and storm sewer utilities, resulting from flooding and landslides.

Figure 4.6 Risk matrix for certain lifeline utilities at ITOIZ, including climate change

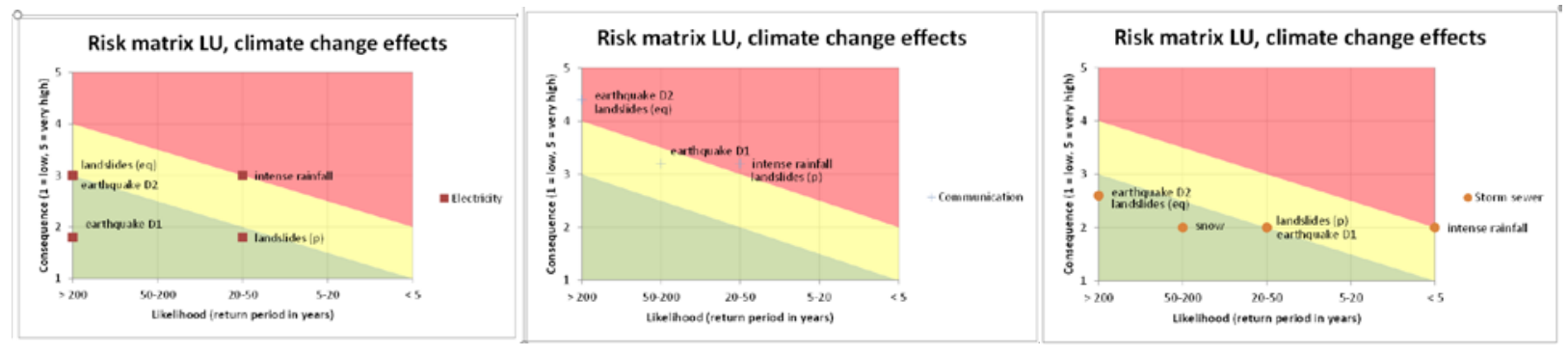

Source: Prepared in the LUBCP study. 


\subsubsection{Business Continuity Planning}

The final objective of the LUBCP has been the development of a Business Continuity Plan (BCP). The risk assessment that has been carried out is the main input into the Business Continuity Plan for ITOIZ. To make the ITOIZ more resilient, the main risks which have been identified in the risk assessment are being addressed in the BCP which includes possible actions to be taken during and after emergency situations as well as to get prepared before an emergency. The following paragraphs provide an overview of the framework for Business Continuity Planning and show the example of a BCP for the ITOIZ.

\subsubsection{Business Continuity Framework}

Business Continuity Planning is a risk-based approach, which means that only unacceptable risks are taken into account in a Business Continuity Plan (BCP). It is a document that guides organizations in times of an emergency and also contains organizational aspects. A BCP aims at addressing measures that can be done before, during and after an emergency. The LUBCP assessment uses the following definition of a Business Continuity Plan for the ITOIZ as "Business Continuity Planning is a process used to develop a practical plan for how ITOIZ management can recover or partially restore service of lifeline utilities to an acceptable level of operation within a pre-determined timeframe after an emergency situation. The resulting document is called a BCP."

A risk assessment is the basis of a Business Continuity Plan. The risk assessment methodology has been showcased above on the basis of the example of the ITOIZ. In the business continuity framework, the most important criteria for the classification of risk are: (i) duration of the failure; (ii) rate of operation of the lifeline utility (hours of availability of the utility); (iii) scale of the area for which the BCP is developed (in this report the example of Tuzla industrialized zone); and the (iv) scale of the hazard. Figure 4.7 shows a summary of the objectives of a business continuity plan and the importance of the rate of operation as well as the duration of the failure. The process of Business Continuity Planning does not stop with the development of a BCP, but implementation, monitoring and review are also essential steps for Business Continuity Management (BCM).

Figure 4.7 Objectives of a business continuity plan

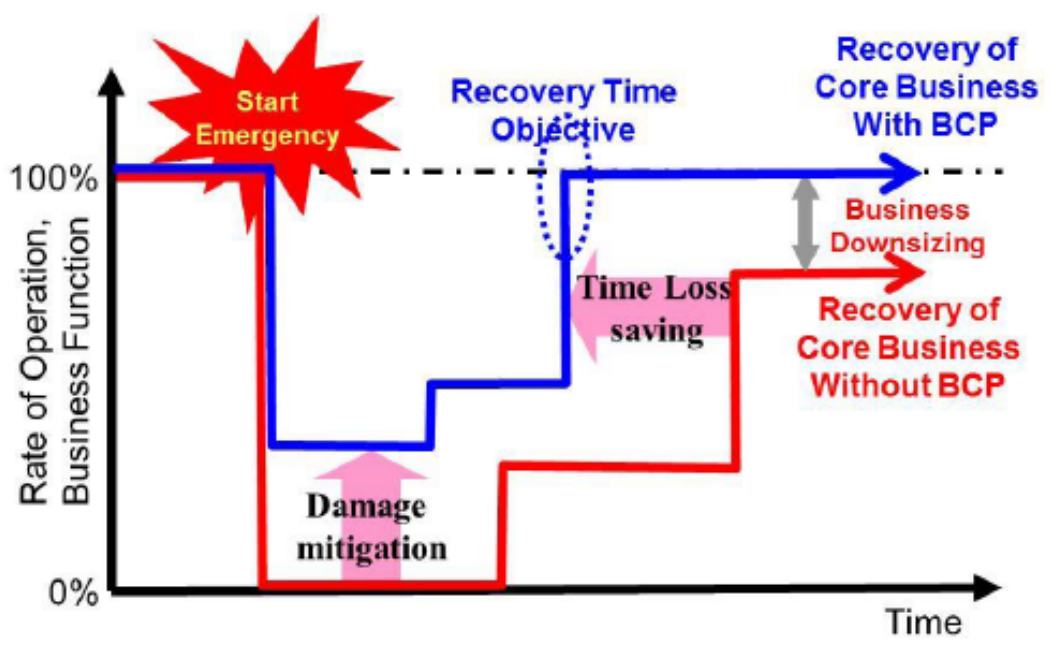

Source: Prepared in the LUBCP study. 


\subsubsection{Business Continuity Plan - Example of ITOIZ}

The Business Continuity Plan for the Tuzla Industrialized Zone is based on the results of the risk assessment, as explained above. Only the top risk scenarios have been addressed in the BCP for the Tuzla Industrialized Zone, i.e. those risk scenarios where the combination of likelihood and consequence is so high that the risk becomes unacceptable. Climate change has been taken into account for the determination of risk levels in the ITOIZ BCP. In the process of drafting the BCP, a few industries at ITOIZ have been asked about the acceptable duration of failure of each lifeline utility (RTO). The results have varied widely across the industries, but they have shown that a complete outage of lifeline utilities can only be accepted for a very short period of time and that the outage should be fixed within a few hours or within one day maximum. The duration of an outage of different lifeline utilities (as presented in Table 4.7 in this report) has been estimated to be much higher for certain scenarios. Thus, as a conclusion, the ITOIZ management needs to take measures for reducing the time of outage for each risk scenario and lifeline utility as much as possible in term of hours, to less than one day. A restored operation of the lifeline utility of $10 \%$ already makes the outage more acceptable in terms of days.

In this regard, an action plan has been prepared by the ITOIZ management which also includes a prioritization of the different lifeline utilities as various lifeline utilities could be affected at the same time by one or more hazards. Table 4.11 shows the prioritization table which also includes time objectives for the (emergency) repair of the lifeline utilities at ITOIZ, as well as the average acceptable duration of failure of the lifeline utilities (RTOs) which have been stated by the industries and the cascading effects.

Table 4.11 Prioritization of lifeline utilities in the BCP for ITOIZ

\begin{tabular}{|c|c|c|c|c|}
\hline \multicolumn{2}{|c|}{$\begin{array}{l}\text { Priority and time objective for } \\
\text { (emergency) repair }{ }^{\mathrm{a}}\end{array}$} & \multirow{2}{*}{$\begin{array}{l}\text { Lifeline utility } \\
\text { Roads }\end{array}$} & \multirow{2}{*}{$\begin{array}{l}\text { RTO for the } \\
\text { industries } \\
1 \text { day }\end{array}$} & \multirow{2}{*}{$\begin{array}{l}\text { Cascading effect } \\
\text { When roads fail on multiple locations it } \\
\text { may lead to unreachability of emergency } \\
\text { locations }\end{array}$} \\
\hline $1^{\mathrm{b}}$ & 3 hours & & & \\
\hline 2 & 8 hours & Electricity & 1 day & $\begin{array}{l}\text { Failure of ICT due to lack of power for } \\
\text { modems }\end{array}$ \\
\hline 3 & 8 hours & ICT & 8 hours & \\
\hline 4 & 16 hours & Process water & 16 hours & \\
\hline 5 & 1 day & Natural gas & 1 day & \\
\hline 6 & 1 day & Roads & 1 day & \\
\hline 7 & 2 days & Storm sewer & 2-3 weeks & $\begin{array}{l}\text { Failure of other LUs in the street due to } \\
\text { erosion (only during rainfall) }\end{array}$ \\
\hline 8 & 1 week & Waste Water & 3 months & \\
\hline
\end{tabular}

Another part of the BCP for ITOIZ concerns coordination and communication, which also involves the role and responsibilities of stakeholders during emergency situations. The BCP for ITOIZ also outlines concrete measures which should be taken before, during and after an emergency. These measures are based on best practices and lessons learned from other BCPs. Table 4.12 gives an overview of the measures that are planned to be carried out on a regular basis - both precautionary actions and preparedness actions. 
Table 4.12 Precautionary and Preparedness Actions in the BCP for ITOIZ

\begin{tabular}{|c|c|c|c|}
\hline No & Precautionary actions & Time target & Resources \\
\hline 1 & $\begin{array}{l}\text { Monitor the weather forecast for extreme precipitation, } \\
\text { thunderstorms and snow }\end{array}$ & Daily & Staff \\
\hline 2 & Inspect watercourses regularly & Each spring & Staff \\
\hline 3 & Clean watercourses regularly & Monthly & Staff \\
\hline 4 & $\begin{array}{l}\text { Remove or prevent rubbish on the roads to prevent blocking of } \\
\text { manholes }\end{array}$ & Monthly & Staff \\
\hline 5 & $\begin{array}{l}\text { Train staff for the emergency planning (see section in the BCP on } \\
\text { drills) }\end{array}$ & Yearly & Staff \\
\hline 6 & $\begin{array}{l}\text { Have sand and salt in stock to be able to use on the roads in case of } \\
\text { snow and ice }\end{array}$ & Before the event & Staff, sand and salt \\
\hline 7 & $\begin{array}{l}\text { Have gravels in stock to use during a possible erosion of the roads } \\
\text { due to heavy rain }\end{array}$ & Before the event & Staff, gravels \\
\hline 8 & $\begin{array}{l}\text { Repair uneven road sections before the winter season to ensure that } \\
\text { the road can be cleaned evenly and to reduce erosion by rain }\end{array}$ & Each autumn & $\begin{array}{l}\text { Staff, tiles, sand, } \\
\text { compactor }\end{array}$ \\
\hline No & Preparedness actions & Time target & Resources \\
\hline 1 & $\begin{array}{l}\text { When extreme weather is expected: warn industries and contractor to } \\
\text { be prepared }\end{array}$ & Before the event & Staff \\
\hline 2 & $\begin{array}{l}\text { When snow or ice is expected: mobilize contractor and use sand and } \\
\text { salt to reduce the chance of icing }\end{array}$ & Before the event & Staff \\
\hline 3 & $\begin{array}{l}\text { When extreme precipitation or thunderstorms are expected: remove } \\
\text { rubbish on the roads to ensure a proper run-off }\end{array}$ & Before the event & Staff \\
\hline 4 & $\begin{array}{l}\text { Maintain maximum water capacity at the water depots before an } \\
\text { extreme rain or snow event }\end{array}$ & Before the event & Staff \\
\hline
\end{tabular}

Source: Prepared in the LUBCP study.

Also, a step-by-step approach for measures during and after an emergency has been developed in the BCP for ITOIZ. Figure 4.8 shows the four steps which should be followed during an emergency at ITOIZ to ensure a smooth process: (i) identifying the hazard; (ii) prioritizing lifeline utilities; (iii) identifying actions; and (iv) implementing actions.

Figure 4.8 Step-by-step plan for ITOIZ

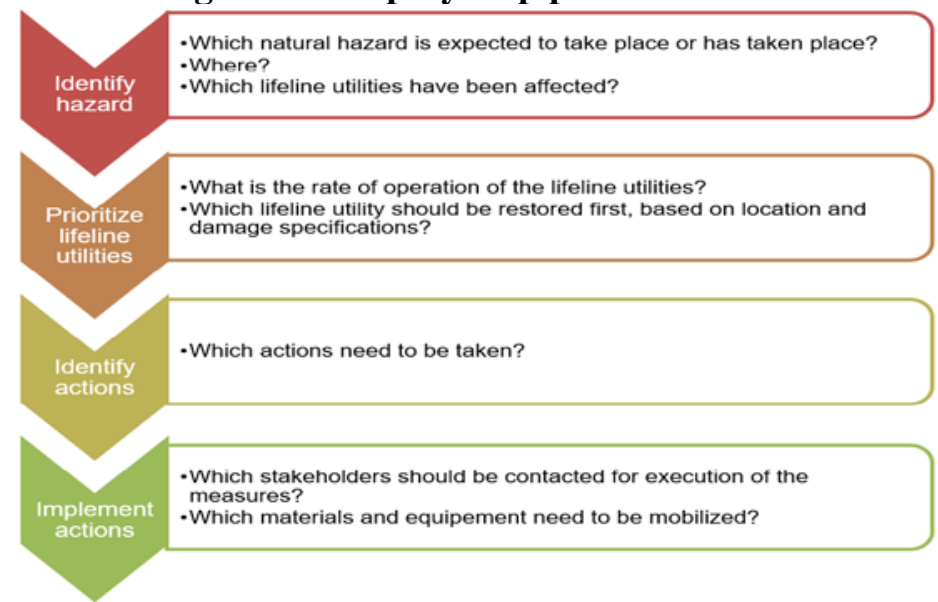

Source: Prepared in LUBCP study. 
Based on Table 4.11 above, a tool has been developed which helps to prioritize measures for the lifeline utilities in case of an emergency (Table 4.13 below). The prioritization tool is informed by the criticality and susceptibility analysis of the lifeline utilities (on industry basis). The tool is based on cascading effects and time objectives for the emergency repair of lifeline utilities. The industries have been asked to state the average acceptable failure of lifeline utilities (RTO) (dependent on the consequence of failure of a lifeline utility), which shows the criticality of each lifeline utility.

Table 4.13 Prioritization tool for lifeline utilities

\begin{tabular}{|c|c|c|c|c|c|c|}
\hline \multirow[t]{2}{*}{ Lifeline utility } & \multirow[t]{2}{*}{ Assets } & \multirow{2}{*}{\multicolumn{2}{|c|}{$\begin{array}{l}\text { Priority } \\
\text { and time } \\
\text { objective }\end{array}$}} & $\begin{array}{l}\text { Completely } \\
\text { damaged }\end{array}$ & $\begin{array}{l}\text { Partly } \\
\text { available }\end{array}$ & $\begin{array}{l}\text { Endangered } \\
\text { (might fail } \\
\text { on short } \\
\text { notice) } \\
\end{array}$ \\
\hline & & & & \multicolumn{3}{|c|}{ [enter emergency location(s) id\#] } \\
\hline \multirow{2}{*}{$\begin{array}{l}\text { Roads needed for } \\
\text { access to other } \\
\text { emergency } \\
\text { locations }\end{array}$} & road & \multirow{2}{*}{0} & \multirow{2}{*}{$\begin{array}{l}3 \\
\text { hours }\end{array}$} & & & \\
\hline & $\begin{array}{l}\text { associated objects and } \\
\text { systems }\end{array}$ & & & & & \\
\hline \multirow{3}{*}{ Electricity } & main cable & \multirow{3}{*}{1} & \multirow{3}{*}{$\begin{array}{c}8 \\
\text { hours }\end{array}$} & & & \\
\hline & transformer & & & & & \\
\hline & $\begin{array}{l}\text { associated objects and } \\
\text { systems }\end{array}$ & & & & & \\
\hline \multirow[b]{2}{*}{ ICT } & main fibre/ cable lines & \multirow{2}{*}{1} & \multirow{2}{*}{$\begin{array}{c}8 \\
\text { hours }\end{array}$} & & & \\
\hline & $\begin{array}{l}\text { associated objects and } \\
\text { systems }\end{array}$ & & & & & \\
\hline \multirow{2}{*}{ Process water } & pipeline network & \multirow{2}{*}{2} & \multirow{2}{*}{$\begin{array}{c}16 \\
\text { hours }\end{array}$} & & & \\
\hline & $\begin{array}{l}\text { associated objects and } \\
\text { systems }\end{array}$ & & & & & \\
\hline \multirow{2}{*}{ Natural gas } & gas pipeline & \multirow{2}{*}{3} & \multirow{2}{*}{1 day } & & & \\
\hline & $\begin{array}{l}\text { associated objects and } \\
\text { systems }\end{array}$ & & & & & \\
\hline \multirow{2}{*}{ Roads } & road & \multirow{2}{*}{3} & \multirow{2}{*}{1 day } & & & \\
\hline & $\begin{array}{l}\text { associated objects and } \\
\text { systems }\end{array}$ & & & & & \\
\hline \multirow{2}{*}{ Storm sewer } & $\begin{array}{l}\text { rainwater sewer } \\
\text { system }\end{array}$ & \multirow{2}{*}{4} & \multirow{2}{*}{2 days } & & & \\
\hline & $\begin{array}{l}\text { associated objects and } \\
\text { systems }\end{array}$ & & & & & \\
\hline \multirow[b]{2}{*}{ Waste water } & main sewer & \multirow[b]{2}{*}{5} & \multirow[b]{2}{*}{1 week } & & & \\
\hline & $\begin{array}{l}\text { associated objects and } \\
\text { systems }\end{array}$ & & & & & \\
\hline & Highly critical objects & & & & & \\
\hline & Medium critical objects & & & & & \\
\hline & Low critical objects & & & & & \\
\hline & Is not expected to occur & & & & & \\
\hline
\end{tabular}

Source: Prepared under LUBCP study.

In addition, detailed tables with measures to be implemented during and after each type of hazard have been developed for the BCP for ITOIZ, which anticipate failures of the lifeline utilities based on the risk assessment. Proposed measures which should be implemented during and after an earthquake from the ITOIZ BCP are presented in Table 4.14. 
Table 4.14 Measures during and after an earthquake

\begin{tabular}{|c|c|c|c|c|c|}
\hline No & Impact & Sub-impact & Action & Description & $\begin{array}{l}\text { Priority and time } \\
\text { objective for } \\
\text { emergency repair }\end{array}$ \\
\hline 1 & & & $\begin{array}{l}\text { Safety in ITOIZ management building using the } \\
\text { emergency response plan; when safety of management } \\
\text { is ensured continue with the rest of the BCP }\end{array}$ & & urgent \\
\hline 2 & & & Identify the effects on lifeline utilities & $\begin{array}{l}\text { Identify the effect and conduct the measures } \\
\text { related to each sub-impacted LU }\end{array}$ & urgent \\
\hline 3 & \multirow{11}{*}{$\begin{array}{l}\text { possible } \\
\text { failure of } \\
\text { road, } \\
\text { electricity, } \\
\text { ICT, natural } \\
\text { gas and } \\
\text { process } \\
\text { water } \\
\text { (directly or } \\
\text { via } \\
\text { landslides) }\end{array}$} & & Check for safety issues and instabilities & $\begin{array}{l}\text { Safety is the first course of action in these steps. } \\
\text { The instability of road conditions and natural } \\
\text { gas leaks should be checked. }\end{array}$ & urgent \\
\hline 4 & & $\begin{array}{l}\text { When electricity fails due } \\
\text { to a broken cable: }\end{array}$ & $\begin{array}{l}\text { Change the direction of power using the electricity } \\
\text { ring }\end{array}$ & $\begin{array}{l}\text { Changing the direction of the electricity ring } \\
\text { will restore electricity in general }\end{array}$ & urgent \\
\hline 5 & & \multirow{2}{*}{$\begin{array}{l}\text { When ICT cables are } \\
\text { broken: }\end{array}$} & Call TT and ask for emergency repair & & urgent \\
\hline 6 & & & Support TT for field activities & $\begin{array}{l}\text { ITOIZ should grant permit to TT before work } \\
\text { and should assist emergency services personnel }\end{array}$ & short term \\
\hline 7 & & \multirow[t]{2}{*}{$\begin{array}{l}\text { When natural gas pipes } \\
\text { are broken }\end{array}$} & $\begin{array}{l}\text { Call Igdas and ask for shut down of gas and } \\
\text { emergency repair }\end{array}$ & & urgent \\
\hline 8 & & & Support Igdas for field activities & $\begin{array}{l}\text { ITOIZ should grant permit to Igdas before work } \\
\text { and should assist emergency services personnel }\end{array}$ & short term \\
\hline 9 & & \multirow[t]{2}{*}{$\begin{array}{l}\text { When process water pipes } \\
\text { are broken: }\end{array}$} & $\begin{array}{l}\text { Repair the process water pipes when the rain has } \\
\text { stopped; if damage is large, first make an emergency } \\
\text { repair, final repairs can follow later }\end{array}$ & & short term \\
\hline 10 & & & $\begin{array}{l}\text { Bring process water directly to industries that rely on } \\
\text { water (only when repairs take longer than } 16 \text { hours) }\end{array}$ & & short term \\
\hline 11 & & $\begin{array}{l}\text { When storm sewer } \\
\text { system is broken: }\end{array}$ & $\begin{array}{l}\text { Repair the storm sewer system when the rain has } \\
\text { stopped; if damage is large, first make an emergency } \\
\text { repair, final repairs can follow later }\end{array}$ & & long term \\
\hline 12 & & \multirow[t]{2}{*}{$\begin{array}{l}\text { Difficulty of access to } \\
\text { some industries due to } \\
\text { damaged roads }\end{array}$} & Rerouting of roads & $\begin{array}{l}\text { Damaged roads might limit the access to local } \\
\text { areas of ITOIZ. The roads will be rerouted to } \\
\text { decrease traffic and maintain order in the } \\
\text { internal roads. }\end{array}$ & short term \\
\hline 13 & & & Restore the road & & long term \\
\hline
\end{tabular}




\begin{tabular}{|c|c|c|c|c|c|}
\hline No & Impact & Sub-impact & Action & Description & $\begin{array}{l}\text { Priority and time } \\
\text { objective for } \\
\text { emergency repair }\end{array}$ \\
\hline 14 & \multirow{13}{*}{$\begin{array}{l}\text { Erosion: } \\
\text { possible } \\
\text { failure of } \\
\text { road, } \\
\text { electricity, } \\
\text { ICT, natural } \\
\text { gas, storm } \\
\text { sewer and } \\
\text { process } \\
\text { water }\end{array}$} & & Check for safety issues and instabilities & $\begin{array}{l}\text { Safety is the first course of action in these steps. } \\
\text { The instability of road conditions and natural } \\
\text { gas leaks should be checked. }\end{array}$ & "urgent \\
\hline 15 & & & Identify the effects on lifeline utilities & $\begin{array}{l}\text { Identify the effect and conduct the measures } \\
\text { related to each sub-impacted LU }\end{array}$ & urgent \\
\hline 16 & & & Try to prevent further erosion by using gravel & & short term \\
\hline 17 & & $\begin{array}{l}\text { When electricity fails due } \\
\text { to a broken cable: }\end{array}$ & $\begin{array}{l}\text { Change the direction of power using the electricity } \\
\text { ring }\end{array}$ & $\begin{array}{l}\text { Changing the direction of the electricity ring } \\
\text { will restore electricity in general }\end{array}$ & urgent \\
\hline 18 & & When ICT cables are & Call TT and ask for emergency repair & & urgent \\
\hline 19 & & broken: & Support TT for field activities & $\begin{array}{l}\text { ITOIZ should grant permit to TT before work } \\
\text { and should assist emergency services personnel }\end{array}$ & short term \\
\hline 20 & & $\begin{array}{l}\text { When natural gas pipes } \\
\text { are broken }\end{array}$ & $\begin{array}{l}\text { Call Igdas and ask for shut down of gas and } \\
\text { emergency repair }\end{array}$ & & urgent \\
\hline 21 & & & Support Igdas for field activities & $\begin{array}{l}\text { ITOIZ should grant permit to Igdas before work } \\
\text { and should assist emergency services personnel }\end{array}$ & short term \\
\hline 22 & & $\begin{array}{l}\text { When process water pipes } \\
\text { are broken: }\end{array}$ & $\begin{array}{l}\text { Repair the process water pipes when the rain has } \\
\text { stopped; if damage is large, first make an emergency } \\
\text { repair, final repairs can follow later }\end{array}$ & & short term \\
\hline 23 & & & $\begin{array}{l}\text { Bring process water directly to industries that rely on } \\
\text { water (only when repairs take longer than } 16 \text { hours) }\end{array}$ & & short term \\
\hline 24 & & $\begin{array}{l}\text { When storm sewer } \\
\text { system is broken: }\end{array}$ & $\begin{array}{l}\text { Repair the storm sewer system when the rain has } \\
\text { stopped; if damage is large, first make an emergency } \\
\text { repair, final repairs can follow later }\end{array}$ & & long term \\
\hline 25 & & $\begin{array}{l}\text { Difficulty of access to } \\
\text { some industries due to } \\
\text { damaged roads }\end{array}$ & Rerouting of roads & $\begin{array}{l}\text { Damaged roads might limit the access to local } \\
\text { areas of ITOIZ. The roads will be rerouted to } \\
\text { decrease traffic and maintain order in the } \\
\text { internal roads. }\end{array}$ & short term \\
\hline 26 & & & Restore the road & & long term \\
\hline
\end{tabular}

Source: Prepared under LUBCP study. 


\section{Conclusion}

The three studies overviewed in this report demonstrate how to build resilience in critical infrastructures and services, key products and lifeline utilities in Turkey at different scales. In other words, they aim at presenting a way of mainstreaming disaster risk reduction and climate change adaptation notions into sectoral and investment planning to increase resilience at different levels, while recognizing that proposed resilience solutions and implementation strategies depend very much on the specific context (national, regional and local level and/or thematic focus).

Although the three pieces of analytical work are undertaken as pilot studies, each highlights a different aspect of normative, institutional and operational improvement areas while building resilience into critical infrastructures and assets in Turkey. In the scope of this report, primary take-aways can be clustered in two inherent pillars: (i) building resilience into infrastructures, assets and lifeline utilities, (ii) building resilience into key products and ecosystems. Considering the design, methodology and findings of the reports, the recommendations for the former would have to do with a systems approach that tackles structural and nonstructural measures, institutional coordination, data sharing and investment planning, whilst the latter would focus on governance structures and sectoral planning to safeguard preservation of ecosystems and to minimize disruptions in value chains.

In order to improve resilience of critical infrastructures and lifeline utilities, key takeaways for national and regional policymakers in Turkey, as well as the private sector are as follows:

- Critical infrastructure plays a fundamental role in the economic and social development of local, regional and national economies. The current state-of-play in Turkey is that the legislative, planning, design and operational processes driving and supporting infrastructure investments are yet to fully capture the depth and scale of disaster risk that does not only directly inform potential economic and human damages and losses, but also performance losses and competitiveness.

- Considering the concept and the implementation aspects of CI resilience are very limited in Turkey, development of a common understanding of sector specific critical infrastructure and assets resilience among decision makers and the relevant stakeholders including private sector representatives could be beneficial.

- Existing standards and policies should be updated which may result in the development of a critical infrastructure resilience framework, national BCP guidelines in which critical sectors and assets are defined, their criticality is evaluated, and sector-specific business continuity plans to improve CI resilience are produced. Turkey lacks the necessary broader regulatory framework on CI resilience covering multi-hazard risk management, including the potential adverse impacts of climate change.

- Asset level studies should be increased in number and quality to provide scalable, adaptable and component risk analysis and relevant recommendations. Furthermore, data consolidation across government institutions and information sharing and/or joint mapping can be particularly useful to enhancing stakeholder engagement and demonstrating complexity, interconnections and dependency across sectors and specific assets. 
- Non-structural risk reduction measures, such as management and operational changes, can contribute to ex-ante resilience, and they are often less costly than structural measures. Furthermore, they are inherently flexible, contributing to adaptive management in the face of future uncertainties.

- Resilience building efforts which build on the role that provincial or municipal administrations can play in localizing state-led policies, assessments and initiatives to increase resilience in organized industrial zones / industrial areas shall duly factor the operational and technical capacities and/or constraints of these sub-national stakeholders. Lack of coordination among local and central actors shall be avoided to ensure resilience building efforts remain relevant, consistent and synergetic with higher level policies. Capacity should be improved to take risk informed decision and implement investments for increase CI resilience.

- As regional authorities and local administrations continue to undertake new initiatives to assess disaster risk for enhanced preparedness and prevention, central government should play a catalyst role in facilitating access to local, regional and national level hazard data. This would lead to the development of more accurate estimations of risk which provide the basis for decision making and investment planning.

In order to improve resilience of key products, value chains and ecosystems, key takeaways for regional policymakers in Turkey as well as the private sector are as follows:

- While Turkey is on the verge of completing Basin specific hazard mapping, these should be complemented with Basin specific risk maps and climate change adaptation strategies to fully capture the estimated impacts of natural hazards and extreme weather events on key assets/products. This would require a comprehensive and efficiently coordinated strategy entrusted to multiple interlocutors in the public domain with well-defined roles and responsibilities.

- As inefficient use of groundwater exploits underground water reserves and decreases water quality, developing an action plan is key for the prevention of excessive use of groundwater and promoting awareness raising among farmers, cooperatives and asset owners/operators on water quality, efficient irrigation methods, as well as financial protection mechanisms.

- Establishment of a climate monitoring, evaluation and information system will provide increased reliability of climatic forecasts. The system will provide early warning about the phenological needs of the plant during the production process, thus, avoiding quality reduction, which in turn will yield data to inform decision-making in production lines, investment planning, profit optimization and to minimize disruptions in supply and value chains.

- Establishment of a climate change decision support system at the micro-level that would help project the impacts of climate change on farm income could provide much necessary forecasts on cash flow, savings and credit needs of small farmers and will improve farm management while complementing ex-ante disaster risk reduction and climate change mitigation measures. 


\section{References}

AKFEN Annual Report (2016). Available at: http://www.akfen.com.tr/wpcontent/uploads/2017/03/Akfen_2016_Faaliyet\%20Raporu_.pdf. (Accessed: 23 March 2018)

Birkmann Joern (2006). Measuring vulnerability to promote disaster-resilient societies: Conceptual frameworks and definitions. Institute for Environment and Human Security Journal. http://archive.unu.edu/unupress/samplechapters/1135-MeasuringVulnerabilityToNaturalHazards.pdf (Accessed: 28 May 2019).

Bozkurt, D. and Sen, O.L. (2011). Precipitation in the Anatolian Peninsula: sensitivity to increased SSTs in the surrounding seas. Clim. Dyn., 36, (3-4), 711-726

Erdik, M. (2013). Earthquake Risk in Turkey, ScienceMag, Vol. 341, Issue 6147, pp. 724-725, DOI: 10.1126/science.1238945

Fellman, T. (2012). The assessment of climate change related vulnerability in the agricultural sector: Reviewing Conceptual Frameworks. Food and Agriculture Organization. Retrieved from: http://www.fao.org/docrep/017/i3084e/i3084-04.pdf

Füssel, H.-M., Klein, R.T. (2006). Climate change vulnerability assessments: an evolution of conceptual thinking. Clim. Change 75 (3), 301-329.

GeoMaps (2011), Earthquakes in Istanbul. Available https://www.geocaching.com/geocache/GC2NNB9_earthquakes-in-istanbul?guid=11372bb4-4240-468b-a93e1816abf49021 (Accessed: May 28, 2019).

Global Facility for Disaster Reduction and Recovery (2016). Europe and Central Asia Country Risk Profiles for Floods and Earthquakes. Available at: http://documents.worldbank.org/curated/en/958801481798204368/Europe-andCentral-Asia-Country-risk-profiles-for-floods-and-earthquakes (Accessed: May 28, 2019)

Initial Communication of the Republic of Serbia to the UNFCC (2010). Available at: http://unfccc.int/resource/docs/natc/srbnc1.pdf (Accessed: May 28, 2019).

Lauwe and Riegel (2008), in Bach C., A.K. Gupta, S.S. Nair and J. Birkmann, 2013. Critical Infrastructures and Disaster Risk Reduction. National Institute of Disaster Management and Deutsche Gesellschaft für internationale Zusammenarbeit GmbH (GIZ).

Munich Re, (2019), Natural Catastrophe Review 2018, https://www.munichre.com/site/corporate/get/params_E506046347_Dattachment/1707976/munichre-naturalcatastrophes-in-2018.pdf (Accessed: March 19, 2019).

Ravindranath, N.H., Rao, S., Sharma, N., Nair, M., Gopalakrishnan, R., Rao, A.S., Malaviya, S., Tiwari, R., Sagadevan, A., Munsi, M., Krishna, N., Bala, G. (2011). Climate change vulnerability profiles for North East India. Curr. Sci. 101 (3), 384-394.

Şahinler N, Gül A. Akyol E, Yeninar H. (2008). The Effects of Global Climatic Change On Beekeeping In Turkey. Apimedica \& Apiquality 2nd International Forum.9-12 June Roma, ITALY. P:19

Sixth National Communication of the Republic of Turkey to the UNFCC (2014). Available at: https://unfccc.int/files/national_reports/non-annex_i_natcom/application/pdf/6_bildirim_eng_11_reducedfilesize.pdf (Accessed: May 28, 2019)

UNISDR (2015). Sendai Framework. Available at: https://www.unisdr.org/we/coordinate/sendai-framework (Accessed: 28 May 2019)

UNISDR (2009). UNISDR Terminology on Disaster Risk Reduction. UN International Strategy for Disaster Reduction. 
Thywissen K. (2006) , Core Terminology of Disaster Reduction: a Comparative Glossary, http://drr.upeace.org/english/documents/References/New\%20documents\%202014//Thywissen\%202006\%20Compar ative\%20glossary\%20of\%20DRR\%20terms\%20related\%20to\%20risk.pdf (Accessed 28 May 2019)

UK Cabinet Office (2010). Strategic Framework and Policy Statement on Improving the Resilience of Critical Infrastructure to Disruption from Natural Hazards, Defra Report, Cabinet Office, London. Available at: https://www.gov.uk/government/uploads/system/uploads/attachment_data/file/62504/strategic-framework.pdf. (Accessed: 31 May 2019)

World Bank (2017). High-level Critical Infrastructure Risk Assessment (CIRA) in the Region of Çukurova (Turkey).

World Bank (2018). Key Agricultural Product Risk Assessment (KAPRA). Report on the Financial Resilience of Key Agricultural Products to Climate Change

World Bank (2018). Lifeline Utility Business Continuity Plan. Developed for Tuzla industrialized zone at Istanbul

World Bank (2018). Risk assessment report. Towards development of a lifeline utility business continuity plan for Tuzla industrialized zone at Istanbul (LUBCP) 